\title{
Laboratory Investigations of Cohesionless Shear Strength in Low Confinement Environments
}

Katherine E. Winters, Oliver-Denzil S. Taylor,

August 2018

Woodman W. Berry, Amy L. Cunningham, Wesley R. Rowland,

and Mark D. Antwine
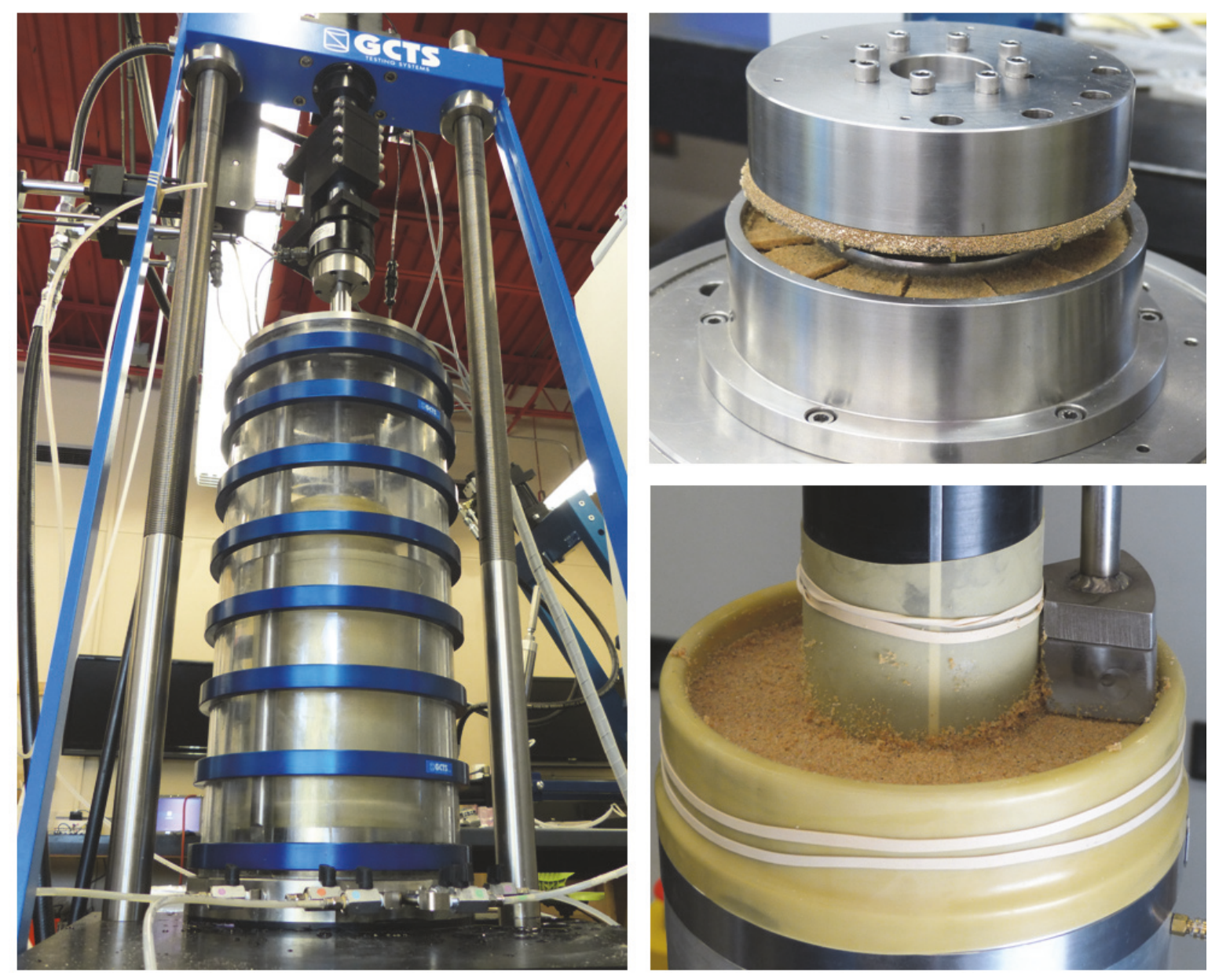
The U.S. Army Engineer Research and Development Center (ERDC) solves the nation's toughest engineering and environmental challenges. ERDC develops innovative solutions in civil and military engineering, geospatial sciences, water resources, and environmental sciences for the Army, the Department of Defense, civilian agencies, and our nation's public good. Find out more at www.erdc.usace.army.mil.

To search for other technical reports published by ERDC, visit the ERDC online library at http://acwc.sdp.sirsi.net/client/default. 


\section{Laboratory Investigations of Cohesionless Shear Strength in Low Confinement Environments}

Katherine E. Winters, Oliver-Denzil S. Taylor,

Woodman W. Berry, Amy L. Cunningham, Wesley R. Rowland, and Mark D. Antwine

Geotechnical and Structures Laboratory

U.S. Army Engineer Research and Development Center

3909 Halls Ferry Road

Vicksburg, MS 39180-6199

Final report

Approved for public release; distribution is unlimited.

Prepared for U.S. Army Corps of Engineers

Washington, DC 20314-1000

Under Project 458272, “Integrated Force Protection Against Advanced Threats” 


\section{Abstract}

In low-confining stress environments, Mohr-Coulomb failure mechanics implies that a cohesionless soil has negligible shear strength. This report presents results of total stress laboratory investigations from triaxial and simple shear loadings for three loose- to medium-dense, cohesionless materials, i.e., a poorly-graded sand (SP), a silty sand (SM), and a silt (ML), at confining pressures ranging from zero to $1,000 \mathrm{kPa}$, as well as cyclic ring shear testing of the SP material at confining pressures from 10 to $100 \mathrm{kPa}$. All materials exhibited shear strengths and stress paths in excess of expected failure surfaces at confining pressures under $100 \mathrm{kPa}$. The data indicate that cohesionless soils exhibit significant soil fabric strength characteristics that are not captured by the standard internal friction angle definition, as evidenced by the shear stress intercept of the trendlines relating shear strength and confining pressure. Under low confinement, the continuum fabric dominates the angle of the Mohr envelope. The significant difference in the Mohr envelope shape illustrates that the internal fabric's ability to resist different loading mechanisms cannot be assumed by a linear approximation.

DISCLAIMER: The contents of this report are not to be used for advertising, publication, or promotional purposes. Citation of trade names does not constitute an official endorsement or approval of the use of such commercial products. All product names and trademarks cited are the property of their respective owners. The findings of this report are not to be construed as an official Department of the Army position unless so designated by other authorized documents. 


\section{Contents}

Abstract.................................................................................................................................. ii

Figures and Tables..............................................................................................................iv

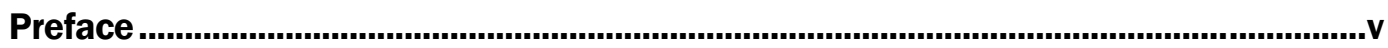

Unit Conversion Factors....................................................................................................

1 Introduction ................................................................................................ 1

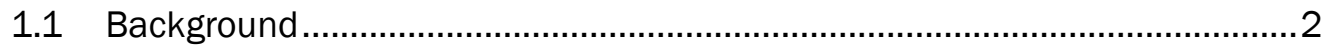

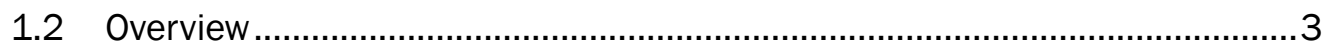

1.2.1 Chapter 2: Experimentation ....................................................................... 3

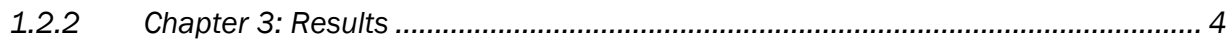

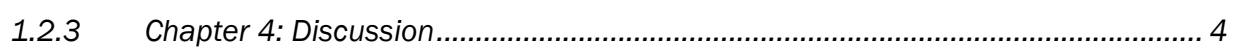

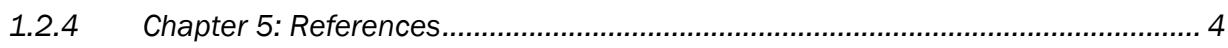

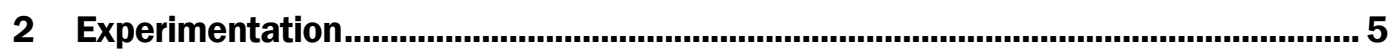

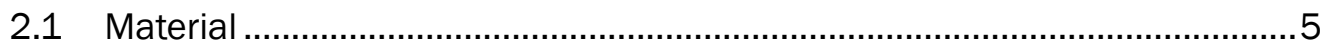

2.2 Specimen preparation.............................................................................. 6

2.3 Triaxial specimen preparation and testing protocol ....................................6

2.4 Simple shear specimen preparation and testing protocol ..............................8

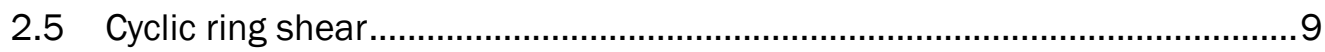

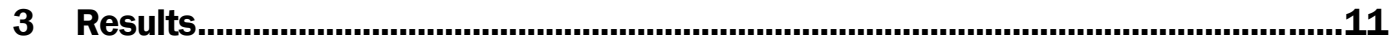

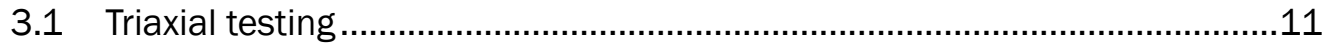

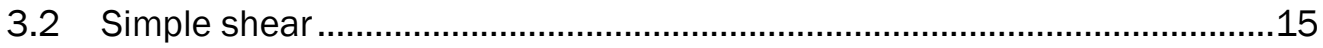

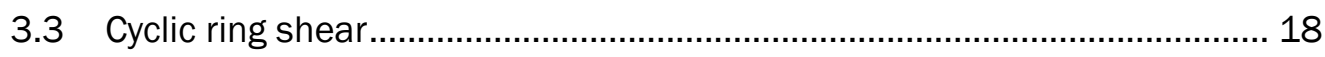

4 Discussion ................................................................................................................21

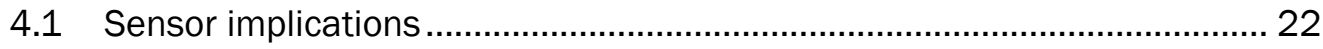

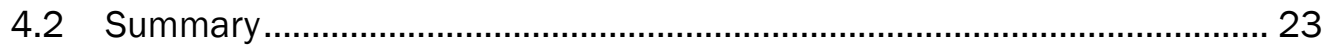

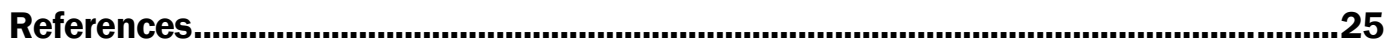

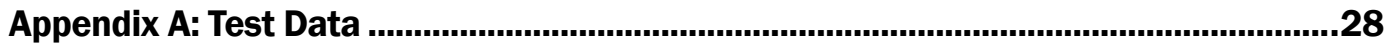

\section{Report Documentation Page}




\section{Figures and Tables}

\section{Figures}

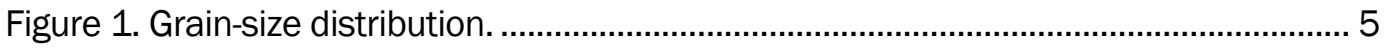

Figure 2. Typical UDTX test on SM specimen before (a) and after (b) testing..................... 7

Figure 3. Typical UDSS specimen before (a) and after (b) testing..................................... 9

Figure 4. Typical $A C U_{C Y C, R S}$ specimen after construction (a) and during saturation

(b).

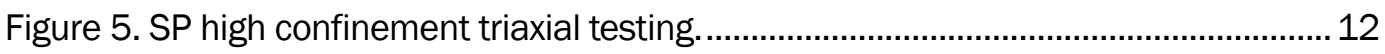

Figure 6. SM high confinement triaxial testing........................................................... 12

Figure 7. ML high confinement triaxial testing................................................................ 13

Figure 8. SP triaxial results. Dashed line indicates the theoretical failure plane, and the solid line indicates the observational failure plane. ............................................. 14

Figure 9. SM triaxial results. Dashed line indicates the theoretical failure plane, and the solid line indicates the observational failure plane.

Figure 10. ML triaxial results. Dashed line indicates the theoretical failure plane, and the solid line indicates the observational failure plane. ............................................. 15

Figure 11. SP low confinement simple shear results. ..................................................... 17

Figure 12. SM low confinement simple shear results. ....................................................... 17

Figure 13. ML low confinement simple shear results....................................................... 18

Figure 14. SP cyclic ring-shear shear stress and cyclic strain at failure........................... 19

Figure 15. SP cyclic ring-shear shear stress and cyclic strain at critical state...................20

\section{Tables}

Table 1. Triaxial testing summary for near-surface UD and ICD testing............................ 11

Table 2. Simple shear testing summary for near-surface UD and ICD testing................... 16

Table 3. SP cyclic ring shear testing summary. …….......................................................... 18 


\section{Preface}

This study was conducted for the U.S. Army Corps of Engineers under U.S. Army Military Engineering "Integrated Force Protection Against Advanced Threats” Program. The project manager was Dr. Michael I. Hammons.

The work was performed by the Structural Engineering Branch (StEB) of the Geosciences and Structures Division (GSD), U.S. Army Engineer Research and Development Center, Geotechnical and Structures Laboratory (ERDC-GSL). At the time of publication, Mr. Charles W. Ertle was Chief, StEB; Mr. James L. Davis was Chief, GSD; and Ms. Pamela G. Kinnebrew was the Technical Director for Military Engineering. The Deputy Director of ERDC-GSL was Dr. William P. Grogan, and the Director was Mr. Bartley P. Durst.

COL Ivan P. Beckman was the Commander of ERDC, and Dr. David W. Pittman was the Director. 


\section{Unit Conversion Factors}

\begin{tabular}{|l|c|l|}
\hline English - Multiply & By & To Obtain - Metric \\
\hline cubic feet & 0.02831685 & cubic meters \\
\hline cubic inches & $1.6387064 \mathrm{E}-05$ & cubic meters \\
\hline cubic yards & 0.7645549 & cubic meters \\
\hline feet & 0.3048 & meters \\
\hline pounds (force) per foot & 14.59390 & newtons per meter \\
\hline pounds (force) per inch & 175.1268 & newtons per meter \\
\hline pounds (mass) & 0.45359237 & kilograms \\
\hline pounds (mass) per cubic foot & 16.01846 & kilograms per cubic meter \\
\hline pounds (mass) per cubic inch & $2.757990 \mathrm{E}+04$ & kilograms per cubic meter \\
\hline yards & 0.9144 & meters \\
\hline
\end{tabular}




\section{Introduction}

Understanding the true behavior of cohesionless soils immediately impacts the fields of internal erosion prediction, surficial sloughing of dams and levee slopes, wave propagation, geo-sensor coupling, and geoenvironmental contamination and remediation designs. Laboratory experimentation on cohesionless soil fabric behavior in low-to-zero vertical confining pressure environments (representing the upper one meter) relies on the use of effective stress principles to infer behavior (Fannin et al. 2005; Huang et al. 2015; Lancelot et al. 2006). However, effective-stress-based laboratory tests are not indicative of low-confining pressure in situ environments. Mohr-Coulomb mechanics defines a continuum's shear strength, $\tau$, as a function of the normal effective stress along the failure plane, $\sigma f^{2}$.

$$
\tau=c^{\prime}+\sigma_{f}^{\prime} \tan \left(\phi_{f}^{\prime}\right)
$$

For cohesionless materials, the $c$ ' parameter is assumed to be zero, and the internal friction angle, $\phi f$ ', is then determined through a best-fit failure envelope anchored around the origin of the Mohr diagram ( $\tau$ vs. $\sigma$ graph). In low-confining stress environments, this implies that a cohesionless soil has negligible shear strength. Ho wever, confining pressure is not the only factor that contributes to a soil's ability to resist shear. The structure and fabric of the soil must also be explicitly accounted for. The term soil continuum fabric is defined as the inclusion of both the soil fabric and structure as defined by Mitchell and Soga (2005) as well as the sum of the continuum granular contact forces (Koustuvee et al. 2014) that govern a specimen's strength and volumetric behavior. The validity of Equation 1 then relies on the standard definitions of $\phi f^{\prime}$ and $c^{\prime}$. For most geotechnical problems, Equation 1 yields relatively accurate approximations due to moderate to high-confining stresses. However, the failure plane suggested by Mohr-Coulomb mechanics may not be the actual failure plane upon which shear strains concentrate under near-surface environments. Herein, the terms "theoretical failure plane" and "observational failure plane" are used to signify the expected failure plane following traditional MohrCoulomb mechanics and the failure plane calculated from the test data, respectively. 
To illustrate the significance of the conservatism of Mohr-Coulomb mechanics and the effects of soil continuum fabric on the continuum shear strength within low-confining pressure environments, this report presents results from total stress laboratory investigations from triaxial and simple shear loadings for three cohesionless materials, i.e., a loose-to-mediumdense poorly-graded sand (SP), a silty sand (SM), and a silt (ML), and cyclic shear loading of poorly-graded sand (SP).

\subsection{Background}

Seismic arrays are utilized globally to persistently monitor subsurface events, spanning a variety of technologies from permanently emplaced borehole seismometer networks to monitor earthquakes (Chapman 2013), to mobile and temporarily deployed oil and gas land-streamer geophone survey rigs (Tsoflias et al. 2006). Through careful analysis, these seismic arrays can forensically investigate events of interest, such as discrimination of nuclear and chemical explosions (Stump et al. 1999), pipeline explosions (Koper et al. 2003), and even military events (Bonner et al. 2013). However, in order to effectively reconstruct source properties such as duration, spatial length, strength or dominant period, and yield, receiver-side effects must be properly assessed for each deployment. The emplacement location of these sensors balances the need for signal identification and logistics. Historically, the geophysical sensor is placed in a relatively quiet location to allow maximum signal detection, and calibration surveys are performed to assess quality of the environment. Ideally, seismic sensors are emplaced in a hard rock environment with a low-noise field, ensuring the maximum possible signal-to-noise ratio. The ability to discriminate between triggering seismic sources, e.g., person(s), animals, vehicular type(s), etc., and their distance/direction from the receiver is necessary for persistent monitoring geophysical instrumentation, no matter the time scale of deployment.

Generally, arrays can be considered a suite of instruments subject to an integrated processing scheme. The design of a given array is situated to meet one or more objectives, such as the detection of low-magnitude events or the location of events. The advantages inherent in using arrays include the separation of the signal from the local noise, the improvement of the signal-to-noise ratio for small events, and the determination of phase velocity and back-azimuth or direction of arrival. Therefore, arrays are designed for the optimum detection of signals with sufficient reliability to enhance weak signals (Ringdal and Husebye 1982; Mykkeltveit et al. 
1990). The amplitude of observed signals is directly dependent on the absorption loss over the propagation path. It is difficult to measure absorption in the field because the relationship between laboratory measurements and observations in the field is not clearly defined (Sheriff and Geldart 1995).

Ideally, seismic arrays are situated in a medium that is not sensitive to low confinement conditions, e.g., the bedrock installation of earthquake monitoring networks, thereby simplifying the contribution of propagation path effects on source identification. However, operational arrays with deployments spanning days to months do not have the luxury of avoiding inconvenient meteorological events, nor are they able to be situated in an ideal medium due to logistical constraints. Therefore, rather than being placed in rock, seismic sensors may be placed in near-surface soil, and therefore, the propagation media are neither hard rock nor an isotropic Newtonian fluid (Aki and Richards 1980). For targeted temporary persistent monitoring situations, careful site selection is usually not possible, and the target of interest dictates sensor location. Currently, sensors are calibrated onsite for specific signals of interest. If the site conditions change or signals of interest change, extensive retraining or tuning may be required to avoid misclassification of signals or errors in localization. By understanding the near-surface attributes and characterizing how they change in different geologies, seismic signals may be predicted before installation. Therefore, the low-confinement soil continuum fabric behaviors play a critical role in the performance and signal processing of these temporary persistent monitoring arrays.

\subsection{Overview}

The purpose of this research is to show that that cohesionless soils exhibit significant soil fabric strength characteristics that are not captured by the standard internal friction angle definition.

\subsubsection{Chapter 2: Experimentation}

Chapter 2 begins with a description of the three cohesionless materials tested in this study: a poorly-graded sand (SP), a silty sand (SM), and a silt (ML). Specimen preparation methods are then detailed, as well as triaxial, simple shear, and cyclic ring shear testing protocols for confining pressures ranging from zero to $1,000 \mathrm{kPa}$. Three repetitions of each 
triaxial and simple shear test condition were conducted, while 10 repetitions of each cyclic ring shear test were conducted.

\subsubsection{Chapter 3: Results}

Chapter 3 presents the analysis methods and results for each testing type. Average values are listed for each test condition. In total, 63 triaxial tests, 81 simple shear tests, and 50 cyclic ring shear tests were conducted. All materials exhibited shear strengths and stress paths in excess of expected failure surfaces at confining pressures under $100 \mathrm{kPa}$.

\subsubsection{Chapter 4: Discussion}

Chapter 4 contains a discussion of the implications of the findings, namely that the data imply that the governing mechanics in the near-surface environment are not simply controlled by the confining pressures and are more complex than approximated by Mohr-Coulomb mechanics. In all loading cases, there is a $y$-intercept ( $c^{\prime}$ ) suggesting that even a non-plastic cohesionless material will retain some degree of internal structure even without confining pressures.

Of particular importance is the impact to sensor work as near-surface seismic sensors are placed within low-confinement environments. These data further imply departures from expected modulus values that impact signal-processing calculations.

The chapter concludes with a summary of the research findings.

\subsubsection{Chapter 5: References}

Chapter 5 contains the references cited within this technical report. 


\section{Experimentation}

\subsection{Material}

The grain-size distributions of the cohesionless materials in this study are shown in Figure 1.

Figure 1. Grain-size distribution.

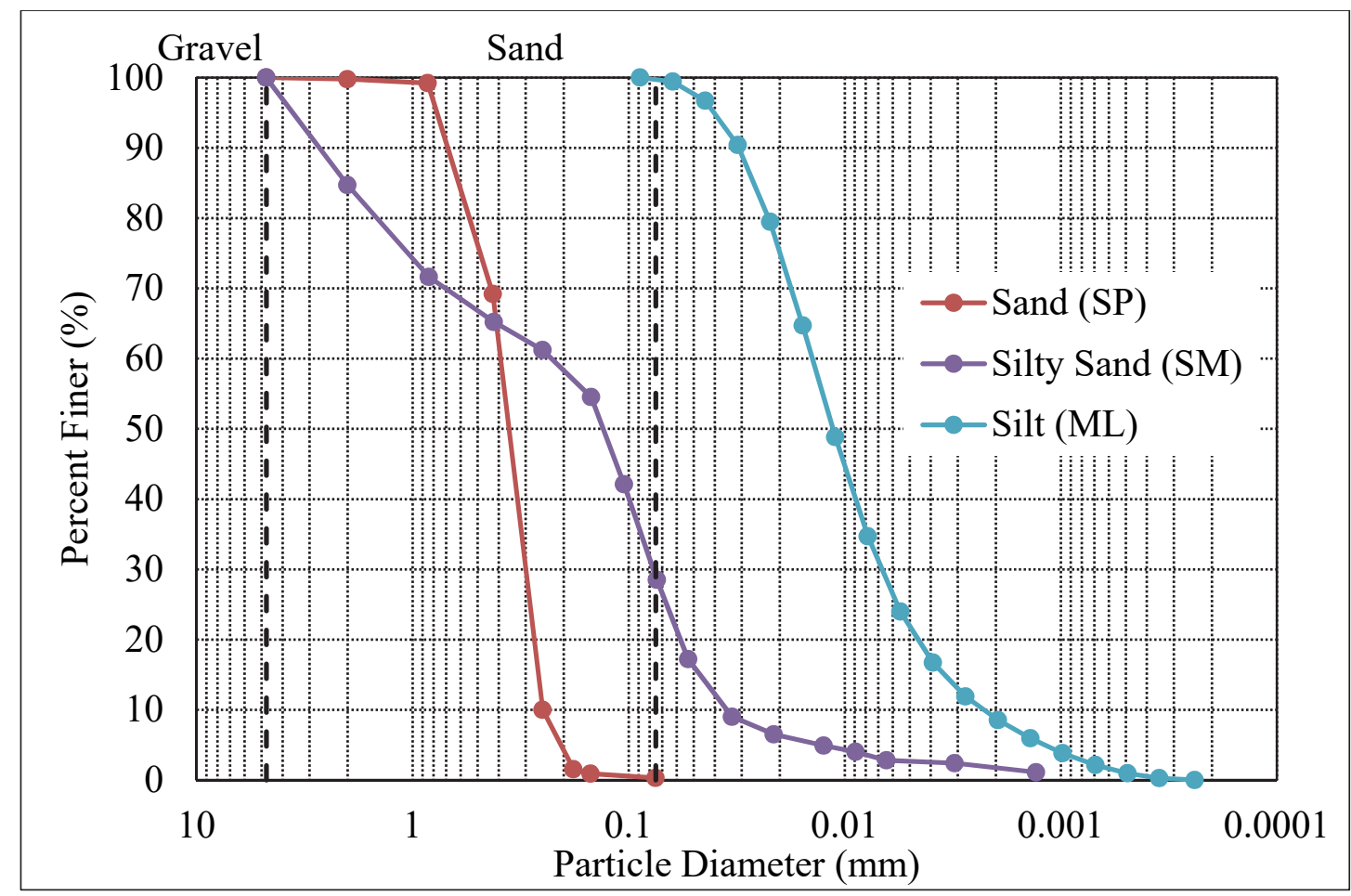

The sand is a washed, uniform, medium-to-fine beach sand (SP). The material is poorly graded with 90 percent of the material between 0.25 and $0.85 \mathrm{~mm}$ in diameter. The Coefficient of Uniformity is 1.52, reflecting the dominance of the No. 40 and No. 60 sieves in the grain-size distributions. The Coefficient of Curvature is 1.12. The specific gravity is 2.70 .

The silty sand is a cohesionless engineered silty sand (SM) representative of known soils at Aberdeen Proving Grounds, MD. The soil consisted of 71.5 percent sand, 26.8 percent silt, and 1.7 percent clay. Atterberg limits tests classify the material as non-plastic (ASTM Standard D4318) (ASTM International 2010). The specific gravity is 2.78 . High-pressure triaxial testing (confining pressures of 2.5 MPa to $200 \mathrm{MPa}$ ) of this material can be found in Graham et al. (2014). 
The silt is a blended silt (ML) consisting of three natural Rhode Island silts. The liquid limit could not be determined rendering these silts as nonplastic (ASTM Standard D4318) (ASTM International 2010; Taylor 2011). A negligible presence of organic material was detected. The specific gravity of the silt is 2.75. Further information on this silt can be found in Taylor (2011).

\subsection{Specimen preparation}

Consistently tight tolerances during sample preparation are crucial to both replicate in-situ field conditions and ensure continuity across multiple reconstituted laboratory samples (Bradshaw and Baxter 2007; Taylor 2011; Taylor et al. 2016). Samples were reconstituted using a modified moist tamping procedure resulting in less than 2 percent difference in sample density and moisture content (Taylor 2011; Taylor et al. 2012; Taylor et al. 2016). These tolerances are stricter than ASTM laboratory procedures, thereby yielding highly repeatable samples with no appreciable fabric variance from reconstitution between specimens. Thus, observed effects at low-to-zero confining pressures are representative of fabric behavior and not artifacts of variation in sample preparation.

All samples were constructed at loose-to-medium density and dry of the optimal moisture content in accordance with Taylor et al. (2016), with modifications for UD (unconsolidated drained) and ICD (isotropic consolidated drained) specimens tested at $15-\mathrm{kPa}$ confining pressure (Berry et al. 2018). Sand specimens were compacted to a density of $1.65 \mathrm{~g} / \mathrm{cc}$ and water content of 5.66 percent. Silty sand specimens were compacted to a density of $1.76 \mathrm{~g} / \mathrm{cc}$ and water content of 10.5 percent. Silt specimens were compacted to a density of $1.68 \mathrm{~g} / \mathrm{cc}$ and water content of 12.8 percent.

Specimens were tested under isotropic consolidated-drained simple shear (ICDss), unconsolidated-drained simple shear (UDss), isotropic consolidated-drained triaxial ( $\mathrm{ICD}_{\mathrm{TX}}$ ), and unconsolidated-drained triaxial (UDTx) conditions with confining pressures between o $\mathrm{kPa}$ and 1,000 $\mathrm{kPa}$.

\subsection{Triaxial specimen preparation and testing protocol}

Triaxial test specimens measured $71.9 \mathrm{~mm}$ in diameter by $145.0 \mathrm{~mm}$ in height. After compaction, the height was measured and the density calculated to ensure the target density was obtained. No vacuum pressure 
was applied to specimens tested at or below $15-\mathrm{kPa}$ confining pressure to prevent artificial granular movement.

- For UDTX specimens: After the membrane was secured to the top platen, the mold was removed. The test cell was not used. The specimen valve was opened to the atmosphere creating drained conditions. Previous research showed no appreciable difference in shear strength for UD ${ }_{\text {Tx }}$ specimens tested both with and without a 0.3mm-thick latex membrane (Winters et al. 2016), so the membrane was left in place for ease of UDTX testing for the sand and removed for the silty sand and silt.

All samples followed near-surface testing protocols (Berry et al. 2018) under an axial loading strain rate of 0.25 percent $/ \mathrm{min}$. Three repetitions of each test condition were conducted for a total of 21 tests per soil type. Figure 2 shows a typical UDTх test specimen without a membrane before and after testing.

Figure 2. Typical UDTX test on SM specimen before (a) and after (b) testing.
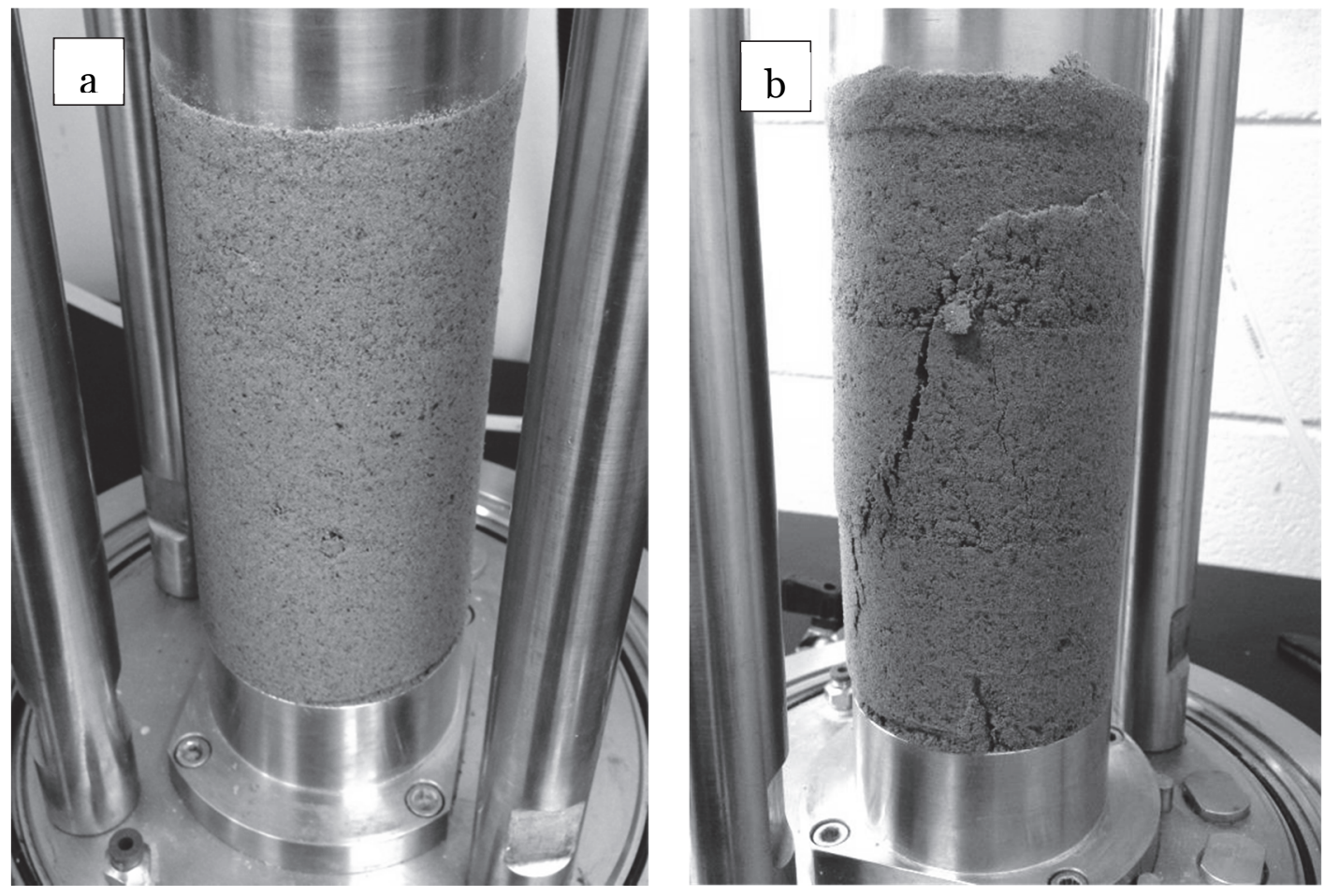


\subsection{Simple shear specimen preparation and testing protocol}

Simple shear specimens measured $72.9 \mathrm{~mm}$ in diameter by $32.0 \mathrm{~mm}$ in height. Simple shear specimens were constructed in one layer in accordance with Taylor et al. (2016) and Berry et al. (2018).

- For ICDss specimens tested at 25-kPa confining pressure or greater: A vacuum was applied to the sample, and the mold was removed. The test cell was secured and filled with water. A cell pressure of $25 \mathrm{kPa}$ was applied, the vacuum was released opening the specimen to the atmosphere and creating drained conditions, and the test confining pressure was applied. A 5-kPa vertical seating pressure was applied.

- For ICDss specimens tested at $15 \mathrm{kPa}$ confining pressure or less: No vacuum was applied to the sample. The mold was removed. The test cell was secured and filled with water. The specimen valve was opened to the atmosphere creating drained conditions, and the test confining pressure was applied. A 5-kPa vertical seating pressure was applied.

- For UDss specimens: No vacuum was applied to the sample. After the top platen was brought into contact with the specimen, the mold was removed. The test cell was not used. Samples were constructed using either a latex membrane or wax paper to line the construction mold. After the top platen was brought into contact with the specimen, the mold was removed, and the latex membrane or wax paper was carefully cut from the sample. Latex membranes were left in place for ease of UDss testing for the SP and removed for the SM and ML materials. One series of tests was conducted with a 5 -kPa seating pressure and another series of tests at 2-kPa seating pressure to investigate the impact of the seating load on shear strength.

All samples were sheared at a strain rate of 0.25 percent/min (Berry et al. 2018). Three repetitions of each test condition were conducted for a total of 27 simple shear tests per soil type. Figure 3 shows a typical UDss test specimen without a membrane before and after testing. 
Figure 3. Typical UDSS specimen before (a) and after (b) testing.
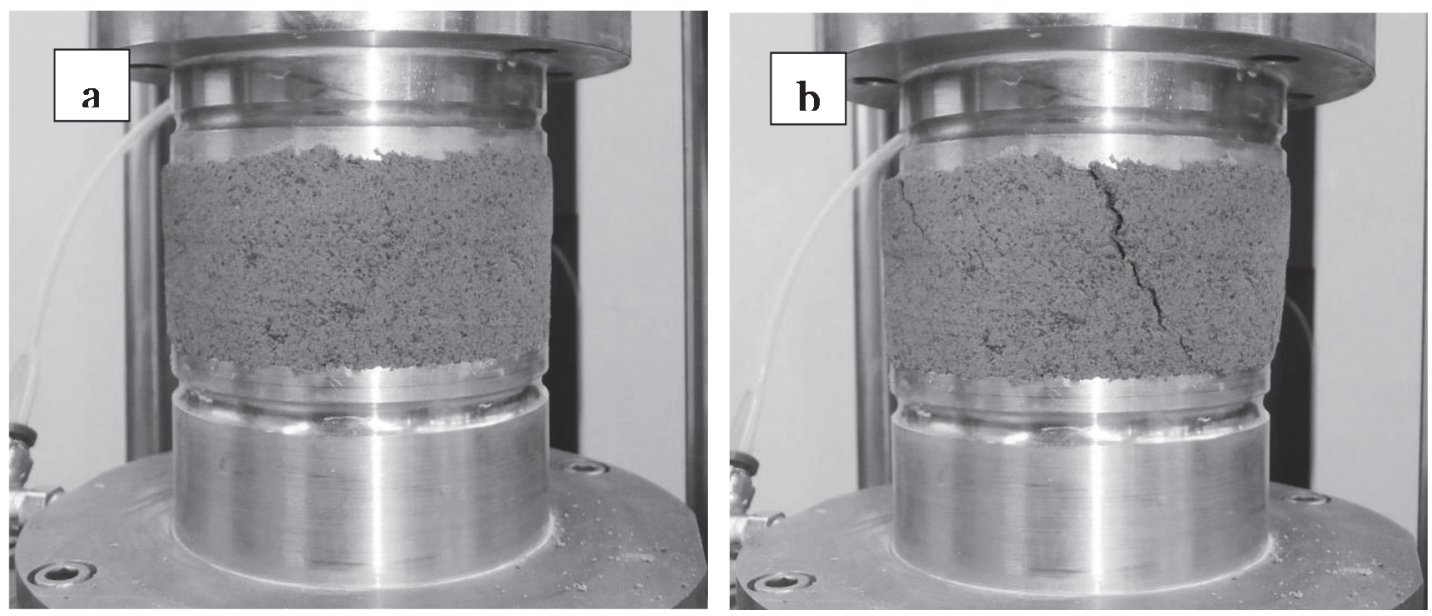

\subsection{Cyclic ring shear}

Cyclic ring shear specimens measured $150 \mathrm{~mm}$ in outer diameter, $100 \mathrm{~mm}$ in inner diameter, and $25 \mathrm{~mm}$ in height. Ring shear specimens were constructed in one layer in accordance with Taylor et al. (2016) and Berry et al. (2018).

After specimen construction and application of a seating load, the specimen was saturated in a water bath. The confining pressure was then increased to the test confining pressure. The specimen was held at the test confining pressure for $30 \mathrm{~min}$ before shearing.

During shearing, the confining pressure was held constant while the specimen was sheared using a sine wave form set to an amplitude of $2.5 \mathrm{~mm}$ and a frequency of 0.5 for a duration of 10 cycles (Berry et al. 2018). Ten repetitions of each test condition were conducted for a total of 50 cyclic ring shear tests on SP soil. Figure 4 shows a typical saturated, anisotropic-consolidated undrained cyclic ring shear (ACUCYC,RS) test specimen after construction (a) and during saturation (b). 
Figure 4. Typical $A C U_{C Y C, R S}$ specimen after construction (a) and during saturation (b).
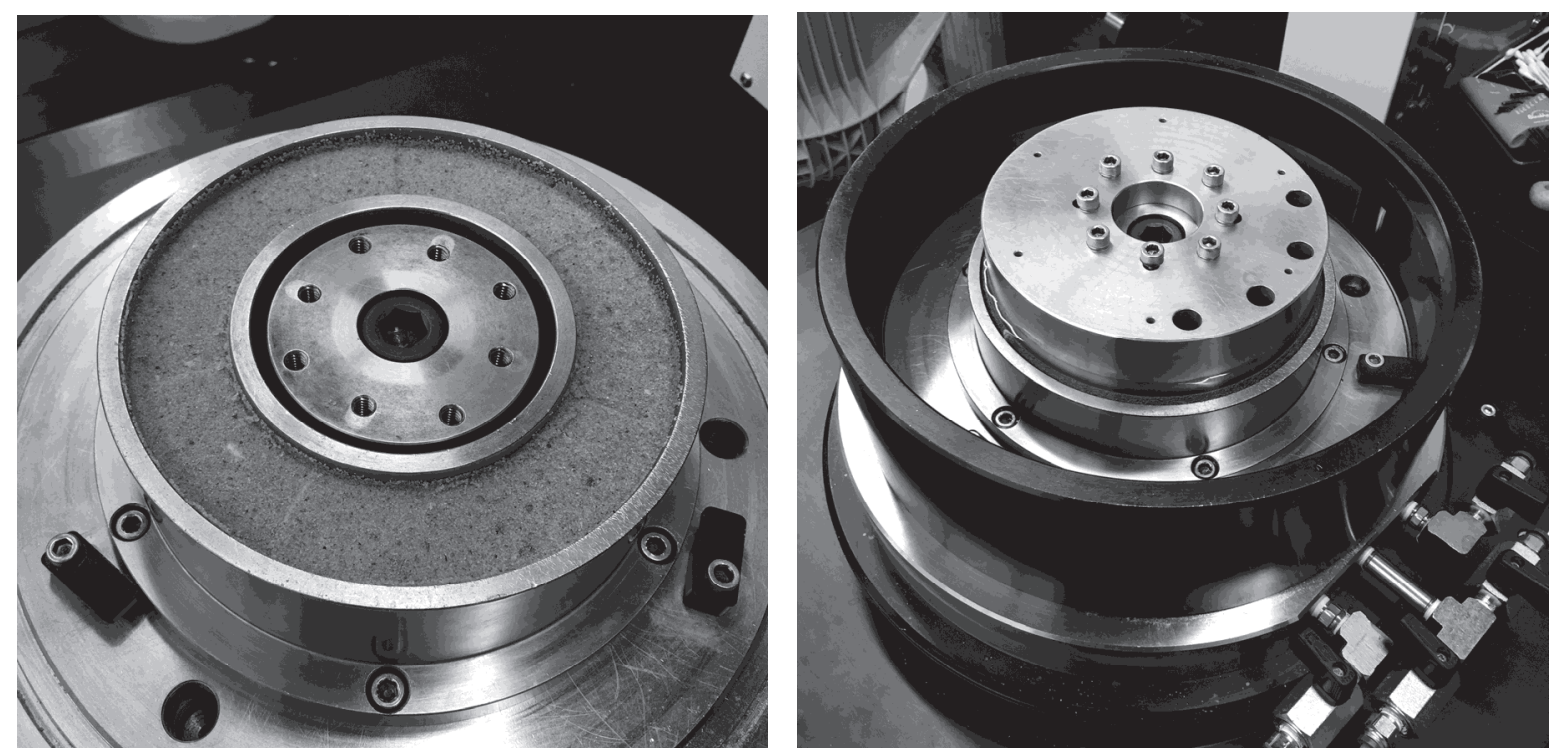


\section{Results}

The following sections contain a summary of the results of triaxial, simple shear, and cyclic ring shear testing. Details of each test are provided in the appendix.

\subsection{Triaxial testing}

Table 1 lists the confining pressures and average shear stresses at failure from the triaxial tests conducted for this study, for a total of 63 triaxial tests. Triaxial failure strength was determined at the point of maximum deviator stress.

Table 1. Triaxial testing summary for near-surface UD and ICD testing.

\begin{tabular}{|l|l|l|l|}
\hline & \multicolumn{3}{|c|}{$\begin{array}{c}\text { Average shear stress at } \\
\text { failure, } \mathrm{kPa}(\mathrm{n}=3)\end{array}$} \\
\hline Confining pressure & $\mathrm{SP}$ & $\mathrm{SM}$ & $\mathrm{ML}$ \\
\hline UD & 35 & 27 & 102 \\
\hline ICD $15 \mathrm{kPa}$ & 74 & 87 & 158 \\
\hline ICD $25 \mathrm{kPa}$ & 109 & 121 & 201 \\
\hline ICD $50 \mathrm{kPa}$ & 216 & 177 & 247 \\
\hline ICD $100 \mathrm{kPa}$ & 403 & 327 & 377 \\
\hline ICD $500 \mathrm{kPa}$ & 1560 & 1371 & 1225 \\
\hline ICD $1000 \mathrm{kPa}$ & 2304 & 2170 & 2018 \\
\hline
\end{tabular}

The expected Mohr-Coulomb failure plane for each material was defined using test results of ICDTx tests conducted with confining pressures of 100, 500 , and 1,000 kPa, as shown in Figure 5 - Figure 7. A trendline was fit to the test results in $\mathrm{p}-\mathrm{q}$ space assuming a cohesion intercept of zero, consistent with assumptions for granular materials (Lambe and Whitman 1969). These trendlines follow the form shown in Equation 2, with $m$ set to zero (Das 2002).

$$
q=m+p * \tan (\alpha)
$$

Which can be related back to traditional $\phi$ and $c$ values of the form $\tau=c+$ $\sigma * \tan (\phi)$ using Equations 3 and 4 (Das 2002). 


$$
\begin{aligned}
& \tan (\alpha)=\sin (\phi) \\
& m=c * \cos (\phi)
\end{aligned}
$$

The resulting friction angle, $\phi_{f}$, was used for the subsequent analysis of the low-confinement test results.

Figure 5. SP high confinement triaxial testing.

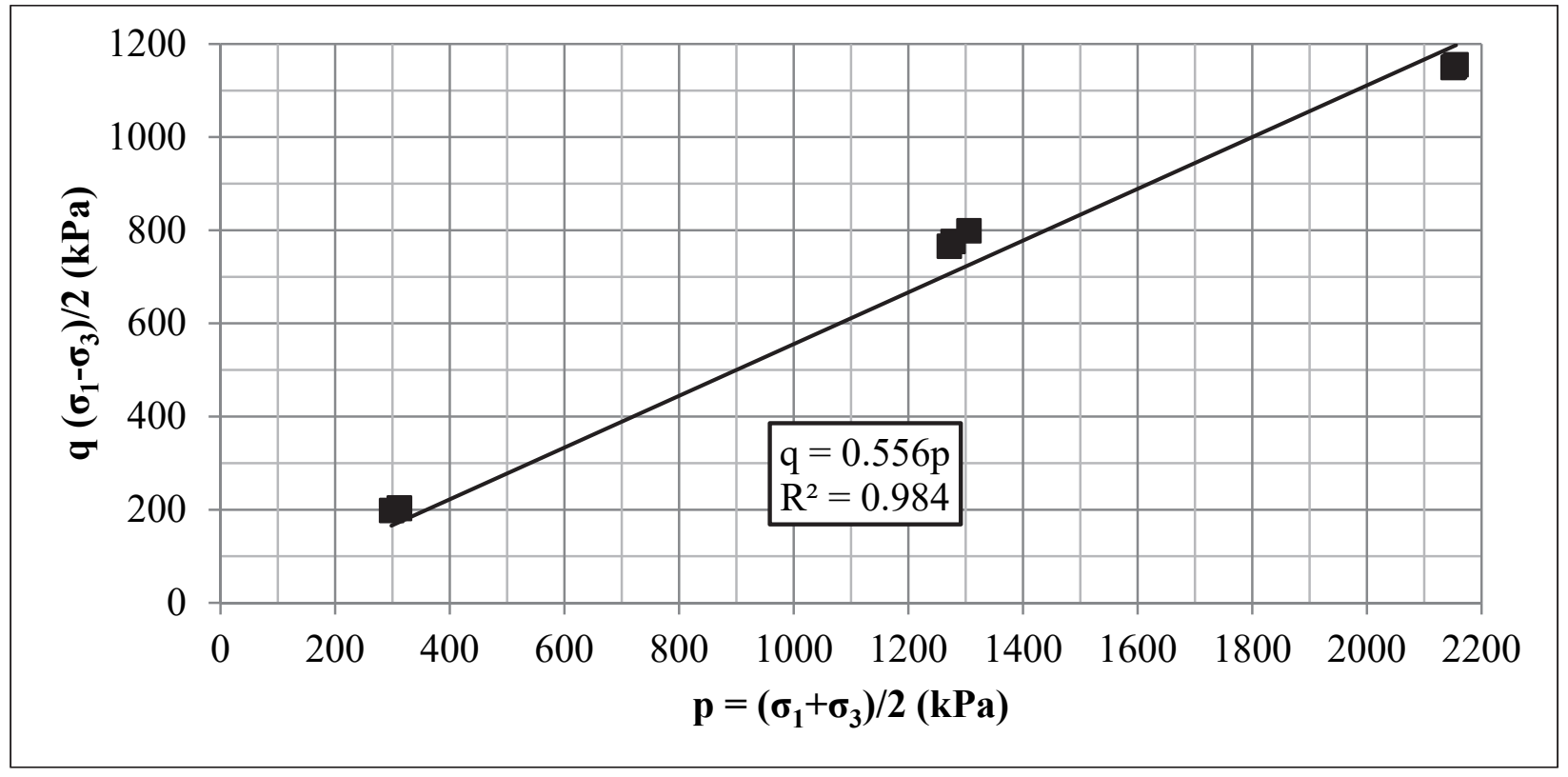

Figure 6. SM high confinement triaxial testing.

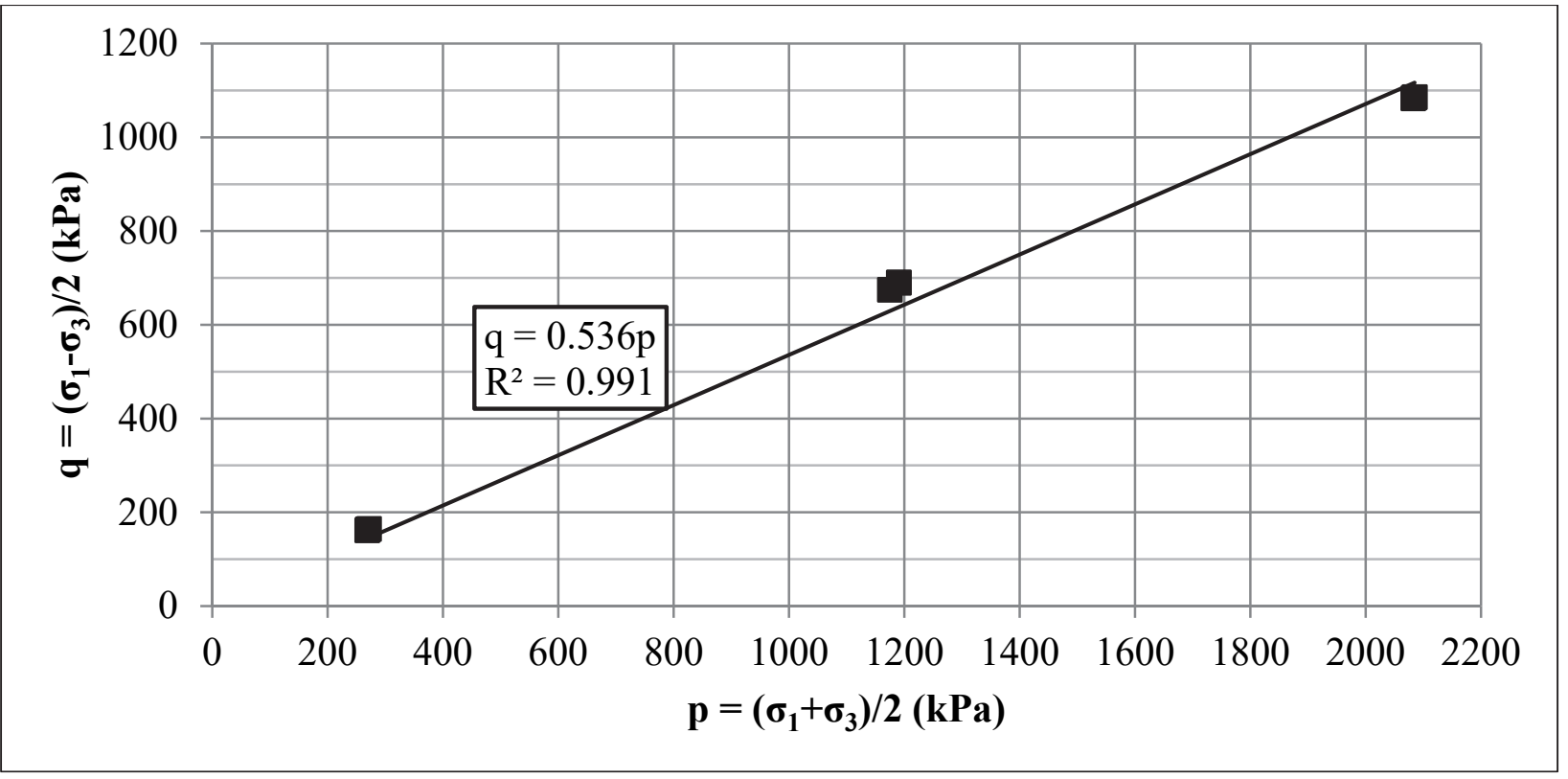


Figure 7. ML high confinement triaxial testing.

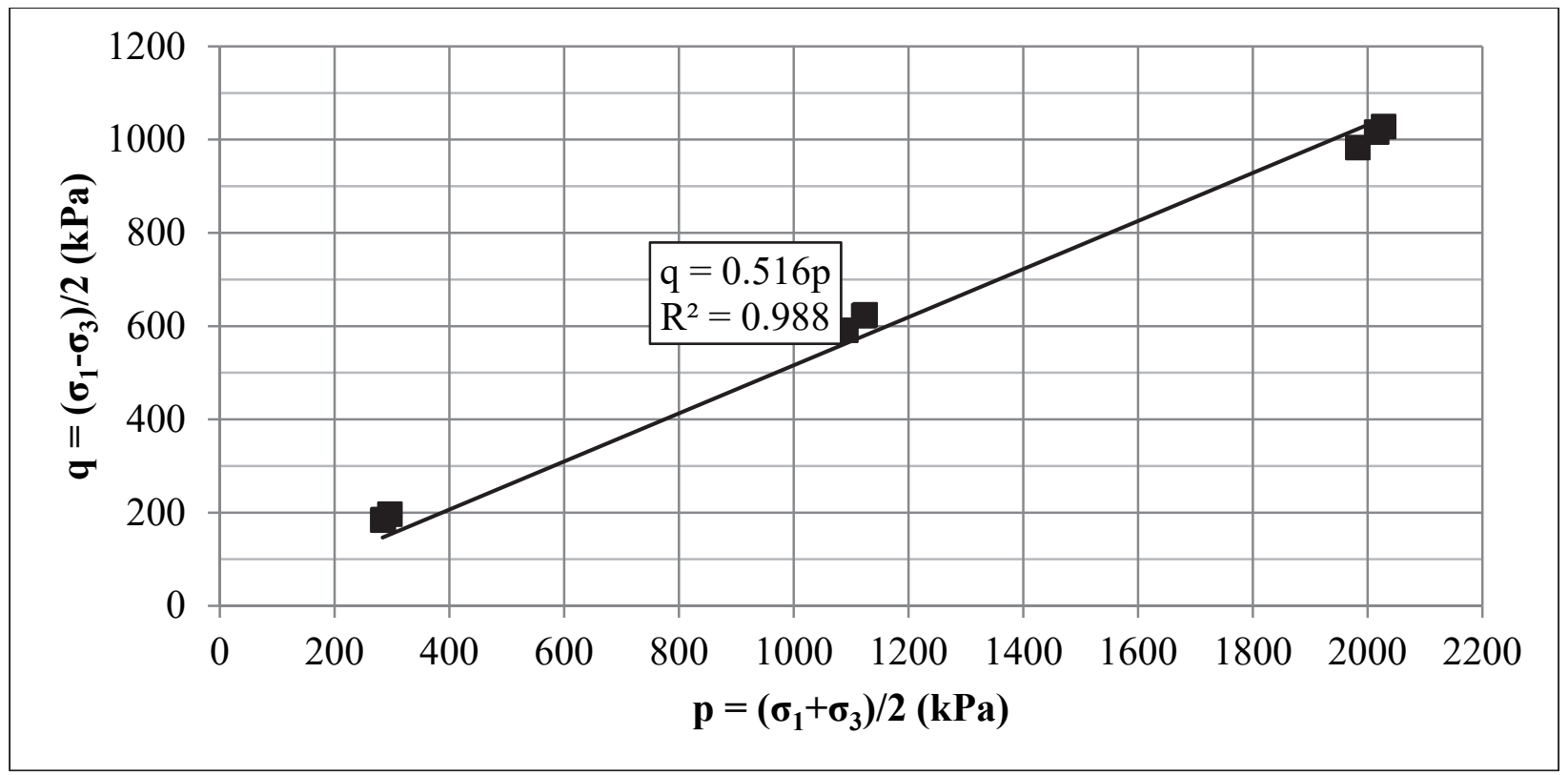

Figure 8 - Figure 10show the results of triaxial testing in p-q space for tests up to and including $50-\mathrm{kPa}$ confining pressure. It can be seen that results of all of the triaxial tests plot above their respective theoretical failure envelopes. The dashed line represents the theoretical failure envelope expected from higher-confinement testing: $\phi_{f}=33.8^{\circ}$ for SP, $\phi_{f}=32.4^{\circ}$ for $\mathrm{SM}$, and $\phi_{f}=31.1^{\circ}$ for ML. For each material, the test results under $50 \mathrm{kPa}$ can better be represented by a steeper friction angle $\left(\phi_{f},\right)$ and non-zero intercept (c) as calculated from Equations 3 and 4:

- $\mathrm{SP}-38.9^{\circ}$ line with a $6.05 \mathrm{kPa}$ intercept.

- SM- $35.4^{\circ}$ line with a $7.17 \mathrm{kPa}$ intercept.

- ML- $36.5^{\circ}$ line with a $27.2 \mathrm{kPa}$ intercept. 
Figure 8. SP triaxial results. Dashed line indicates the theoretical failure plane, and the solid line indicates the observational failure plane.

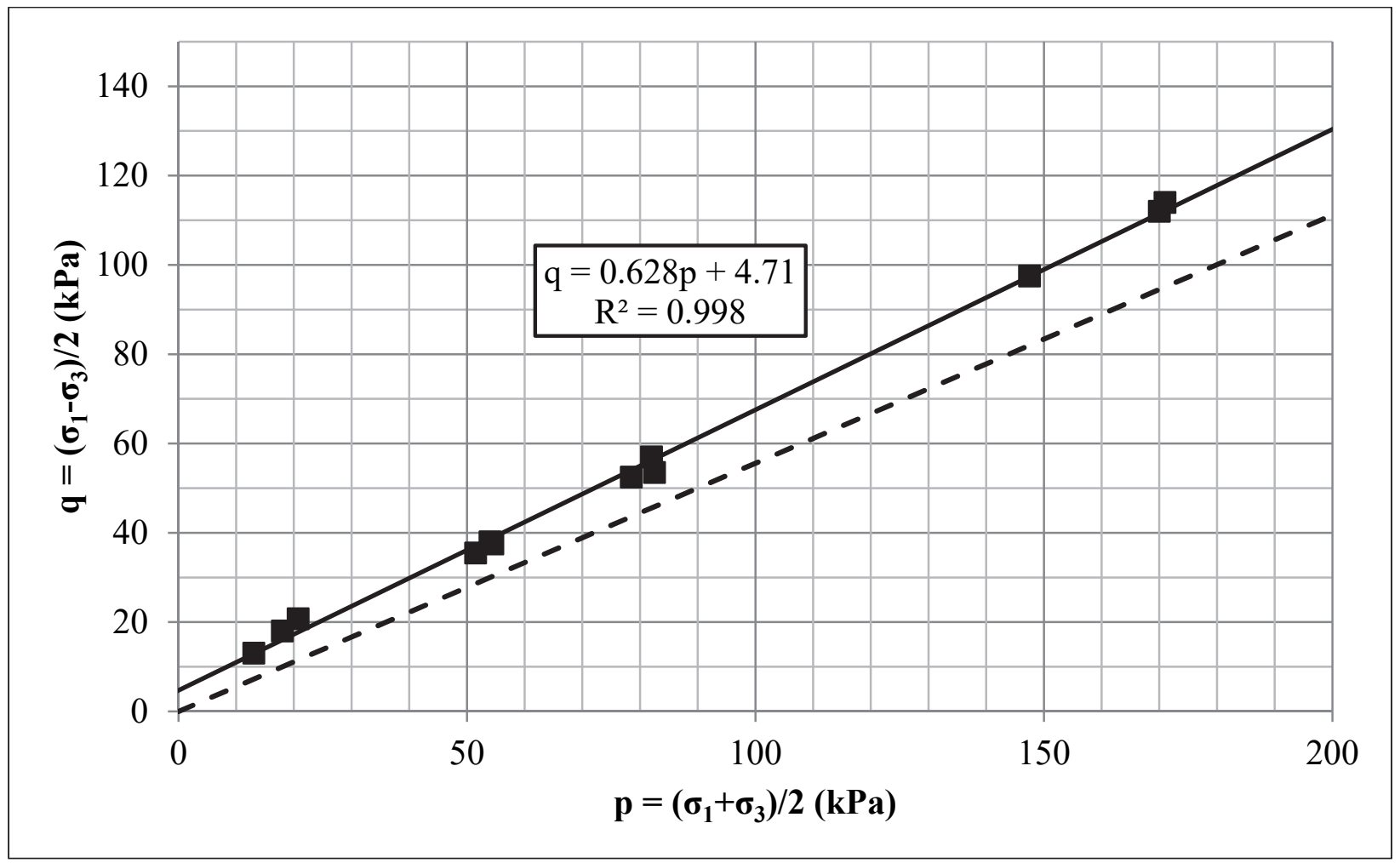

Figure 9. SM triaxial results. Dashed line indicates the theoretical failure plane, and the solid line indicates the observational failure plane.

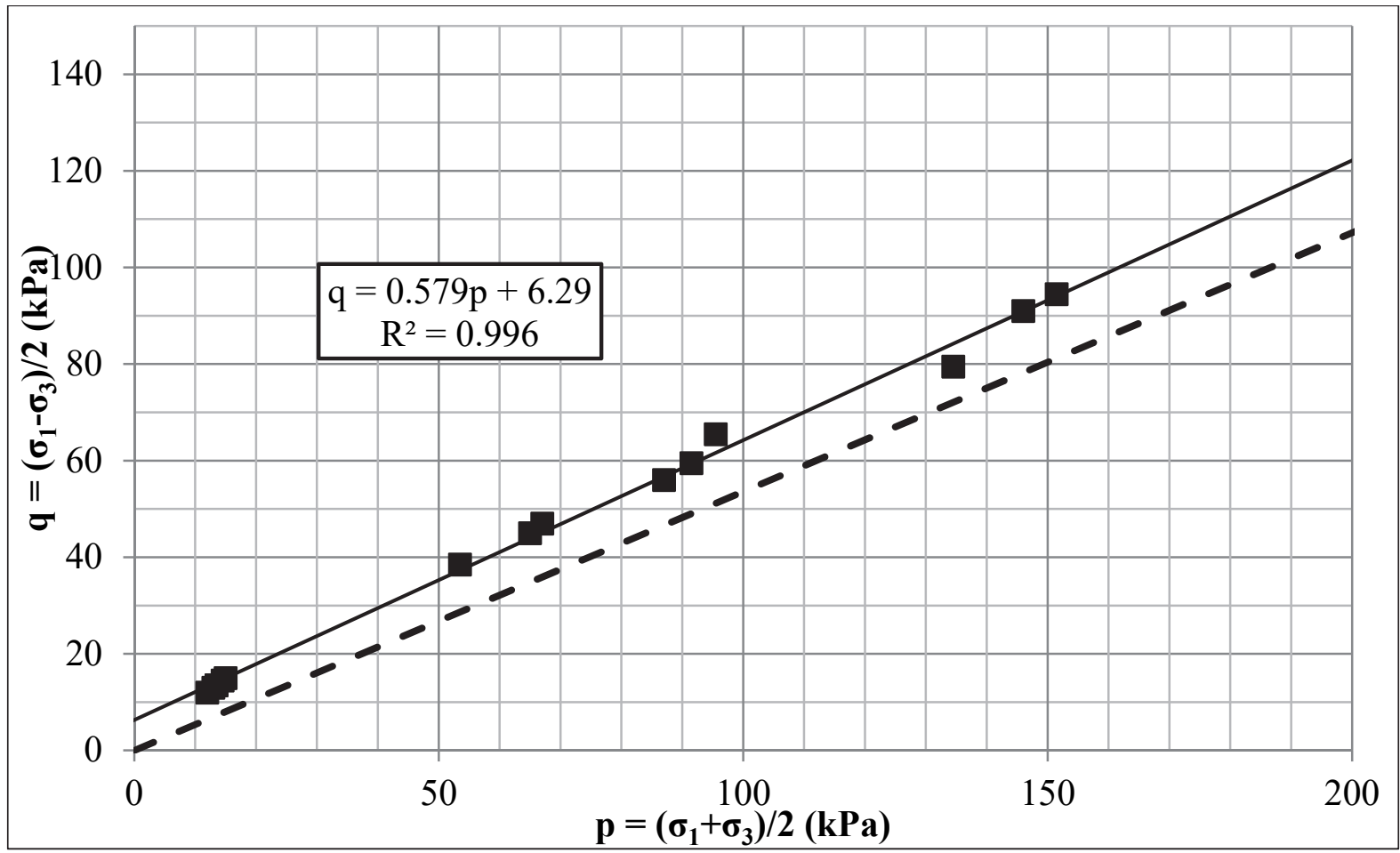


Figure 10. ML triaxial results. Dashed line indicates the theoretical failure plane, and the solid line indicates the observational failure plane.

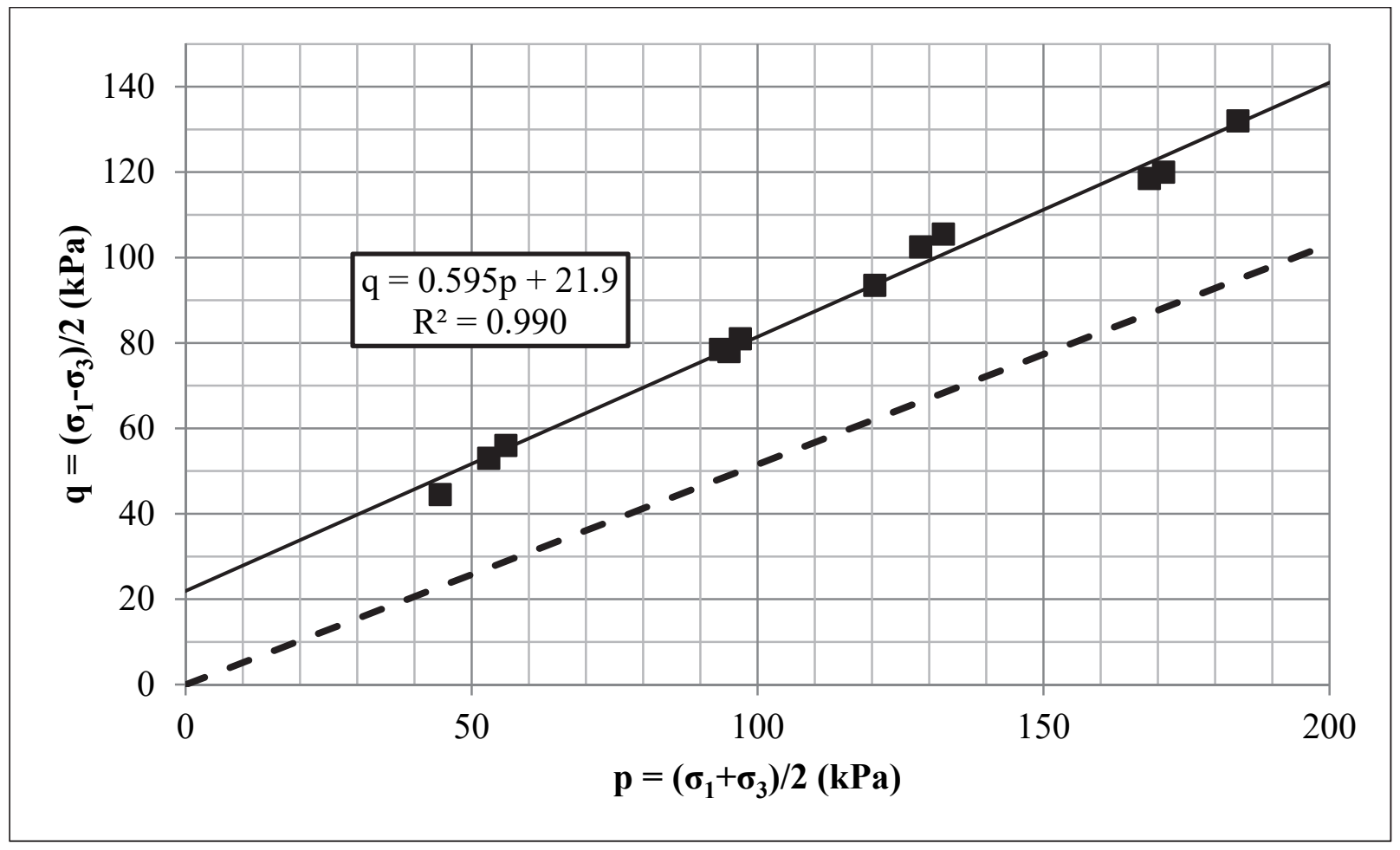

\subsection{Simple shear}

Table 2 lists the confining pressures and average shear stresses at failure from the simple shear tests conducted for this study, for a total of 81 simple shear tests. Simple shear failure strength was determined as the maximum shear stress at or below 3.5 percent shear strain for specimens tested at or below 100-kPa cell pressure, 7.5 percent shear strain for specimens tested at 250-kPa cell pressure, and 10.0 percent shear strain for specimens tested at 500-kPa cell pressure to correspond to observed plateauing of the shear stress relative to the shear strain.

Similar to the observations with the triaxial results, the failure envelope deviated from the theoretical failure plane at low confining pressures. Under near-surface confining pressures, the observational failure planes for the three materials can be best described by a second-order polynomials $\left(\mathrm{R}^{2}=0.981-0.988\right)$ that rejoin the theoretical failure envelope at or near $100 \mathrm{kPa}$. 
Table 2. Simple shear testing summary for near-surface UD and ICD testing.

\begin{tabular}{|l|l|l|l|}
\hline & \multicolumn{3}{|l|}{$\begin{array}{l}\text { Average shear stress } \\
\text { at failure, } \mathrm{kPa}(\mathrm{n}=3)\end{array}$} \\
\hline Confining pressure & $\mathrm{SP}$ & $\mathrm{SM}$ & $\mathrm{ML}$ \\
\hline UD, 2-kPa seating load & 6.6 & 8.8 & 11.9 \\
\hline UD, 5-kPa seating load & 7.4 & 10.8 & 14.5 \\
\hline ICD $15 \mathrm{kPa}$ & 16.1 & 22.5 & 19.0 \\
\hline ICD $25 \mathrm{kPa}$ & 23.4 & 31.3 & 26.0 \\
\hline ICD $50 \mathrm{kPa}$ & 45.4 & 39.3 & 38.4 \\
\hline ICD $75 \mathrm{kPa}$ & 57.3 & 55.2 & 49.1 \\
\hline ICD $100 \mathrm{kPa}$ & 64.7 & 64.4 & 56.4 \\
\hline ICD $250 \mathrm{kPa}$ & 176 & 160 & 142 \\
\hline ICD $500 \mathrm{kPa}$ & 305 & 301 & 266 \\
\hline
\end{tabular}

For SP (Figure 11) and SM (Figure 12), the greatest difference between the theoretical plane and the observational envelope occur at about $50 \mathrm{kPa}$. The effects of the soil continuum fabric decrease with increasing confining pressure until the observational envelope rejoins the Mohr-Coulomb failure line at $100 \mathrm{kPa}$. For ML (Figure 13), the greatest difference between the theoretical plane and the observational envelope is seen when the soil is unconfined. The effects of the soil continuum fabric decrease with increasing confining pressure until the observational envelope joins the Mohr-Coulomb failure envelope between 75 and $100 \mathrm{kPa}$. 
Figure 11. SP low confinement simple shear results.

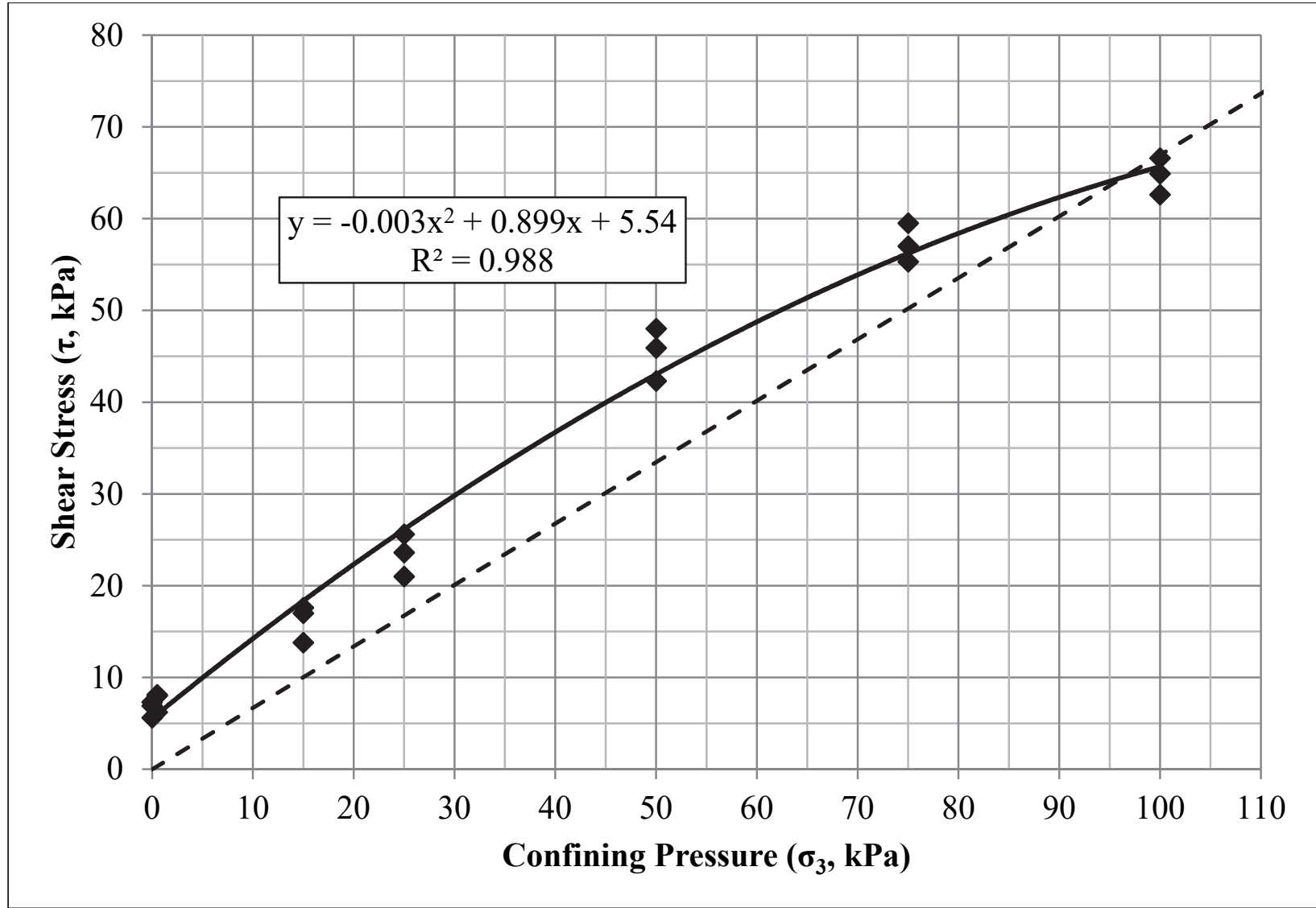

Figure 12. SM low confinement simple shear results.

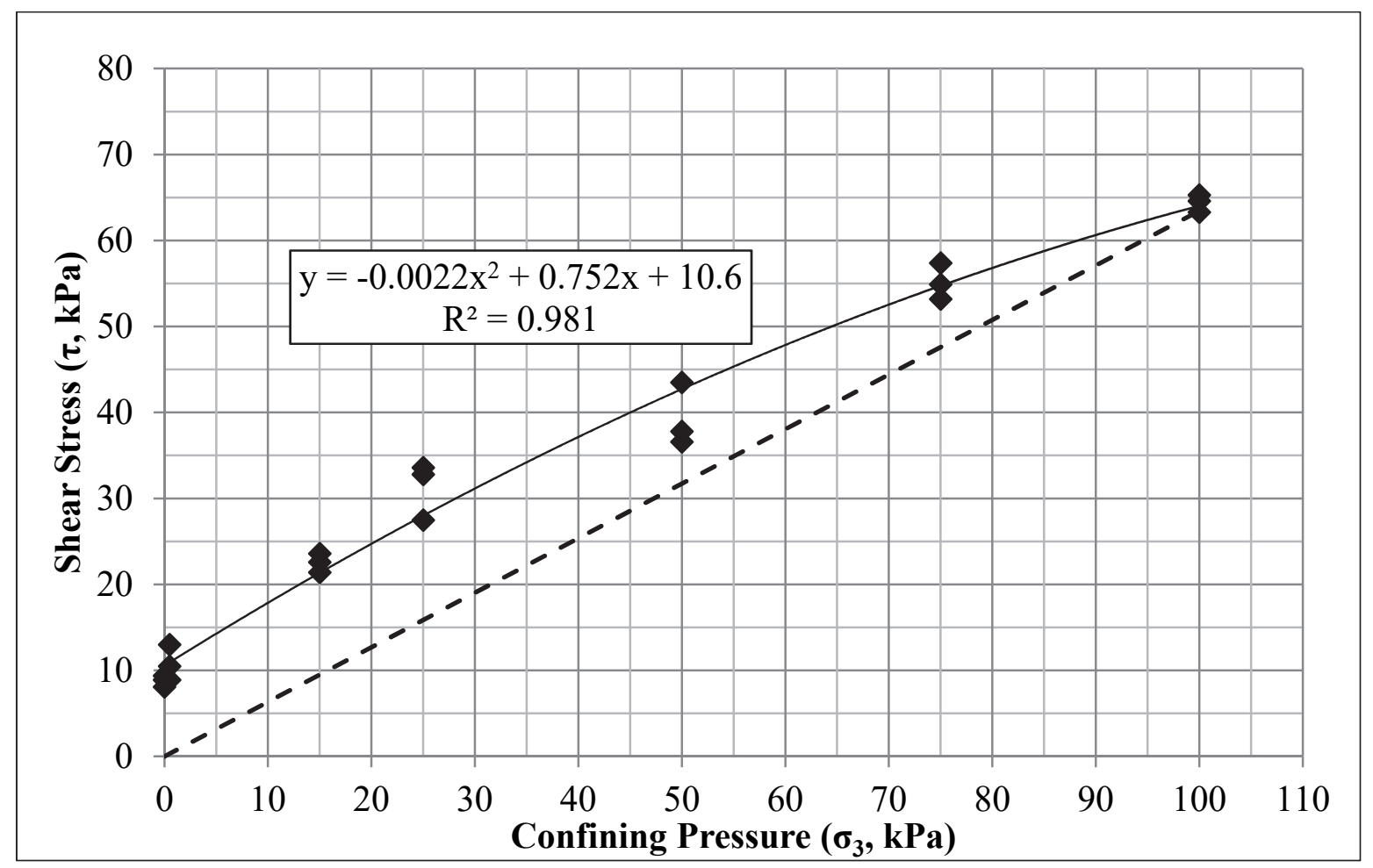


Figure 13. ML low confinement simple shear results.

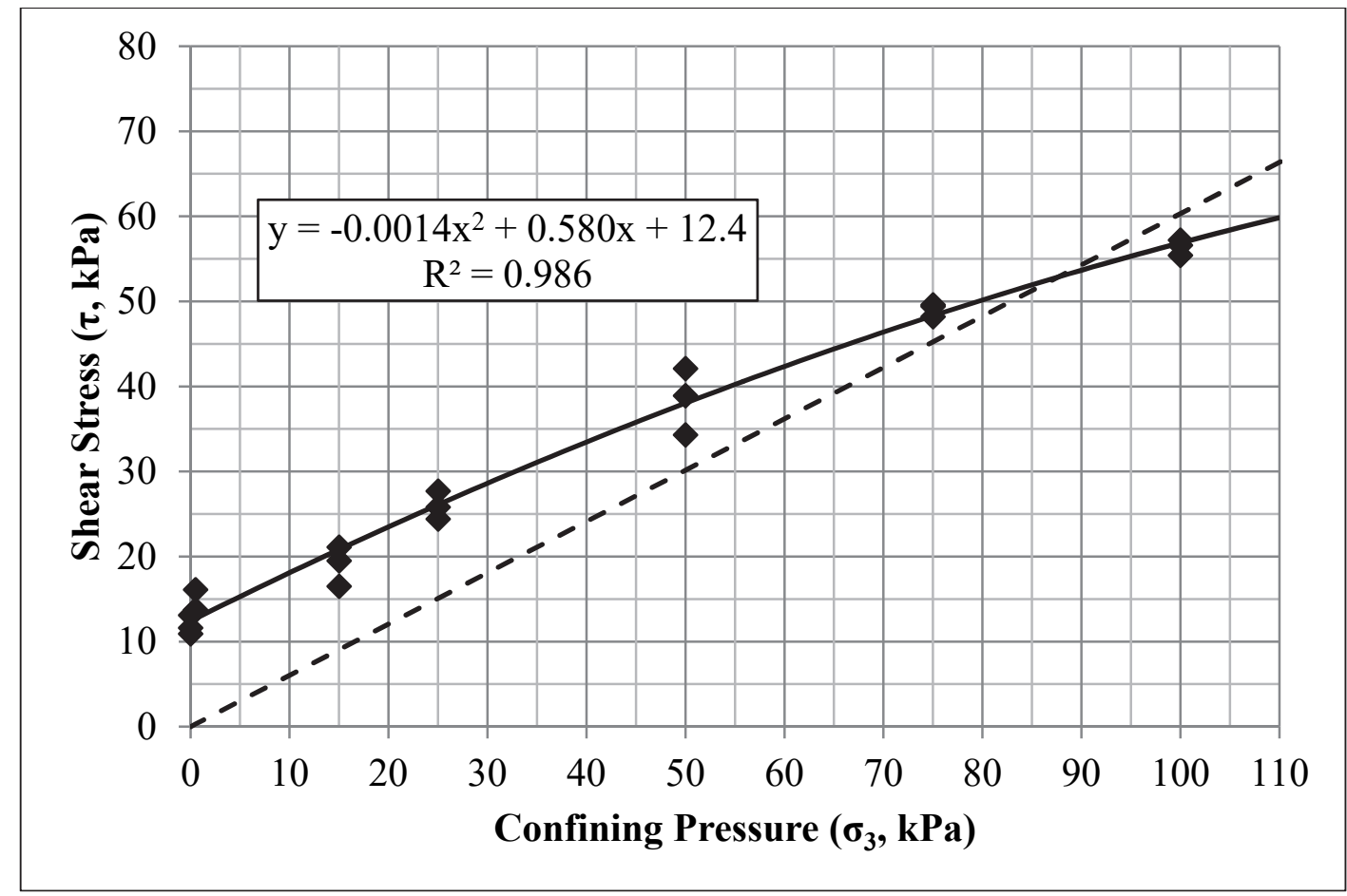

\subsection{Cyclic ring shear}

Table 3 lists the confining pressures, cyclic strain and shear stress at failure, and cyclic strain and shear stress at critical state from the SP cyclic ring shear tests performed for this study, for a total of 50 cyclic ring shear tests. Ten repetitions of each confining pressure were performed, and each test yielded both failure and critical state data. Failure strength was determined as the maximum shear stress and cyclic strain on the fourth cycle of testing. Critical state shear stress and cyclic strain were determined from the tenth cycle of testing.

Table 3. SP cyclic ring shear testing summary.

\begin{tabular}{|l|l|l|l|l|}
\hline \multirow{2}{*}{$\begin{array}{c}\text { Confining } \\
\text { pressure } \\
(\mathrm{kPa})\end{array}$} & \multicolumn{1}{|c|}{$\begin{array}{c}\text { Cyclic } \\
\text { strain (\%) }\end{array}$} & $\begin{array}{c}\text { Shear } \\
\text { stress } \\
(\mathrm{kPa})\end{array}$ & $\begin{array}{c}\text { Cyclic } \\
\text { strain (\%) }\end{array}$ & $\begin{array}{c}\text { Shear } \\
\text { stress } \\
(\mathrm{kPa})\end{array}$ \\
\hline 10 & 0.213 & 16.86 & 0.211 & 20.64 \\
\hline 25 & 0.212 & 31.29 & 0.211 & 38.17 \\
\hline 50 & 0.213 & 50.38 & 0.210 & 60.51 \\
\hline 75 & 0.212 & 69.40 & 0.210 & 81.18 \\
\hline 100 & 0.212 & 86.29 & 0.210 & 99.83 \\
\hline
\end{tabular}


Test data are plotted in Figure 14 and Figure 15. Both graphs show weak relationships between cyclic strain confining pressure. However, there are strong relationships between shear stress and confining pressure $\left(\mathrm{R}^{2}>0.96\right)$. Similar to triaxial and simple shear testing, these trendlines also contain non-zero intercepts.

Figure 14. SP cyclic ring-shear shear stress and cyclic strain at failure.

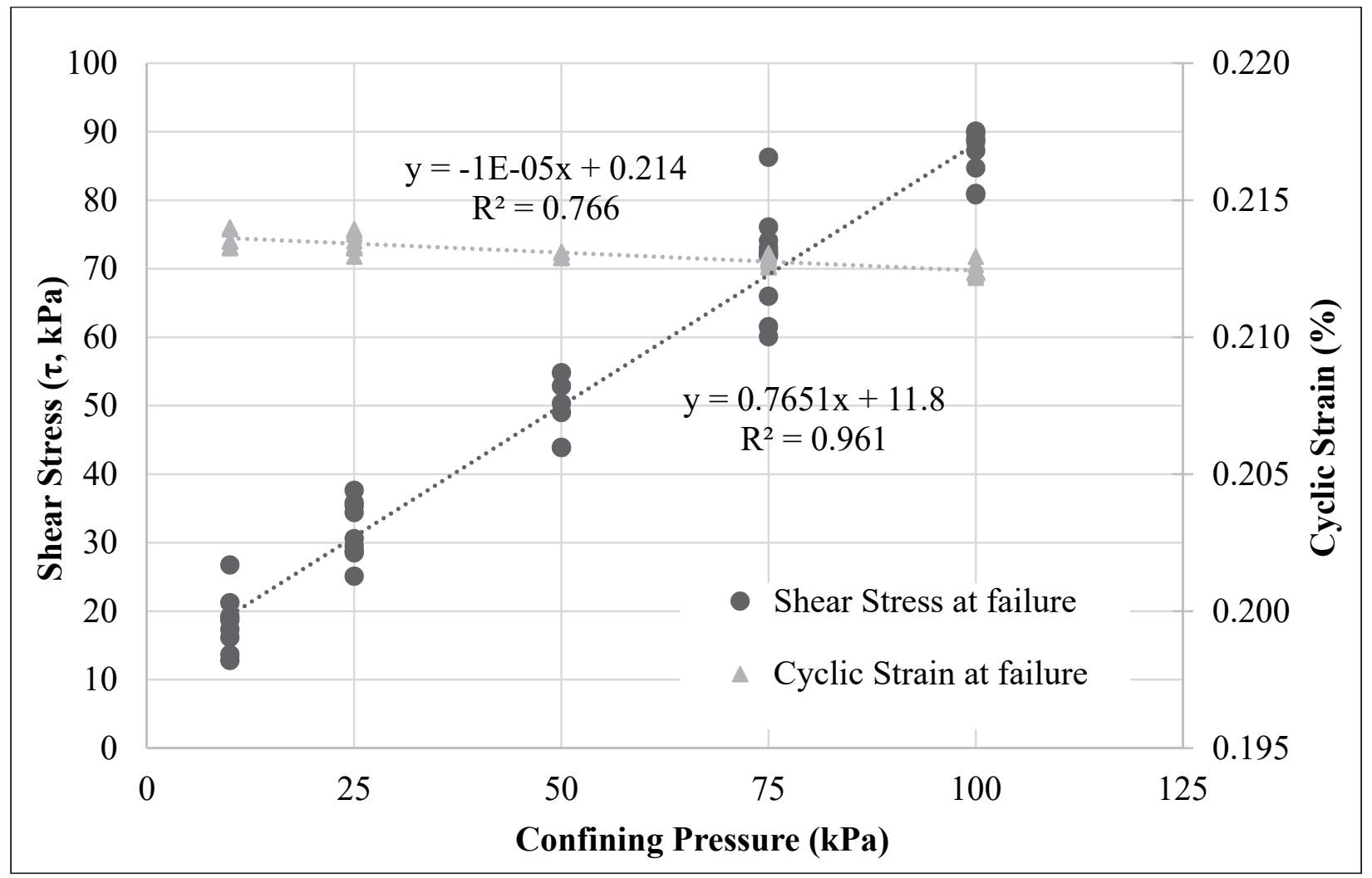


Figure 15. SP cyclic ring-shear shear stress and cyclic strain at critical state.

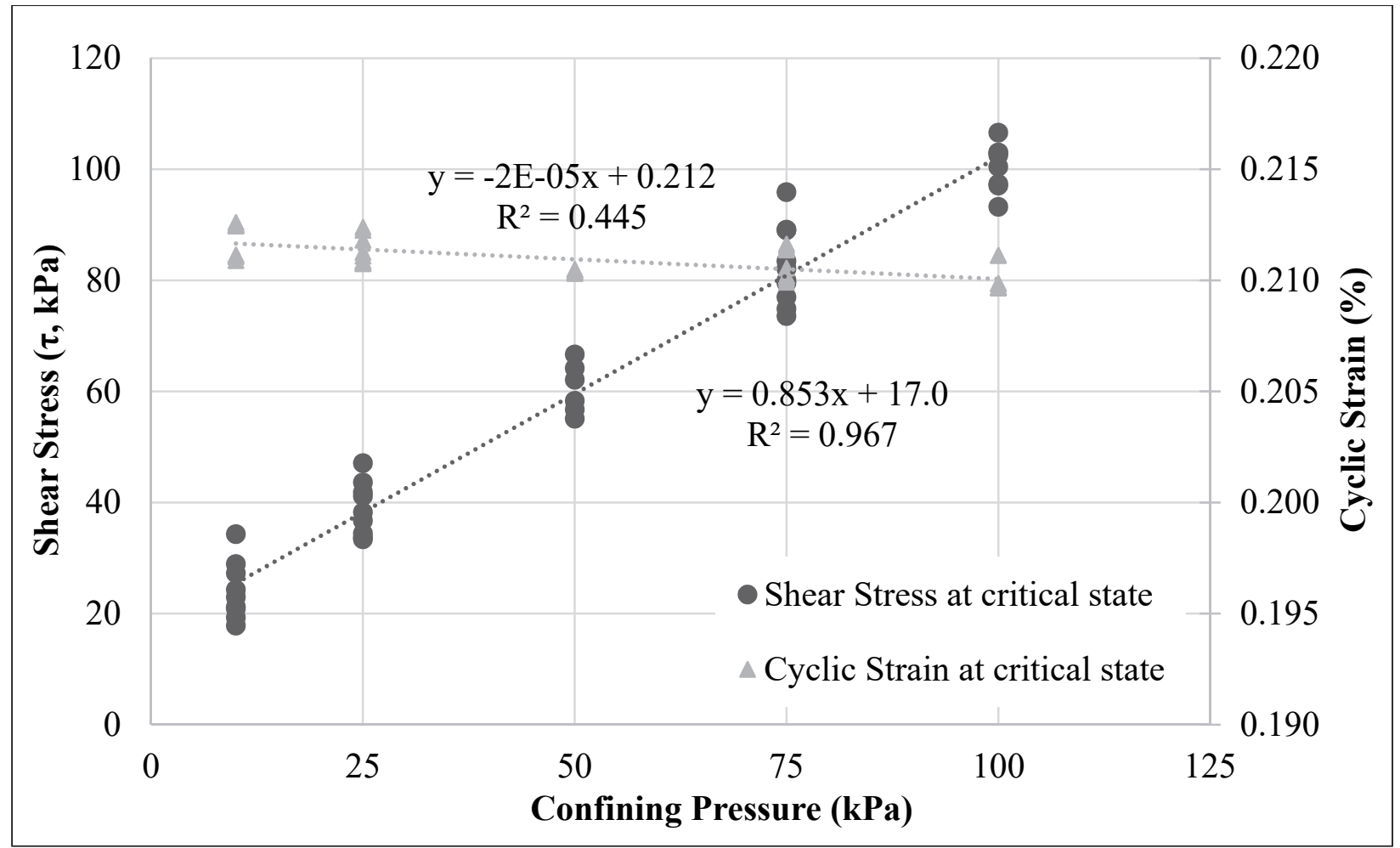




\section{Discussion}

The data indicate that cohesionless soils exhibit some strength due to the internal structure, not captured by the standard internal friction angle definition, as evidenced by the shear stress intercept of the trendlines. The variance in friction angle between the theoretical Mohr-Coulomb and observed data for axial loading conditions is relatively minor, 3 to 5 deg, and therefore would often be ignored in most geotechnical problems. This minor deviation in $\phi$ suggests that other failure mechanics that are influencing the overall strength are not captured in conventional MohrCoulomb failure plane derivation at near-surface conditions. At higher confining pressures, the data trend to the theoretical Mohr-Coulomb failure plane. This implies that the internal frictional component $\phi$ dominates the continuum strength and the inter-granular fabric contribution is negligible. However, under low confinement, the continuum fabric dominates the angle of the Mohr envelope.

Triaxial and simple shear tests are designed to test soil under different conditions and therefore yield different results, but the two can be compared (Budhu 1984). The data show that the soil continuum fabric, akin to cohesion in clays, dominates the shear resistance of the material for confining pressures below $100 \mathrm{kPa}$. At confining pressures above 100 $\mathrm{kPa}$, the observational and theoretical Mohr-Coulomb failure planes are generally identical for simple shear. This implies that the internal friction caused by the confining pressure, not the internal fabric, provides the continuum strength. Additionally, this suggests that the contributing factors in near-surface failure mechanics is not well understood.

Of significant interest is the difference in the shape of the Mohr envelope between axial and shear loading. The linear nature of the axial loading is similar to the frictional roughness of quartz minerals and surface water tension. However, the non-linear behavior in shear loading implies that the fabric behavior, which dominates the soil strength in low-confinement regions, cannot be inferred by linear approximations and is far more complex mechanically.

The ACUCYC,RS data showed similar behavior to failure as both the triaxial and simple shear results, wherein at low confining stresses (less than 100 $\mathrm{kPa}$ ), there is an increase over expected Mohr-Coulomb mechanics. Post failure, the SP material exhibited a small strain hardening increase in 
shear stress to the critical state. While the magnitude of this increase is relatively minor, it represents a significant statistical increase (nearly $5^{0}$ percent increase at no confinement) that is otherwise unaccounted for in the typical assumption of Mohr-Coulomb governance. As with the triaxial and simple shear results, the ACUCYC,RS critical state data imply that the governing mechanics in the near-surface environment are not simply controlled by the confining pressures and are more complex than approximated by Mohr-Coulomb mechanics.

In all loading cases, there is a $y$-intercept ( $c^{\prime}$ ) suggesting that even a nonplastic cohesionless material will retain some degree of internal structure even without confining pressures. The magnitude of the $y$-intercept is relatively independent of the method of loading. This implies that the initial fabric strength is an intrinsic soil property, i.e., a function of the size of the grains and the ability of the granular friction to resist gravitational forces at the particle level, but is behaviorally variable as a function of both confining pressure and loading mechanism.

\subsection{Sensor implications}

While traditional geotechnical engineering often neglects near-surface soil behavior, it becomes critical in certain applications, including soil-sensor performances. These findings are particularly important as they relate to soil modulus values. The dynamic shear modulus is the principal soil property for evaluating wave propagation and dynamic response of soils. Although studies of dynamic soil properties within the laboratory environment, such as resonant column testing, have been performed for several decades, the effects of saturation, particle size and shape, gradation, and matrix suction were not investigated until the early $1980 \mathrm{os}$ (Wu et al. 1984; Qian et al. 1991; Wheeler et al. 2003; Biglari et al. 2012). Further, very little research has been performed on anisotropic shear moduli for unsaturated soils ( $\mathrm{Ng}$ and Yung 2008; $\mathrm{Ng}$ et al. 2009). The near-surface stress-state is not considered in these recent studies where the effects of the internal soil continuum fabric-structure have a more significant role in soil behavior and soil-structure interactions, e.g., the effects of near-surface conditions on geophysical system performance.

The magnitude of hysteretic damping, or signal loss, is controlled through volumetric and distortional elastic deformations, which are governed by the bulk $(K)$ and shear $(G)$ moduli (Wood 1990). In the case of non-linear elastic materials such as soil, as the fabric yields, degradation of $G$ occurs, 
and energy is lost through hysteretic damping. Over the past four decades, extensive research into determining accurate magnitudes of $G$ has shown that the shear modulus is dependent on four main factors: (1) mean confining pressure ( $\sigma^{\prime} m$ ); (2) strain amplitude; (3) void ratio; and (4) in dry and water-saturated sands, $G$ is not influenced by the oscillating frequencies up to $100 \mathrm{~Hz}$ (Hardin and Richart 1963; Seed and Idriss 1970; Richart et al. 1970; Hardin and Drnevich 1972; Iwasaki et al. 1974; Tatsuoka et al. 1978; Seed et al. 1986; Bolton and Wilson 1990). None of these studies investigated the low confining environments of the near surface yet are used to infer behavior.

For monotonic axial strength, none of the materials rejoin the MohrCoulomb failure line until the confining pressures exceed the depths of sensor placement. This would signify an increase in bulk modulus, $K$. However, in shear, the material rejoins the Mohr-Coulomb failure line much sooner. This illustrates a non-linearity between the shear modulus, $G$, and the bulk modulus, $K$, relationship within the near-surface environment. This $G-K$ relationship has first-order impact on signal processing and sensor performance and can explain, in part, the phenomena observed in Taylor et al. (2014). These impacts are not limited to sensor performance, as internal erosion, dam and levee sloughing, and environmental contamination cap designs are all influenced by nearsurface soil behavior.

\subsection{Summary}

The near-surface, low-confinement environment has been largely ignored by geotechnical engineers. Classic theories, such as Mohr-Coulomb failure mechanics and the presumption that cohesionless materials have no unconfined strength, do not hold true when subjected to detailed study. Namely, triaxial and simple shear testing of three materials (SP, SM, and $\mathrm{ML}$ ) at confining pressures under $100 \mathrm{kPa}$ showed significant increases in strength over the expected strengths from Mohr-Coulomb failure mechanics.

Lambe and Whitman (1969) acknowledge that the difference between the observational failure envelope and the theoretical failure plane can be small (less than $5 \mathrm{deg}$ ) and therefore insignificant for many applications. However, these studies were conducted predominately with triaxial and direct shear devices. The direct shear apparatus forces a horizontal failure plane while the simple shear apparatus allows the soil to fail along a true 
failure plane. Therefore, to study shear loading at low confinement, simple shear testing was performed.

In respect to triaxial testing, the variance from the theoretical is relatively minor and follows a failure envelope in accordance with the mineralogical granular friction angle. However, in simple shear testing, it is evident that the internal fabric behavior dominates the shear resistance in lowconfining-stress environments. Moreover, the shape of the simple shear failure envelope is non-linear and significantly stronger than the theoretical limit of Mohr-Coulomb mechanics for a cohesionless material. In both the triaxial and simple shear cases, the internal unconfined fabric strengths are in relatively close agreement for each material. This suggests that, in nearsurface or low-confinement regions, cohesionless materials behave similarly to overly-consolidated clays, just at a reduced cohesion value. While the SM material did contain 1.7 percent clay, the clay fraction is insufficient to influence the activity of the soil. Additionally, this clay fraction does not yield a plastic limit as defined in ASTM Standard D4318 (ASTM International 2010). The significant difference in the Mohr envelope shape illustrates that the internal fabric's ability to resist different loading mechanisms cannot be assumed by a linear approximation. However, the boundaries and physics of these observations, as well as further study into changes in soil moduli, are the subject of ongoing research. 


\section{References}

Aki, K., and P.G. Richards. 1980. Quantitative seismology: Theory and methods, vols. I and II. San Francisco: W.H. Freeman.

ASTM International. 2010. Standard test methods for liquid limit, plastic limit, and plasticity index of soils. Designation: D4318. West Conshohocken, PA: ASTM International.

Berry, W.W., O.-D.S. Taylor, K.E. Winters, A.L. Cunningham, W.R. Rowland, and M.D. Antwine. 2018. Near surface laboratory testing protocol development. ERDC/GSL TR-18-12. Vicksburg, MS: U.S. Army Engineer Research and Development Center.

Biglari, M., A. d'Onofrio, C. Mancuso, M.K. Jafari, A. Shafiee, and I. Ashayeri. 2012. Small-strain stiffness of Zenoz kaolin in unsaturated conditions. Canadian Geotechnical Journal 49: 311-322.

Bolton, M.D., and J.M.R. Wilson. 1990. Soil stiffness and damping. In Structural dynamics, ed. Kratzig et al., 209-216. Balkema, Rotterdam.

Bonner, J., R. Waxler, Y. Gitterman, and R. Hofstetter. 2013. Seismo-acoustic energy partitioning at near-source and local distances from the 2011 sayarim explosions in the Negev Desert, Israel. Bulletin of the Seismological Society of America April 2013. 103 (2A): 741-758.

Bradshaw, A., and C. Baxter. 2007. Sample preparation of silts for liquefaction testing. Geotech. Testing Journal 3o(4): 324.

Budhu, M. 1984. On comparing simple shear and triaxial test results. J. of Geotech. Engineering 11O(12): 1809-1814.

Chapman, M. April 2013. On the rupture process of the 23 August 2011 Virginia Earthquake. Bulletin of the Seismological Society of America 103(2A): 613-628.

Das, B.M. 2002. Principles of Geotechnical Engineering. Pacific Grove, CA: Brooks/Cole.

Fannin, R.J., A. Eliadorani, and J.M.T. Wilkinson. 2005. Shear strength of cohesionless soils at low stress. Geotechnique 55(6): 467-478.

Graham, S.S., S.A. Akers, K.J. Ratliff, and T.A. Waddell. 2014. Laboratory characterization of Aberdeen test center engineered roadway soil. ERDC/GSL TR-14-36. Vicksburg, MS: U.S. Army Engineer Research and Development Center.

Hardin, B.O., and V.P. Drnevich. 1972. Shear modulus and damping in soils: Design equations and curves. Journal of the Soil Mechanics and Foundation Division (ASCE) 98 (SM7): 667-692.

Hardin, B.O., and F.E. Richart. 1963. Elastic wave velocities in granular soils. Journal of the Soil Mechanics and Foundation Division (ASCE) 89: 33-65. 
Huang, Y., H. Cheng, T. Osada, A. Hosoya, and F. Zhang. 2015. Mechanical behavior of clean sand at low confining pressure: Verification with element and model tests. J. of Geotech. and Geoenvironmental Engineering 06015005-1-06015005-6.

Iwasaki, T., F. Tatsuoka, and Y. Takagi. 1974. Shear moduli of sands under cyclic torsional shear loading. Soils and Foundations (JSSMFE) 18(1:39-56).

Koper, K.D., T.C. Wallace, and R.C. Aster. 2003. Seismic recordings of the Carlsbad, New Mexico, pipeline explosion of 19 August 2000. Bulletin of the Seismological Society of America 93(4): 1427-1432.

Koustuvee, K., A. Sridharan, and M. Chetia. 2014. Investigation into the influence of grain shape and size on shear strength of cohesionless soils. Proc. GeoCongress 2014, GSP 234, ASCE, Atlanta, GA: 84-92.

Lambe, T.W., and R.V. Whitman. 1969. Soil mechanics. New York: John Wiley \& Sons.

Lancelot, L., I. Shahrour, and M. Al Mahmoud. 2006. Failure and dilatancy properties of sand at relatively low stresses. J. of Engineering Mechanics 132(12): 1396-1399.

Mitchell, J.K., and K. Soga. 2005. Fundamentals of soil behavior. Hoboken, NJ: John Wiley \& Sons.

Mykkeltveit, S., F. Ringdal, T. Kvoerna, and R.W. Alewine. 1990. Application of regional arrays in seismic verification. Bulletin of Seismological Society of America 8ob: 1777-180o.

Ng, C.W.W., and S.Y. Yung. 2008. Determination of the anisotropic shear stiffness of an unsaturated decomposed soil. Geotechnique 58(1): 23-35.

Ng, C.W.W., J. Xu, and S.Y. Yung. 2009. Effects of wetting-drying and stress ratio on anisotropic stiffness of an unsaturated soil at very small strains. Canadian Geotechnical Journal 46: 1062-1076.

Qian, X., D.H. Gray, and R.D. Woods. 1991. Resonant Column Tests on Partially Saturated Sands. Geotechnical Testing Journal GTJODJ 14(3): 266-275.

Richart, F.E., J.R. Hall, and R.D. Woods. 1970. Vibrations of soil and foundations. Englewood Cliffs, NJ: Prentice-Hall Inc.

Ringdal, F., and E.S. Husebye. 1982. Application of arrays in the detection, location, and identification of seismic events. Bulletin of the Seismological Society of America 72(6): S2O1-S224.

Seed, H.B., and I.M. Idriss. 1970. Soil moduli and damping factors for dynamic response analysis. Report No. EERC 70-10. Berkeley, CA: Earthquake Engineering Research Center, University of California.

Seed, H.B., R.T. Wong, I.M. Idriss, and K. Tokimatsu. 1986. Moduli and damping factors for dynamic analyses of cohesionless soils. Journal of Geotechnical Engineering (ASCE) 112(11): 1016-1032.

Sheriff, R.E., and L.P. Geldhart. 1995. Exploration seismology, second edition. New York: Cambridge University Press. 
Stump, B.W., D.C. Pearson, and R.E. Reinke. 1999. Source comparisons between nuclear and chemical explosions detonated at Rainier Mesa, Nevada Test Site. Bulletin of the Seismological Society of America 89(2)409-422.

Tatsuoka, F., T. Iwasaki, and Y. Takagi. 1978. Hysteretic damping of sands under cyclic loading and its relation to shear modulus. Soils and Foundations (JSSMFE) 18(2): 25-40.

Taylor, O.-D. S. 2011. Use of an energy-based liquefaction approach to predicting deformation in silts due to pile driving. PhD diss., University of Rhode Island, $303 \mathrm{p}$.

Taylor, O.-D.S., C.D. Baxter, A.S. Bradshaw, and A.C. Morales. 2012. New density normalization approach for evaluation of the cyclic resistance of silts. GeoCongress 2012 (809-818).

Taylor, O.-D.S., M.H. McKenna, J.R. Kelley, B.G. Quinn, and J. McKenna. 2014. Partially saturated soil causing significant variability in near surface seismic signals. Near Surface Geophysics 12(4): 467-480.

Taylor, O.-D.S, W.W. Berry, K.E. Winters, W.R. Rowland, M.D. Antwine, and A.L. Cunningham. 2016. Protocol for cohesionless sample preparation for physical experimentation. ERDC/GSL Technical Report TR-16-11. Vicksburg, MS: U.S. Army Engineer Research and Development Center.

Tsoflias, G.P., D.W. Steeples, G.P. Czarnecki, S.D. Sloan, and R.C. Eslick. 2006. Automatic deployment of a 2-D geophone array for efficient ultra-shallow seismic imaging. Geophys. Res. Lett. 33: Lo9301.

Wheeler, S.J., R.S. Sharma, and M.S.R. Buisson. 2003. Coupling of hydraulic hysteresis and stress-strain behavior in unsaturated soils. Geotechnique 53(1): 41-54.

Winters, K.E., O.-D.S. Taylor, W.W. Berry, W.R. Rowland, M.D. Antwine, and A.L. Cunningham. 2016. Cohesionless soil fabric and shear strength at low confining pressures. ASCE GeoChicago.

Wood, D.M. 1990. Soil behaviour and critical state soil mechanics. New York: Cambridge University Press.

Wu, S., D.H. Gray, and F.E. Richart. 1984. Capillary effects on dynamic modulus of sands and silts. Journal of the Geotechnical Engineering Division (ASCE) 110 (GT9): 1188-1203. 


\section{Appendix A: Test Data}

\section{Triaxial test data}

\section{SP triaxial test data}

\begin{tabular}{|c|c|c|c|}
\hline $\begin{array}{c}\text { Target Cell } \\
\text { Pressure }(\mathrm{kPa})\end{array}$ & $\begin{array}{c}\text { Cell Pressure } \\
\text { at } \sigma_{\mathrm{d}} \text { Max }(\mathrm{kPa})\end{array}$ & $\begin{array}{c}\text { Maximum Deviator } \\
\text { Stress }\left(\sigma_{d}, \mathrm{kPa}\right)\end{array}$ & Test Name \\
\hline 1000 & 1000 & 2311 & $20150722 \mathrm{~A}$ \\
\hline 1000 & 1001 & 2303 & $20150722 \mathrm{C}$ \\
\hline 1000 & 1001 & 2299 & $20150916 \mathrm{~B}$ \\
\hline 500 & 506 & 1531 & $20150724 \mathrm{~A}$ \\
\hline 500 & 507 & 1598 & $20150724 \mathrm{~B}$ \\
\hline 500 & 502 & 1552 & $20150916 \mathrm{~A}$ \\
\hline 100 & 108 & 408 & $20150617 \mathrm{~A}$ \\
\hline 100 & 110 & 405 & $20150630 \mathrm{~A}$ \\
\hline 100 & 100 & 397 & $20150706 \mathrm{~A}$ \\
\hline 50 & 58 & 224 & $20150729 \mathrm{~A}$ \\
\hline 50 & 57 & 228 & $20150730 \mathrm{~A}$ \\
\hline 50 & 50 & 195 & $20150921 \mathrm{~A}$ \\
\hline 25 & 26 & 105 & $20150921 \mathrm{~B}$ \\
\hline 25 & 25 & 114 & $20150922 \mathrm{~A}$ \\
\hline 25 & 29 & 107 & $20150922 \mathrm{~B}$ \\
\hline 15 & 16 & 71 & $20150923 \mathrm{~A}$ \\
\hline 15 & 16 & 76 & $20150928 \mathrm{~A}$ \\
\hline 15 & 17 & 75 & $20150928 \mathrm{~B}$ \\
\hline 0 & 0 & 26 & $20150929 \mathrm{~A}$ \\
\hline 0 & 0 & 36 & $20150929 \mathrm{~B}$ \\
\hline 0 & 0 & 42 & $20150929 \mathrm{C}$ \\
\hline
\end{tabular}



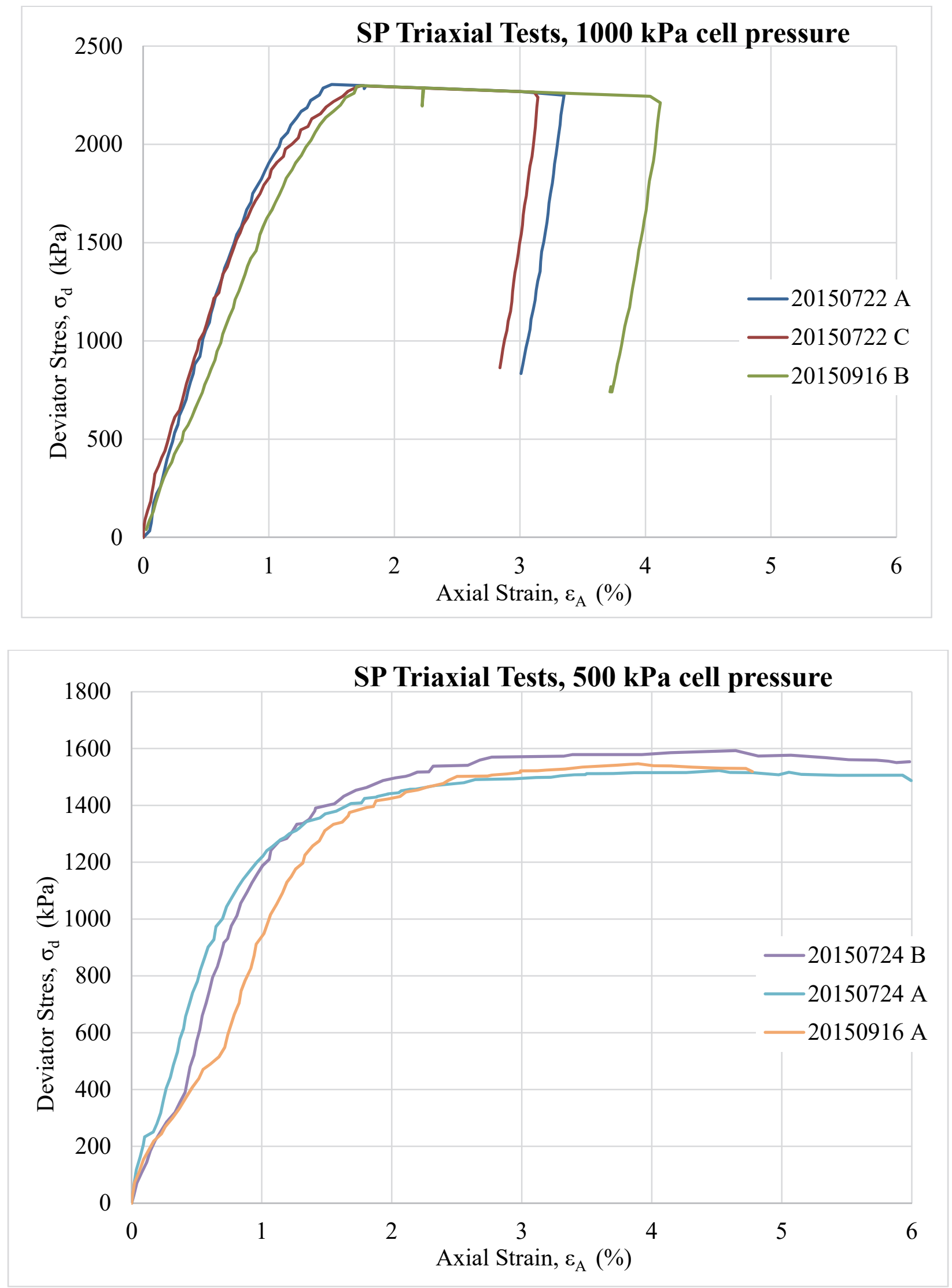

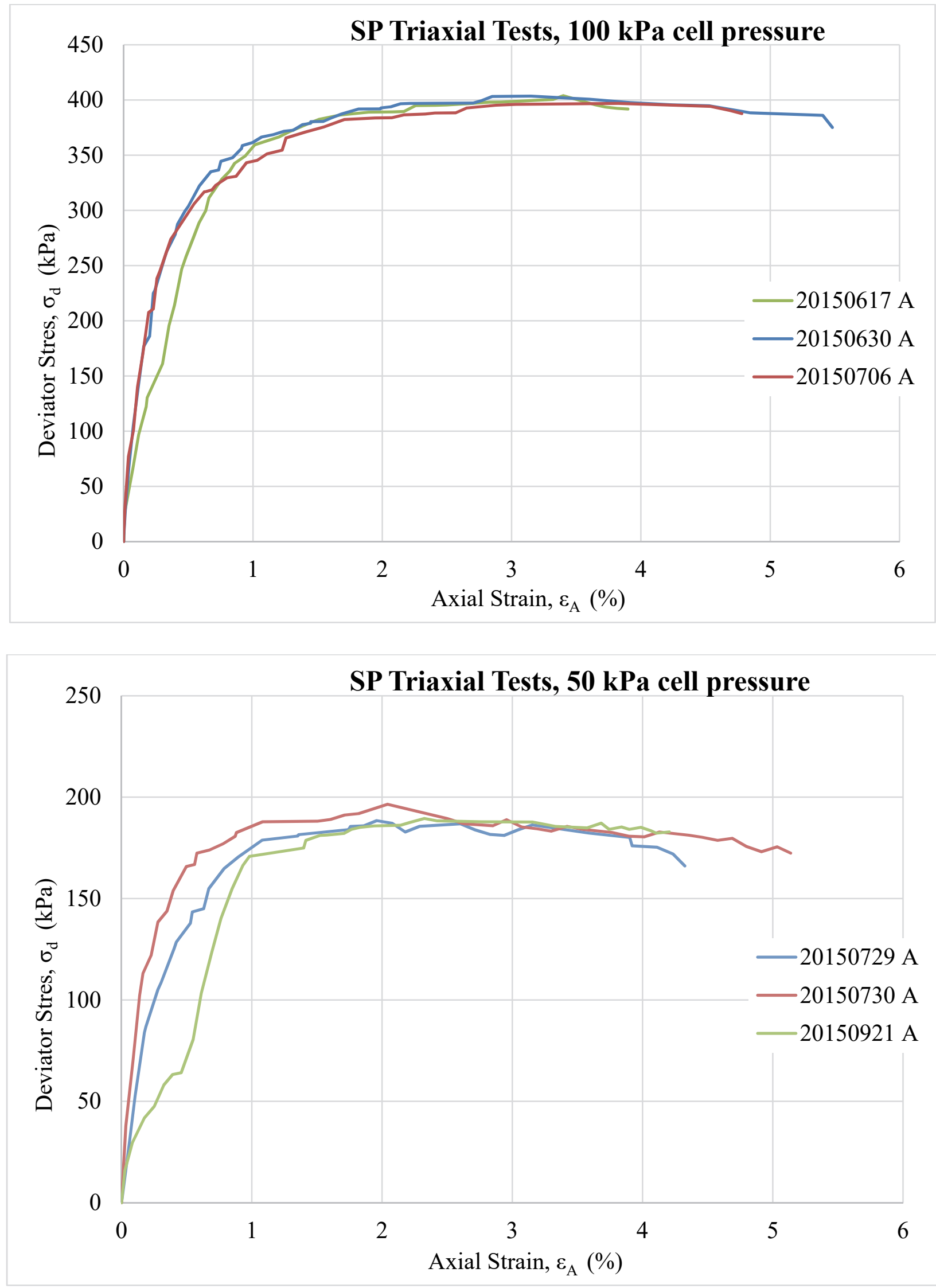

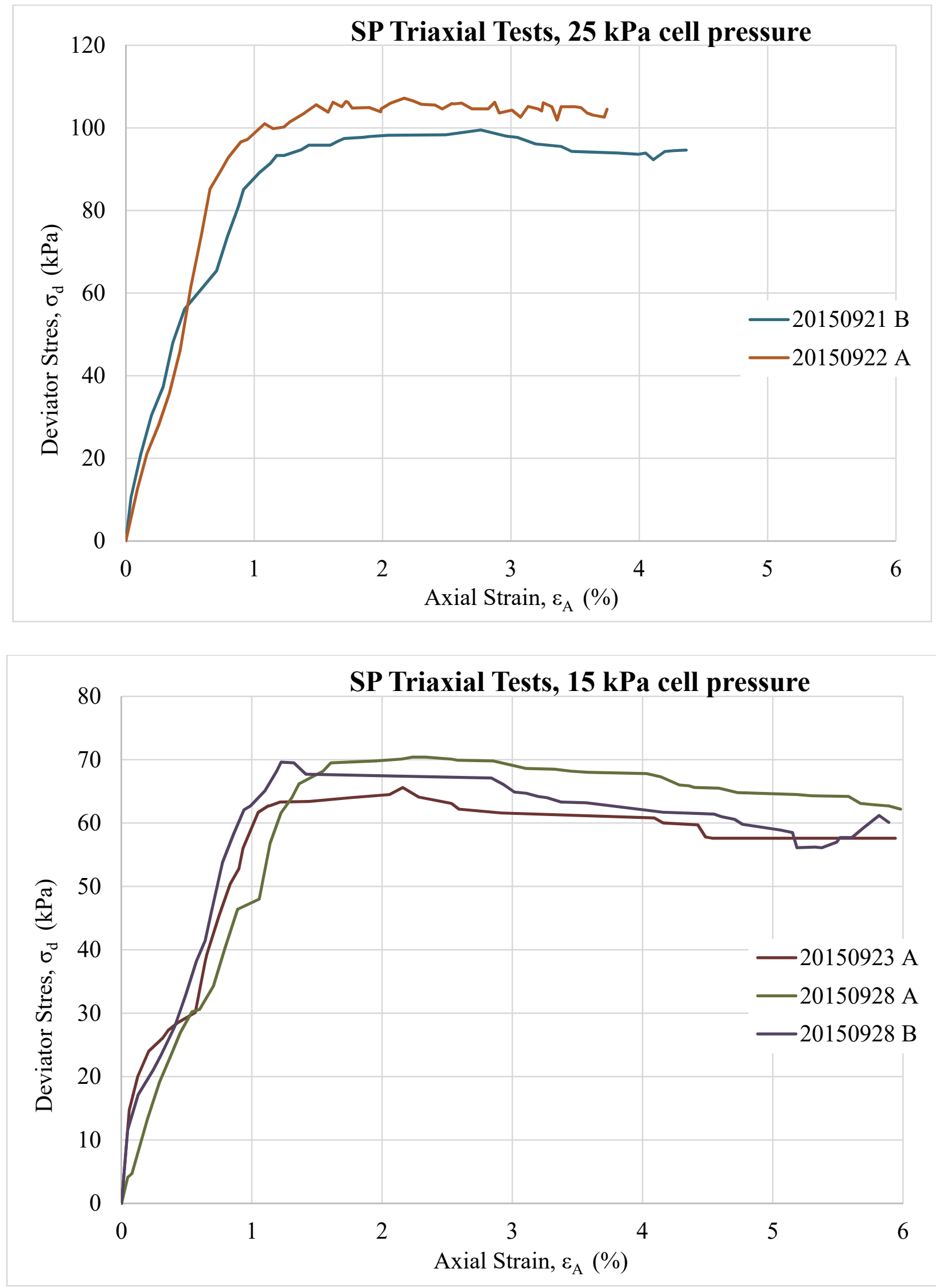


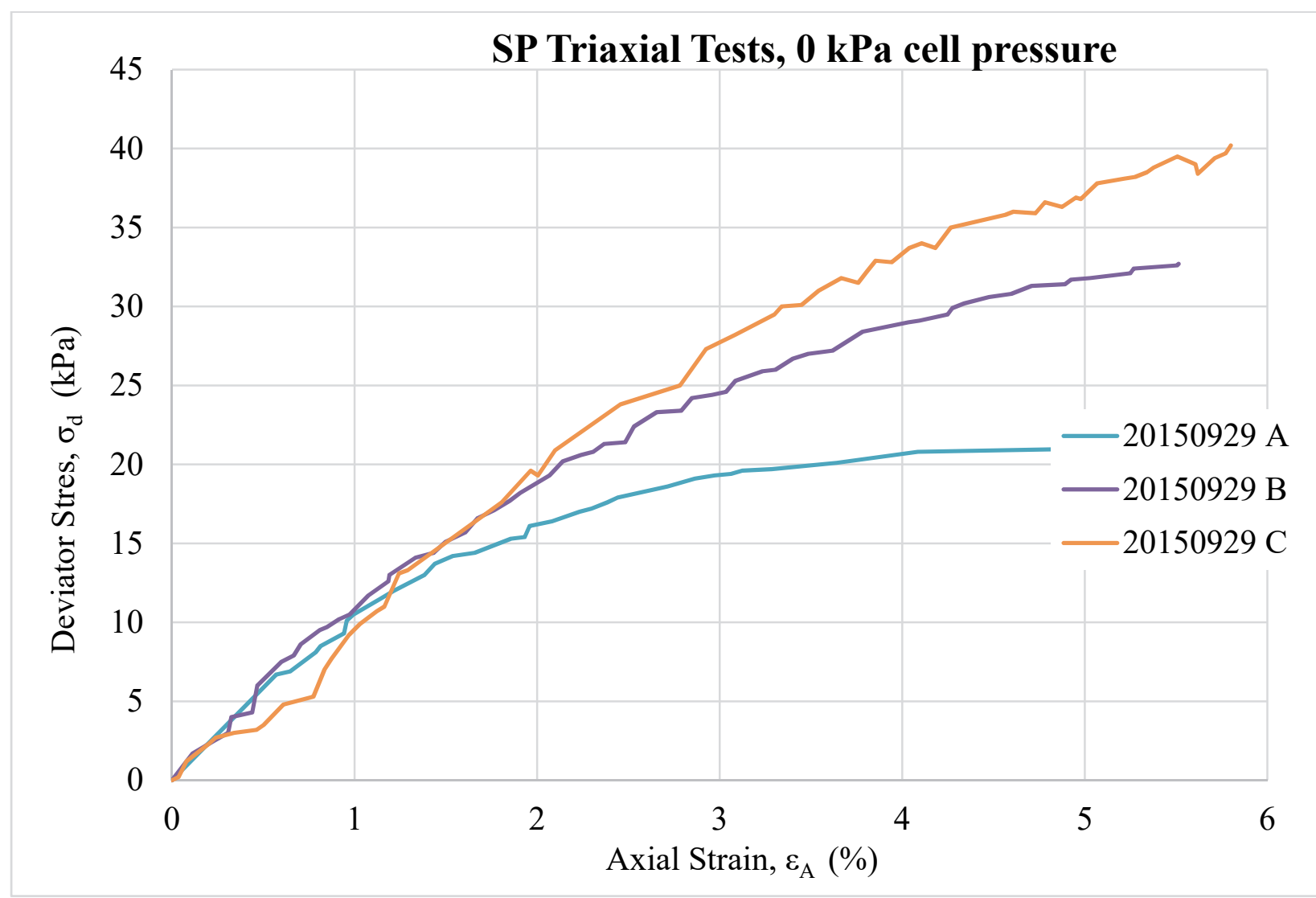


SM triaxial test data

\begin{tabular}{|c|c|c|c|c|}
\hline $\begin{array}{l}\text { Target } \\
\text { Cell Pressure } \\
(\mathrm{kPa})\end{array}$ & $\begin{array}{c}\text { Cell Pressure } \\
\text { at } \sigma_{d} \operatorname{Max}(\mathrm{kPa})\end{array}$ & $\begin{array}{c}\text { Maximum } \\
\text { Deviator Stress } \\
\left(\sigma_{\mathrm{d}}, \mathrm{kPa}\right)\end{array}$ & Test Name & Membrane \\
\hline 1000 & 999 & 2167 & $20160728 \mathrm{~A}$ & Yes \\
\hline 1000 & 999 & 2172 & $20160729 \mathrm{~A}$ & Yes \\
\hline 1000 & 999 & 2172 & $20160802 \mathrm{~A}$ & Yes \\
\hline 500 & 500 & 1381 & $20160229 \mathrm{~A}$ & Yes \\
\hline 500 & 500 & 1350 & 20160229 B & Yes \\
\hline 500 & 500 & 1381 & $20160302 \mathrm{~A}$ & Yes \\
\hline 100 & 106 & 328 & $20150501 \mathrm{~A}$ & Yes \\
\hline 100 & 107 & 330 & $20150504 \mathrm{~A}$ & Yes \\
\hline 100 & 107 & 324 & $20150511 \mathrm{~A}$ & Yes \\
\hline 50 & 55 & 159 & $20150505 \mathrm{~A}$ & Yes \\
\hline 50 & 55 & 182 & $20150505 B$ & Yes \\
\hline 50 & 57 & 189 & $20150506 \mathrm{~A}$ & Yes \\
\hline 25 & 32 & 119 & $20150507 \mathrm{~A}$ & Yes \\
\hline 25 & 31 & 112 & $20150508 \mathrm{~A}$ & Yes \\
\hline 25 & 30 & 131 & $20150513 \mathrm{~A}$ & Yes \\
\hline 15 & 15 & 77 & 20150625 B & Yes \\
\hline 15 & 20 & 94 & $20150626 \mathrm{~A}$ & Yes \\
\hline 15 & 20 & 90 & $20150629 \mathrm{~B}$ & Yes \\
\hline 0 & 0 & 27 & $20150507 \mathrm{~B}$ & Yes \\
\hline 0 & 0 & 27 & $20150507 \mathrm{C}$ & Yes \\
\hline 0 & 0 & 29 & 20150507 D & Yes \\
\hline 0 & 0 & 24 & 20150508 B & No \\
\hline 0 & 0 & 30 & $20150514 \mathrm{~A}$ & No \\
\hline 0 & 0 & 26 & $20150514 \mathrm{~B}$ & No \\
\hline
\end{tabular}



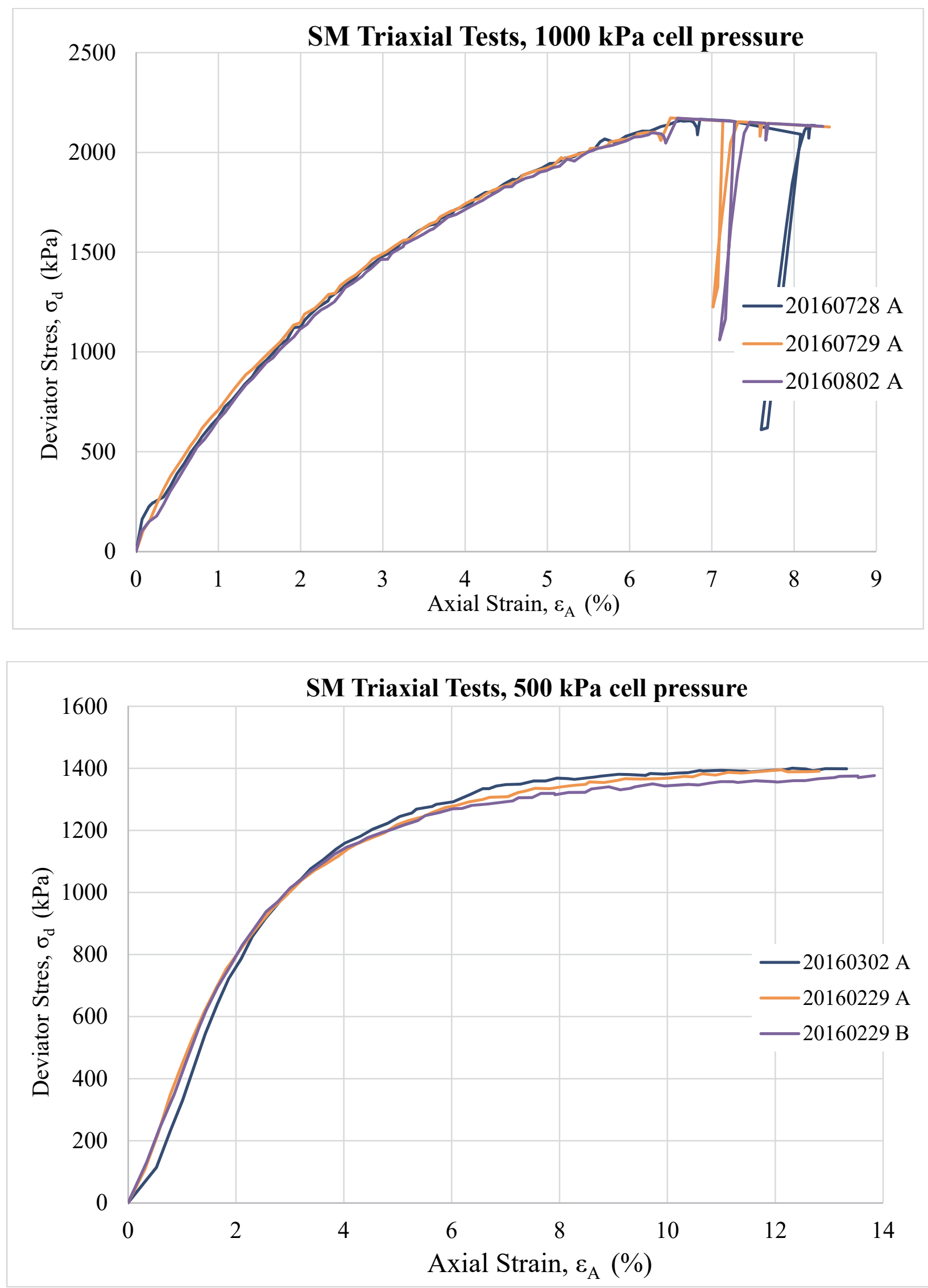

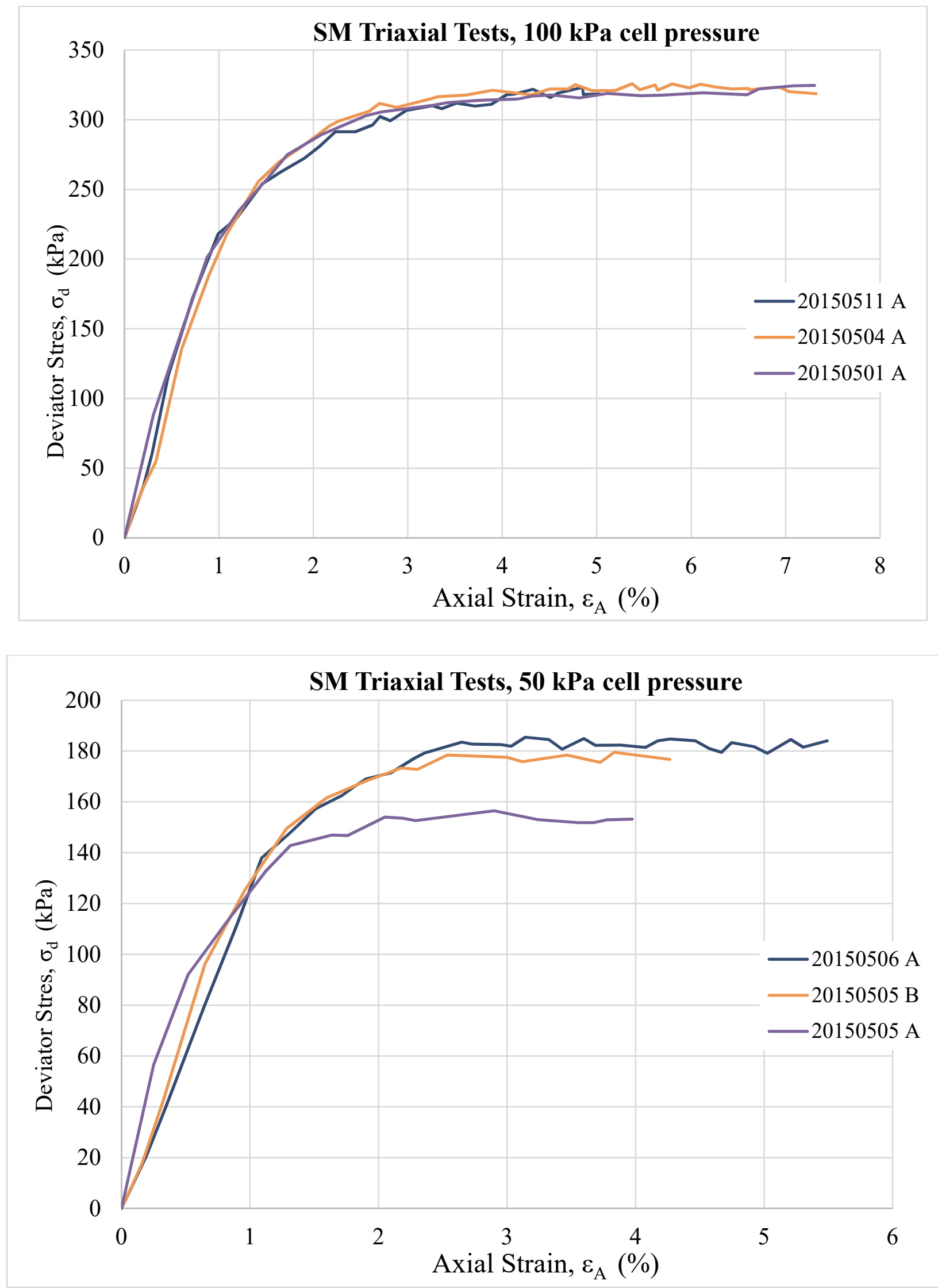

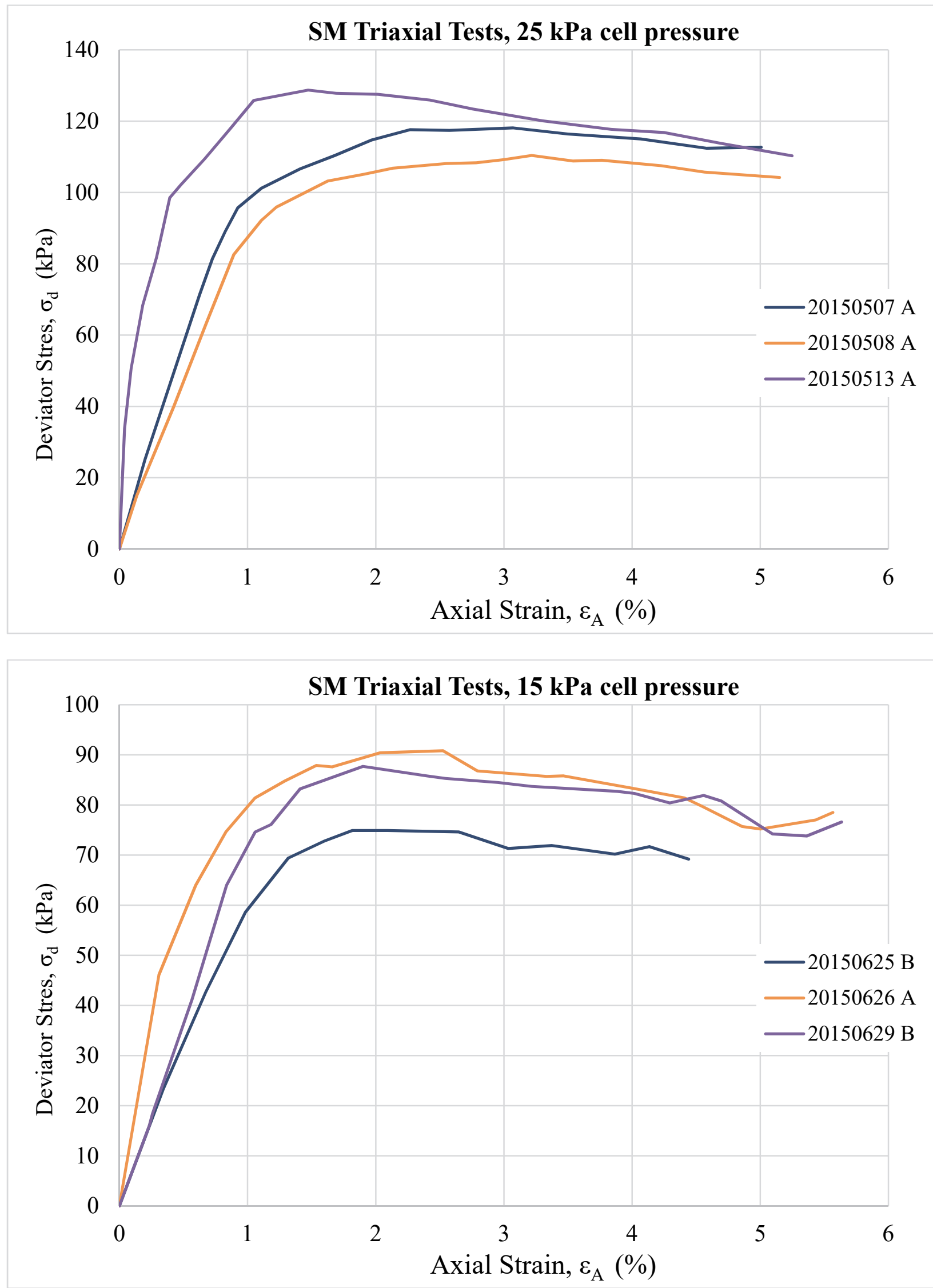

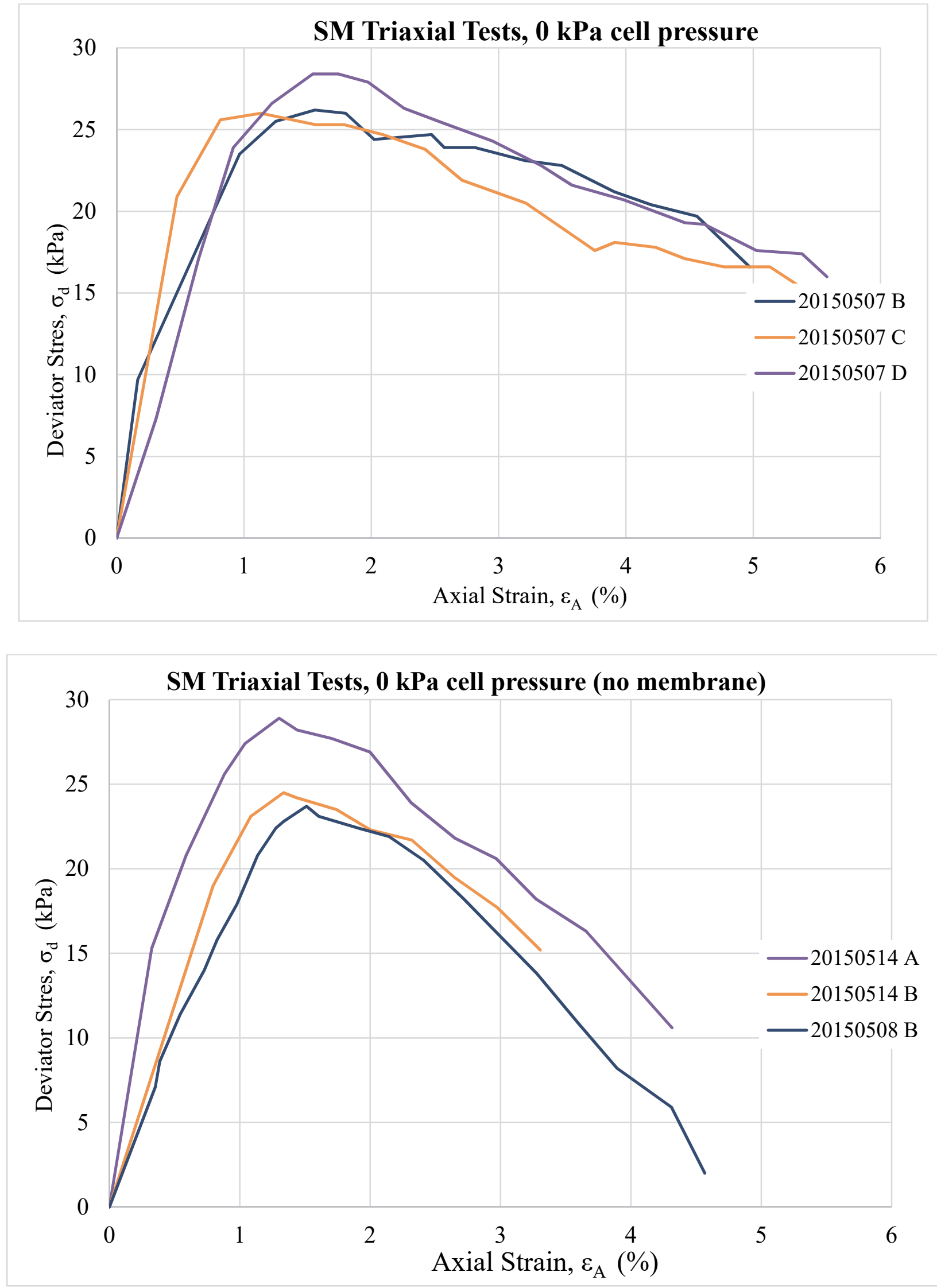
ML triaxial test data

\begin{tabular}{|c|c|c|c|}
\hline $\begin{array}{c}\text { Target } \\
\text { Cell Pressure } \\
(\mathrm{kPa})\end{array}$ & $\begin{array}{c}\text { Cell Pressure } \\
\text { at } \sigma_{d} \operatorname{Max}(\mathrm{kPa})\end{array}$ & $\begin{array}{c}\text { Maximum } \\
\text { Deviator Stress } \\
\left(\sigma_{\mathrm{d}}, \mathrm{kPa}\right)\end{array}$ & Test Name \\
\hline 1000 & 1000 & 2032 & $20151116 \mathrm{~A}$ \\
\hline 1000 & 1000 & 2056 & $20151117 A$ \\
\hline 1000 & 1000 & 1966 & $20151117 \mathrm{~B}$ \\
\hline 500 & 500 & 1249 & $20151109 A$ \\
\hline 500 & 500 & 1182 & 20151109 B \\
\hline 500 & 500 & 1244 & $20151113 A$ \\
\hline 100 & 100 & 393 & $20151103 A$ \\
\hline 100 & 100 & 368 & $20151104 \mathrm{~A}$ \\
\hline 100 & 100 & 370 & $20151104 B$ \\
\hline 50 & 50 & 237 & $20151105 \mathrm{~A}$ \\
\hline 50 & 52 & 264 & $20151105 B$ \\
\hline 50 & 51 & 240 & $20151106 A$ \\
\hline 25 & 27 & 211 & $20151110 \mathrm{~A}$ \\
\hline 25 & 26 & 205 & $20151110 \mathrm{~B}$ \\
\hline 25 & 27 & 187 & $20151112 \mathrm{~B}$ \\
\hline 15 & 15 & 157 & $20151123 \mathrm{~A}$ \\
\hline 15 & 16 & 162 & $20151124 \mathrm{~A}$ \\
\hline 15 & 17 & 156 & $20151124 B$ \\
\hline 0 & 0 & 106 & $20151028 \mathrm{~A}$ \\
\hline 0 & 0 & 89 & $20151130 \mathrm{~B}$ \\
\hline 0 & 0 & 112 & $20151201 \mathrm{~A}$ \\
\hline
\end{tabular}





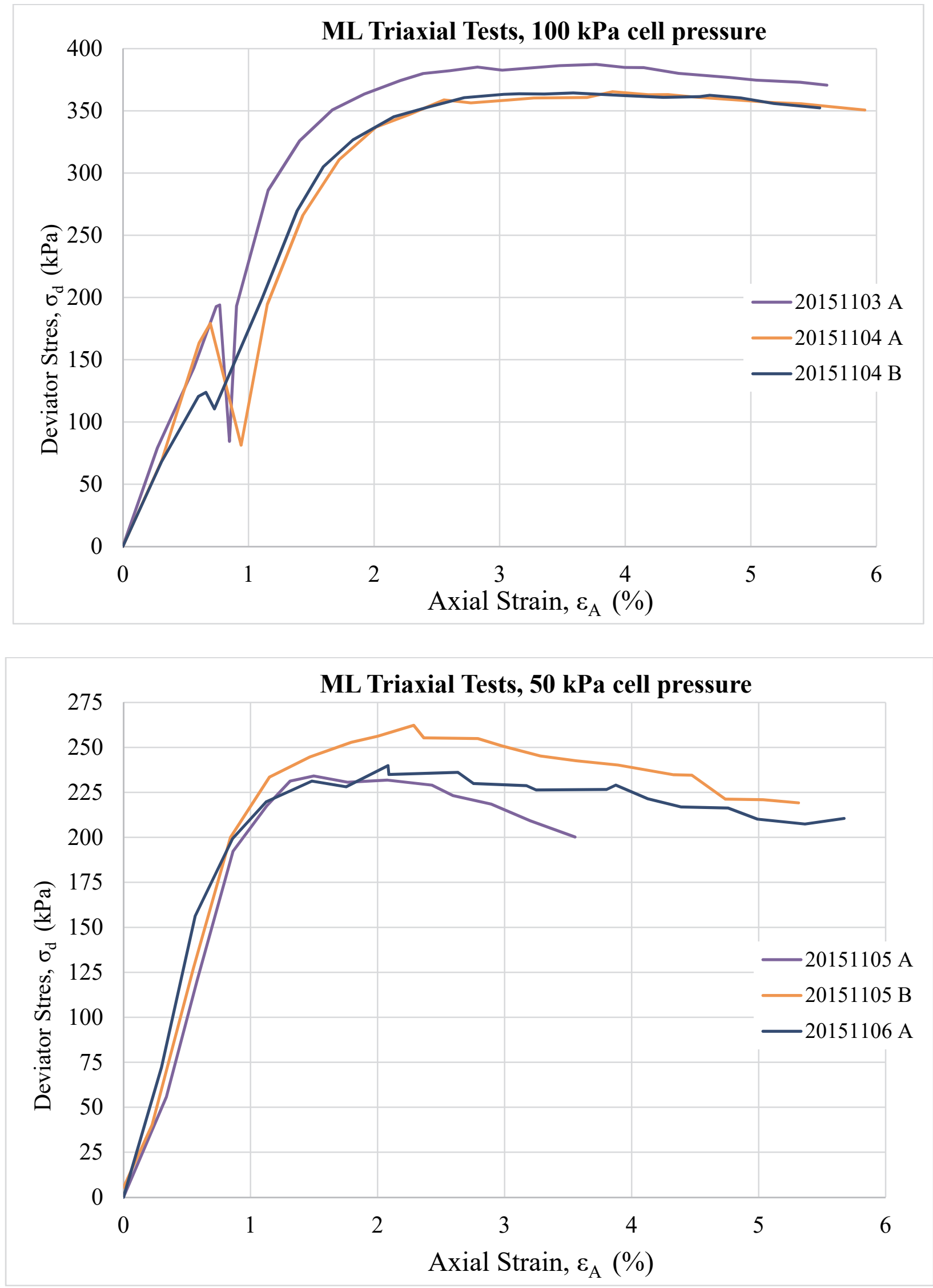

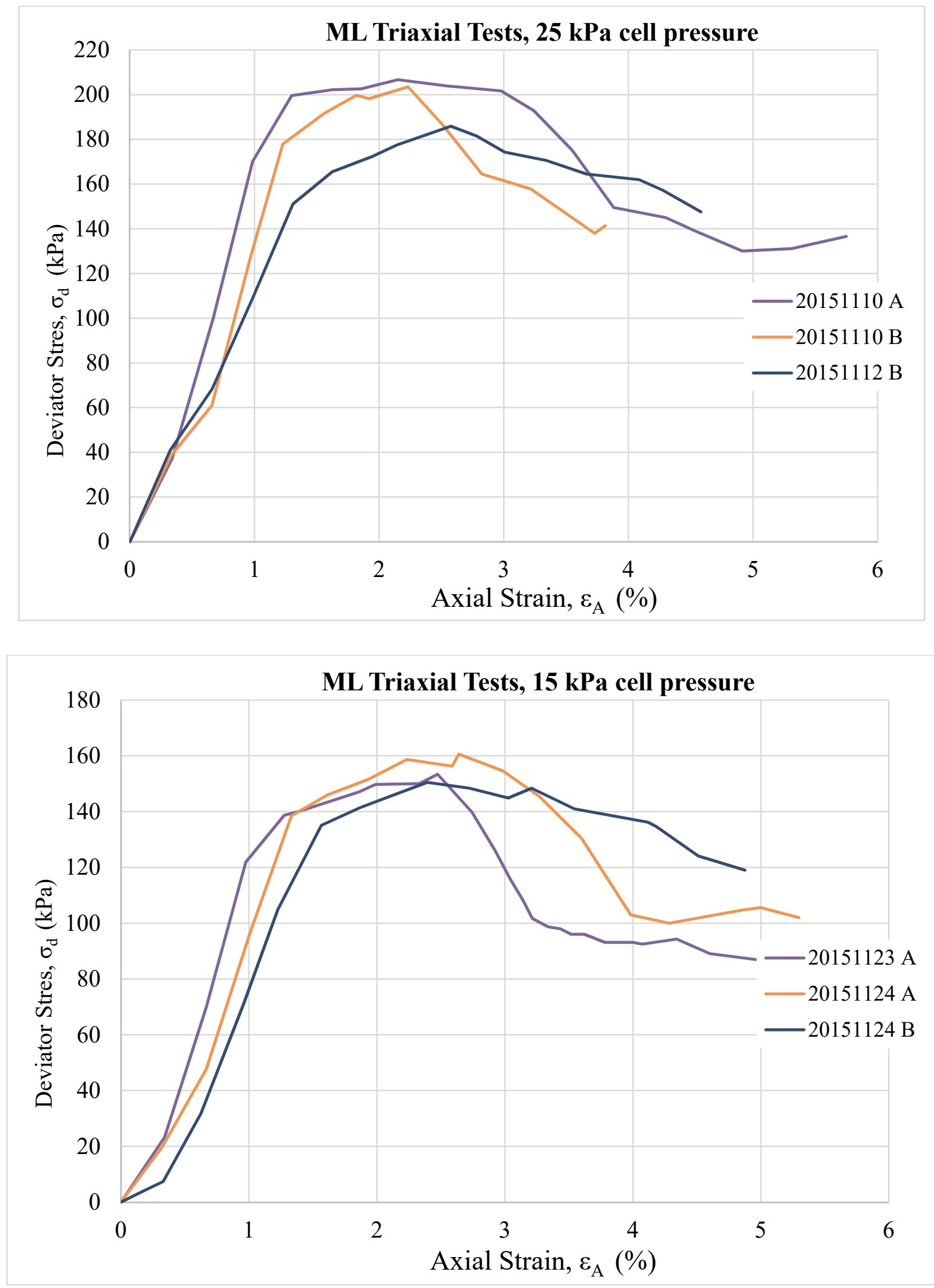


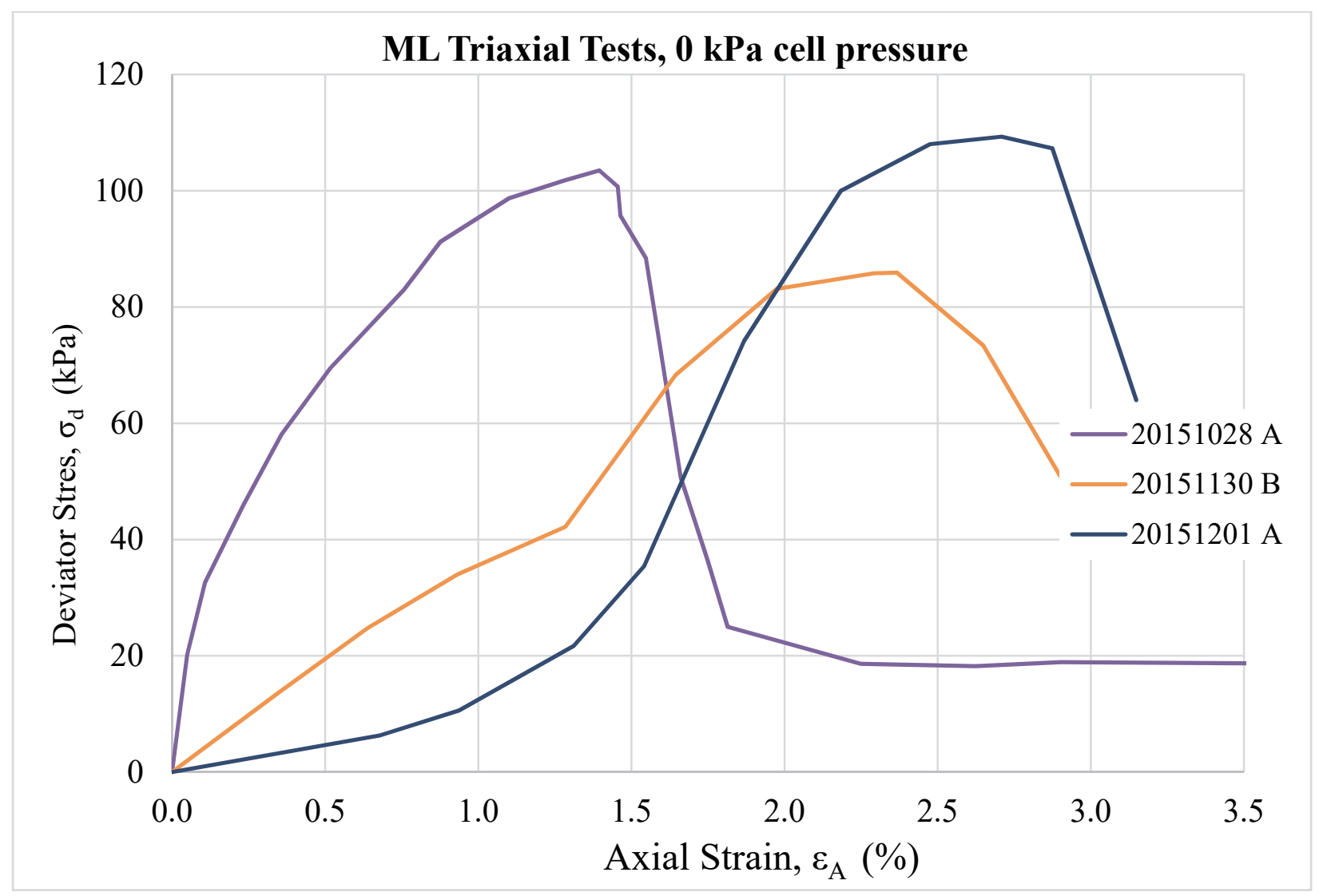




\section{Simple shear test data}

SP simple shear test data

\begin{tabular}{|c|c|c|}
\hline $\begin{array}{c}\text { Cell } \\
\text { Pressure } \\
(\mathrm{kPa})\end{array}$ & $\begin{array}{c}\text { Shear Stress } \\
\text { at Failure t } \\
(\mathrm{kPa})\end{array}$ & Test Name \\
\hline 500 & 307.9 & 20160427 aCP500 \\
\hline 500 & 300.9 & $20160428 \mathrm{aCP} 500$ \\
\hline 500 & 307.0 & $20160519 a C P 500$ \\
\hline 250 & 174.1 & $20160127 a C P 250$ \\
\hline 250 & 173.8 & $20160128 \mathrm{aCP} 250$ \\
\hline 250 & 180.0 & $20160201 a C P 250$ \\
\hline 100 & 62.6 & Jan27B \\
\hline 100 & 66.6 & $\operatorname{Jan} 28 \mathrm{~A}$ \\
\hline 100 & 64.9 & Jan30A \\
\hline 75 & 57.0 & $20150721 \mathrm{CP} 75$ \\
\hline 75 & 59.5 & 20150819aСР75 \\
\hline 75 & 55.3 & $20150724 C P 75$ \\
\hline 50 & 48.0 & $20150722 a C P 50$ \\
\hline 50 & 42.3 & $20150819 b C P 50$ \\
\hline 50 & 45.9 & 20150924 bCР50 \\
\hline 25 & 21.0 & 20150722 bCP25 \\
\hline 25 & 25.6 & $20150914 a C P 25$ \\
\hline 25 & 23.6 & $20150922 a \mathrm{CP} 25$ \\
\hline 15 & 17.6 & 20160406CР15 \\
\hline 15 & 13.8 & 20160407 CP15 \\
\hline 15 & 17.0 & 20160414 СР15 \\
\hline 0 & 6.2 & $20150924 c D 5$ \\
\hline 0 & 8.1 & $20150928 a D 5$ \\
\hline 0 & 8.0 & $20150928 b D 5$ \\
\hline 0 & 5.6 & 20150918aD2 \\
\hline 0 & 6.9 & 20150918bD2 \\
\hline 0 & 7.3 & 20150924aD2 \\
\hline
\end{tabular}



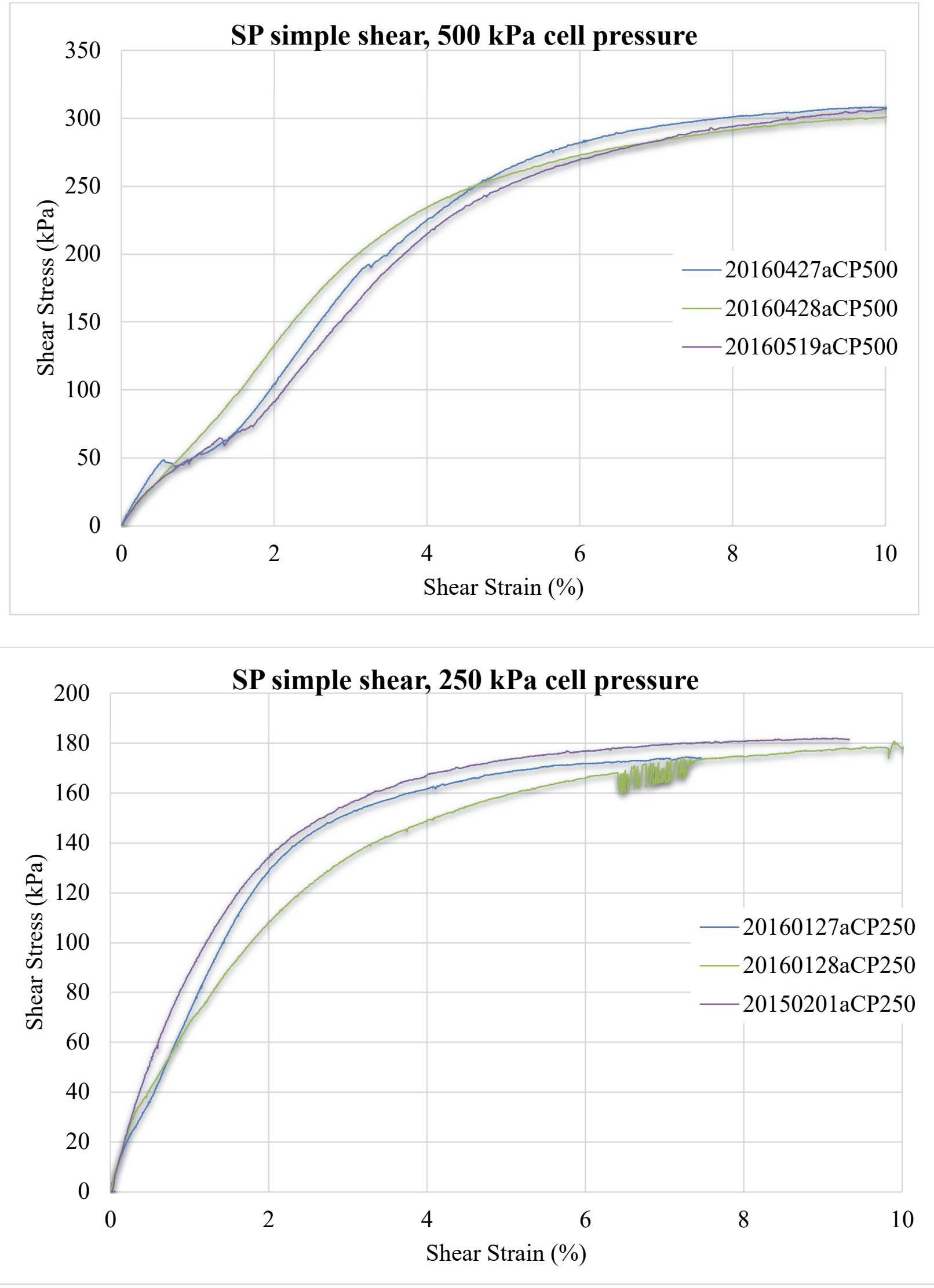

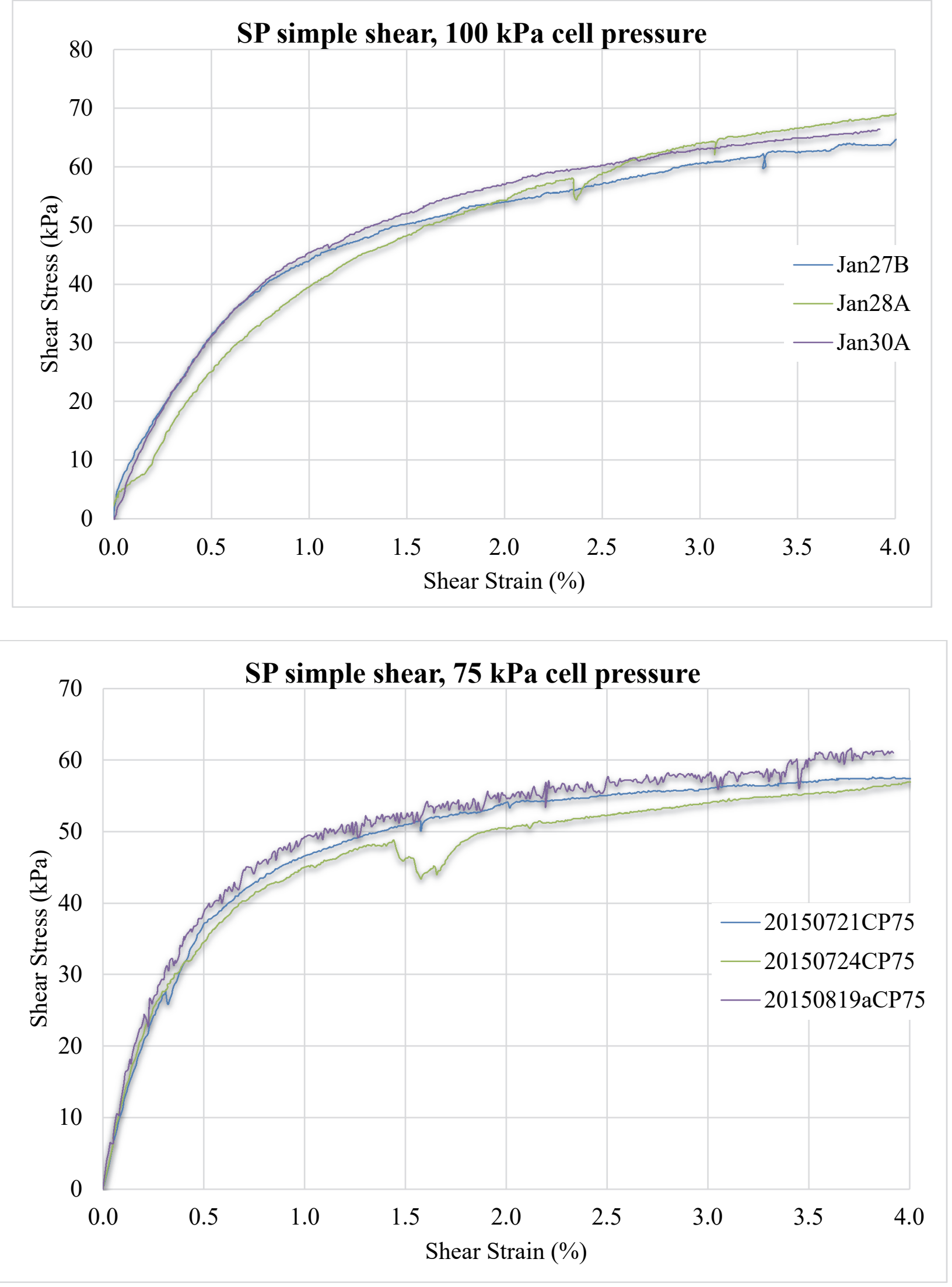

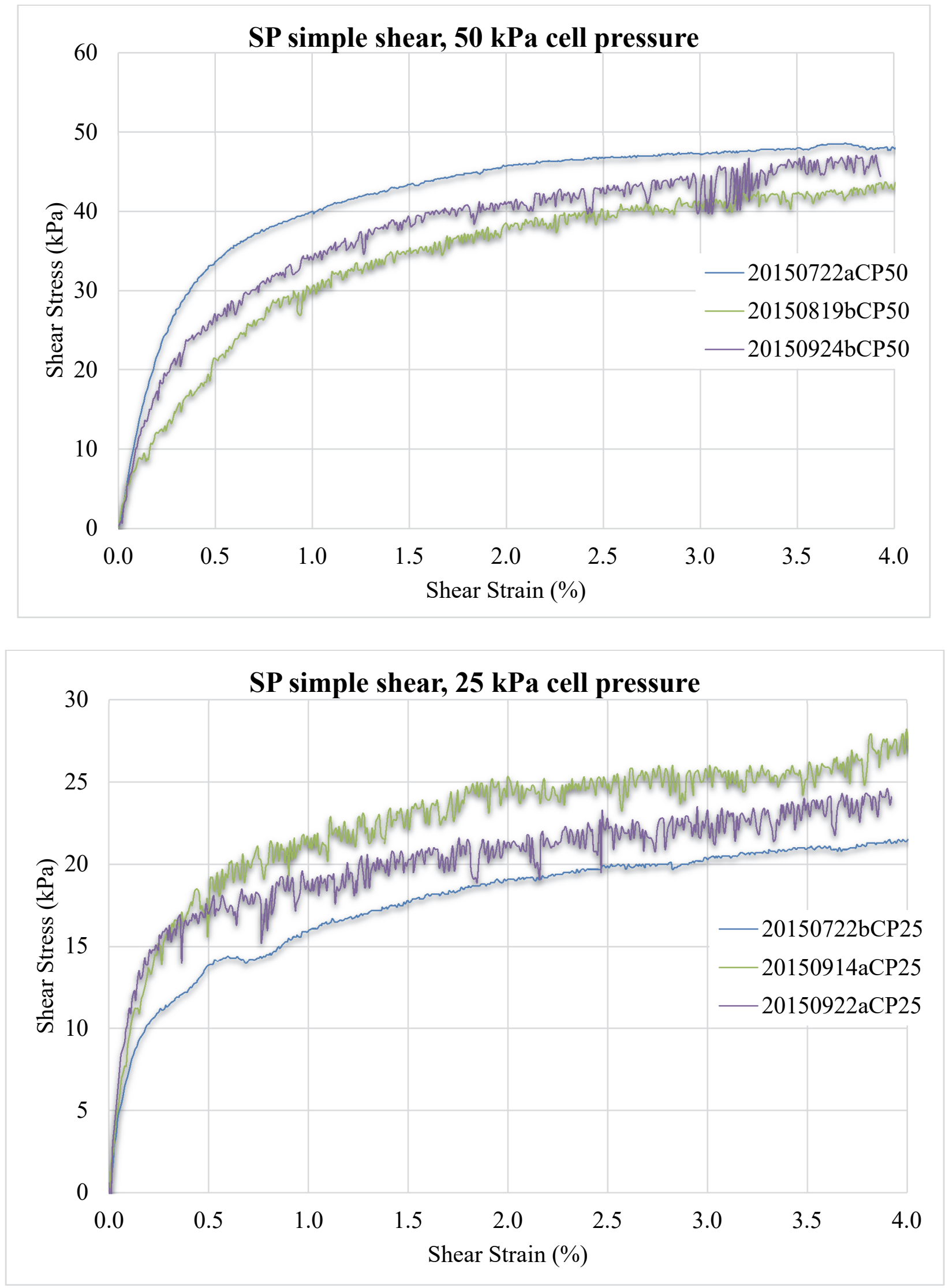

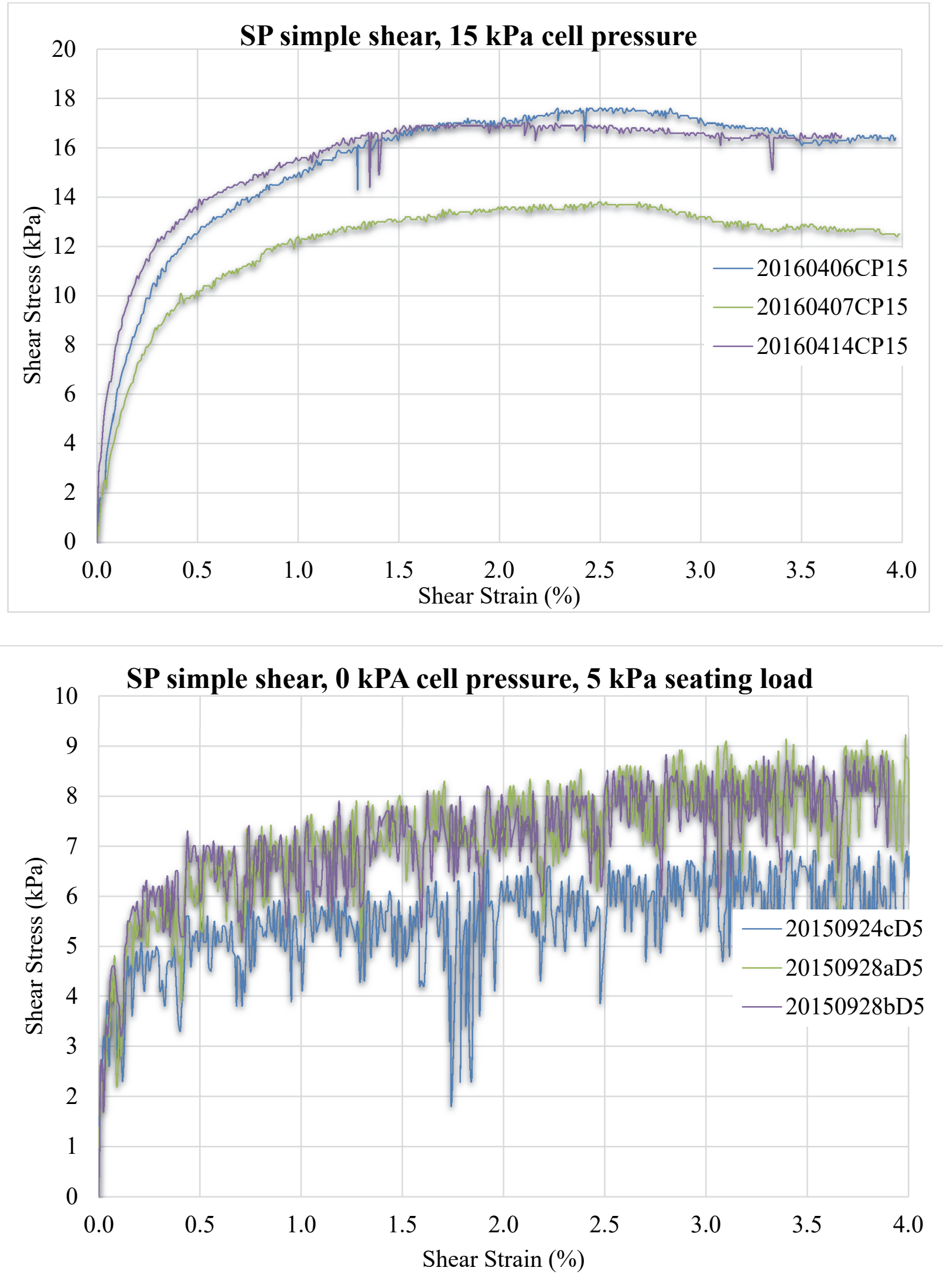


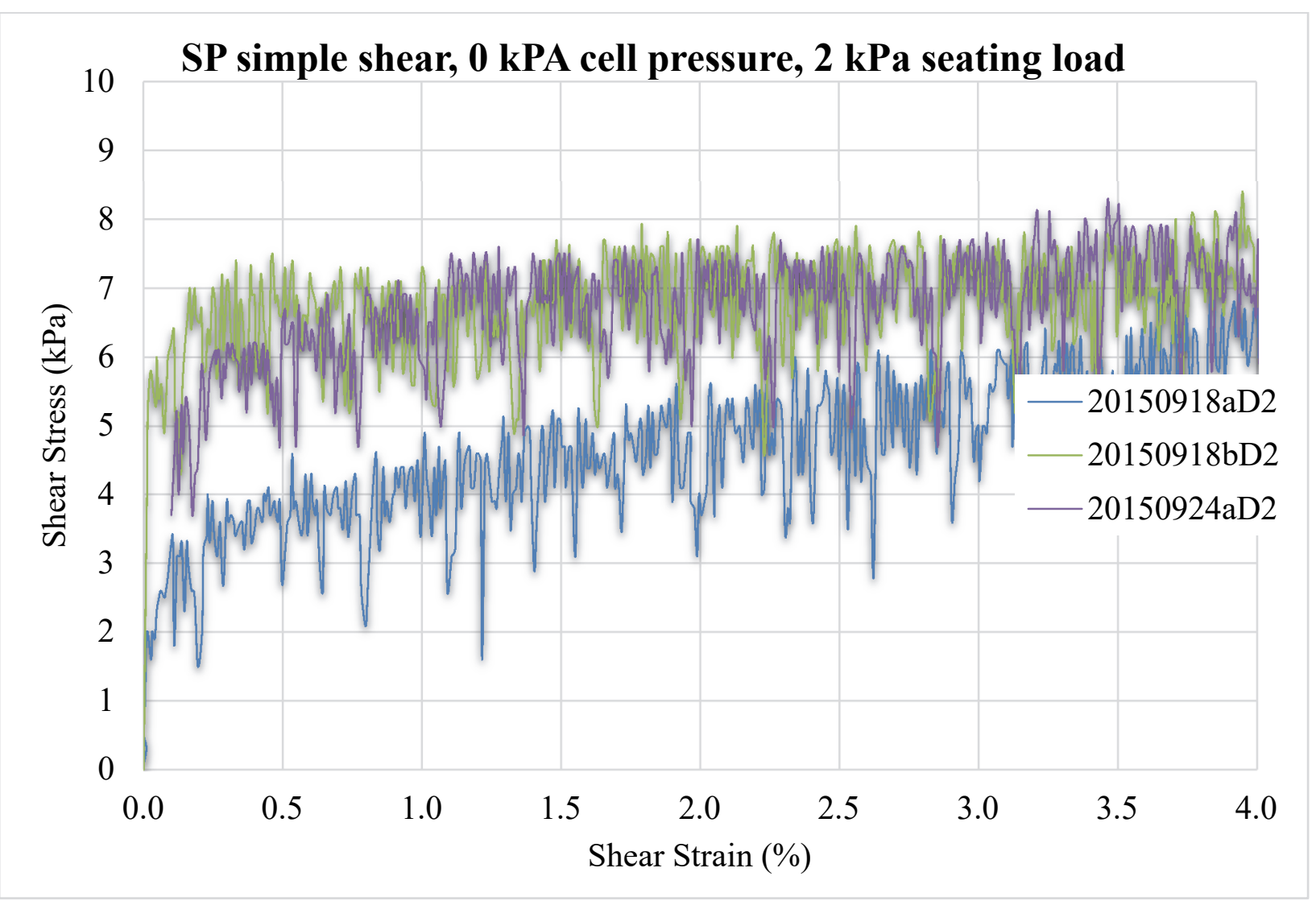


SM simple shear test data

\begin{tabular}{|c|c|c|}
\hline $\begin{array}{c}\text { Cell } \\
\text { Pressure } \\
(\mathrm{kPa})\end{array}$ & $\begin{array}{l}\text { Shear Stress at } \\
\text { Failure } \mathrm{T}(\mathrm{kPa})\end{array}$ & Test Name \\
\hline 500 & 300.8 & 20160211bCP500 \\
\hline 500 & 299.1 & $20160212 a C P 500$ \\
\hline 500 & 301.8 & $20160217 a C P 500$ \\
\hline 250 & 164.7 & 20160202aCP250 \\
\hline 250 & 158.4 & $20160209 a C P 250$ \\
\hline 250 & 155.9 & $20160211 a C P 250$ \\
\hline 100 & 64.6 & $20150316 c C P 100$ \\
\hline 100 & 65.3 & $20150318 b C P 100$ \\
\hline 100 & 63.3 & $20150323 a \mathrm{aCP} 100$ \\
\hline 75 & 53.2 & $20150622 b C P 75$ \\
\hline 75 & 54.9 & 20150622cСР75 \\
\hline 75 & 57.4 & $20150623 а \mathrm{CP} 75$ \\
\hline 50 & 36.6 & 20150312cCP50 \\
\hline 50 & 37.8 & $20150318 c C P 50$ \\
\hline 50 & 43.5 & 20150319cСР50 \\
\hline 25 & 33.6 & $20150312 a C P 25$ \\
\hline 25 & 32.8 & $20150312 b C P 25$ \\
\hline 25 & 27.5 & $20150318 a C P 25$ \\
\hline 15 & 23.6 & $20150617 a \mathrm{aCP} 15$ \\
\hline 15 & 21.4 & $20150618 a \mathrm{CP} 15$ \\
\hline 15 & 22.6 & $20150618 b C P 15$ \\
\hline 0 & 8.9 & 20150318aCPOd5 \\
\hline 0 & 10.5 & 20150324aCPOd5 \\
\hline 0 & 13.0 & 20150324bCPOd5 \\
\hline 0 & 9.4 & $20150319 b C P O d 2$ \\
\hline 0 & 8.1 & 20150320bCPOd2 \\
\hline 0 & 8.9 & 20150323bCPOd2 \\
\hline
\end{tabular}




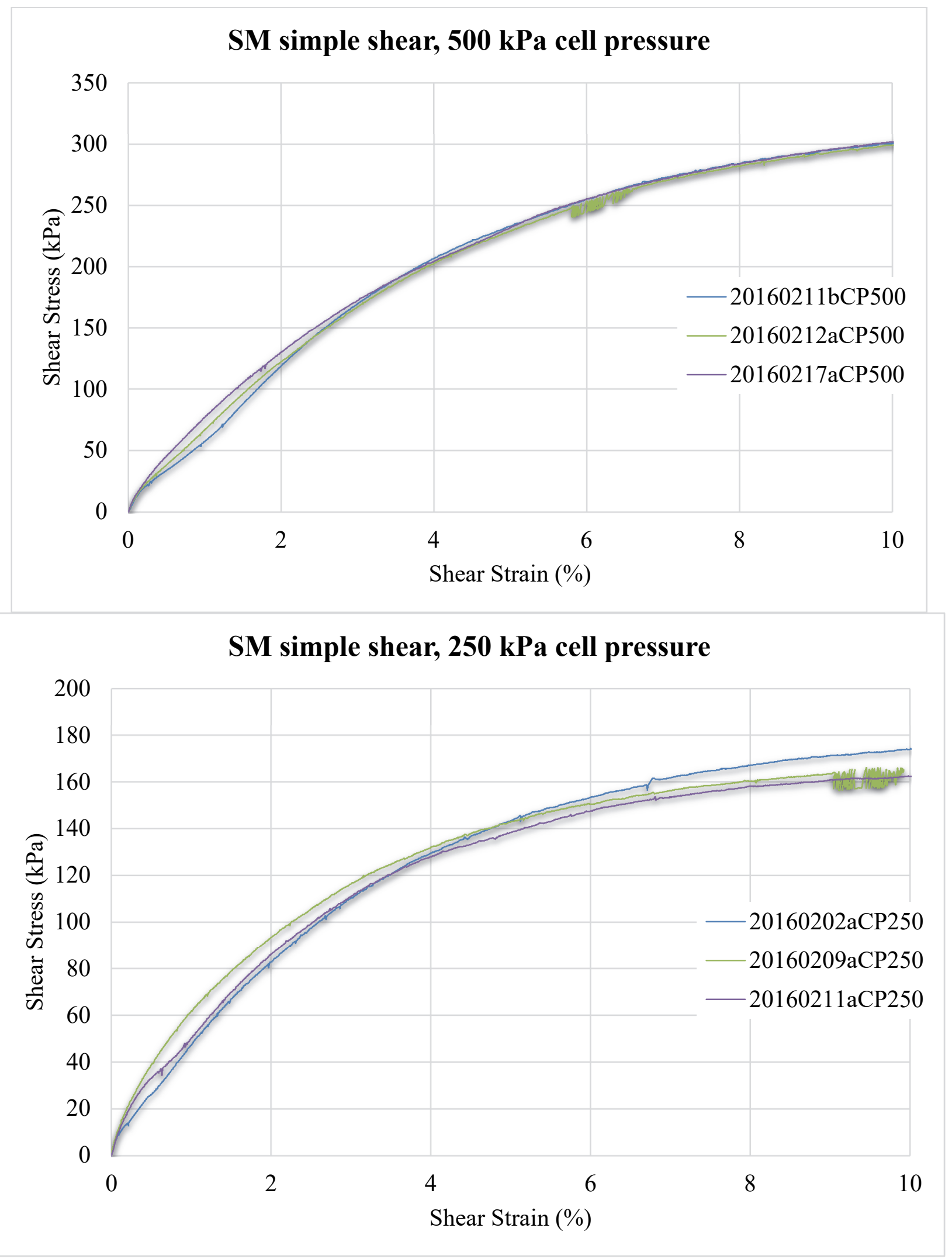




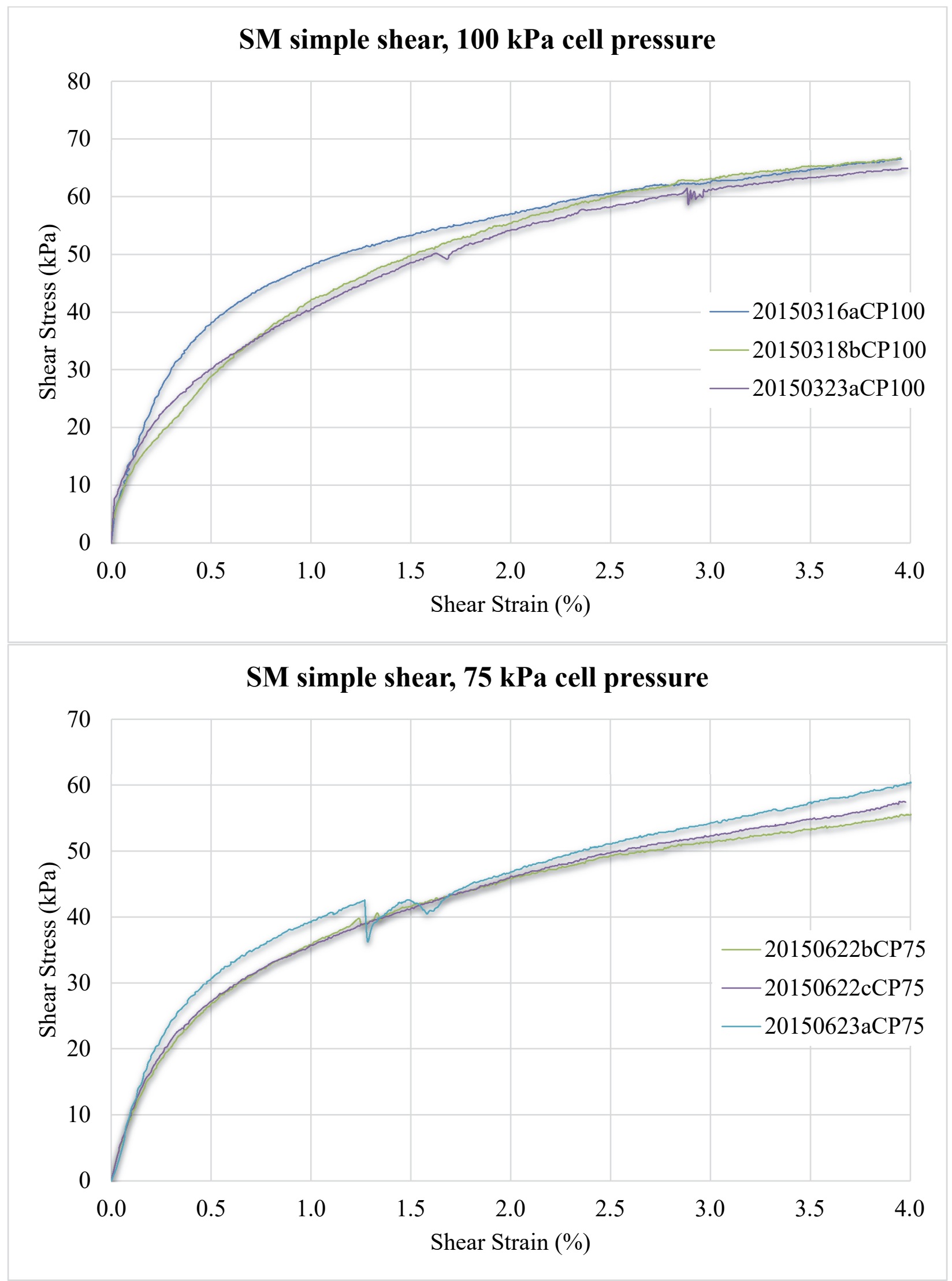




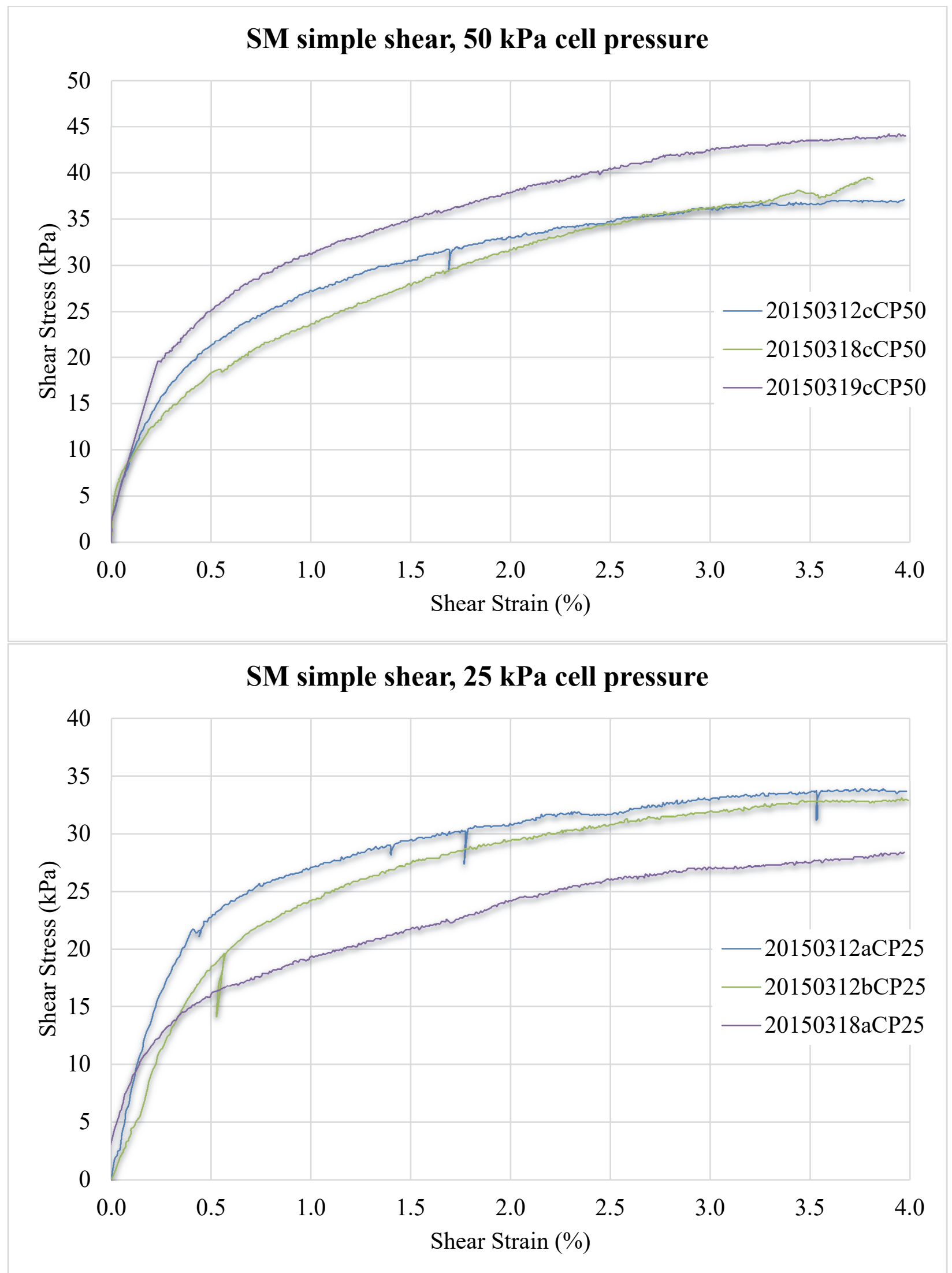




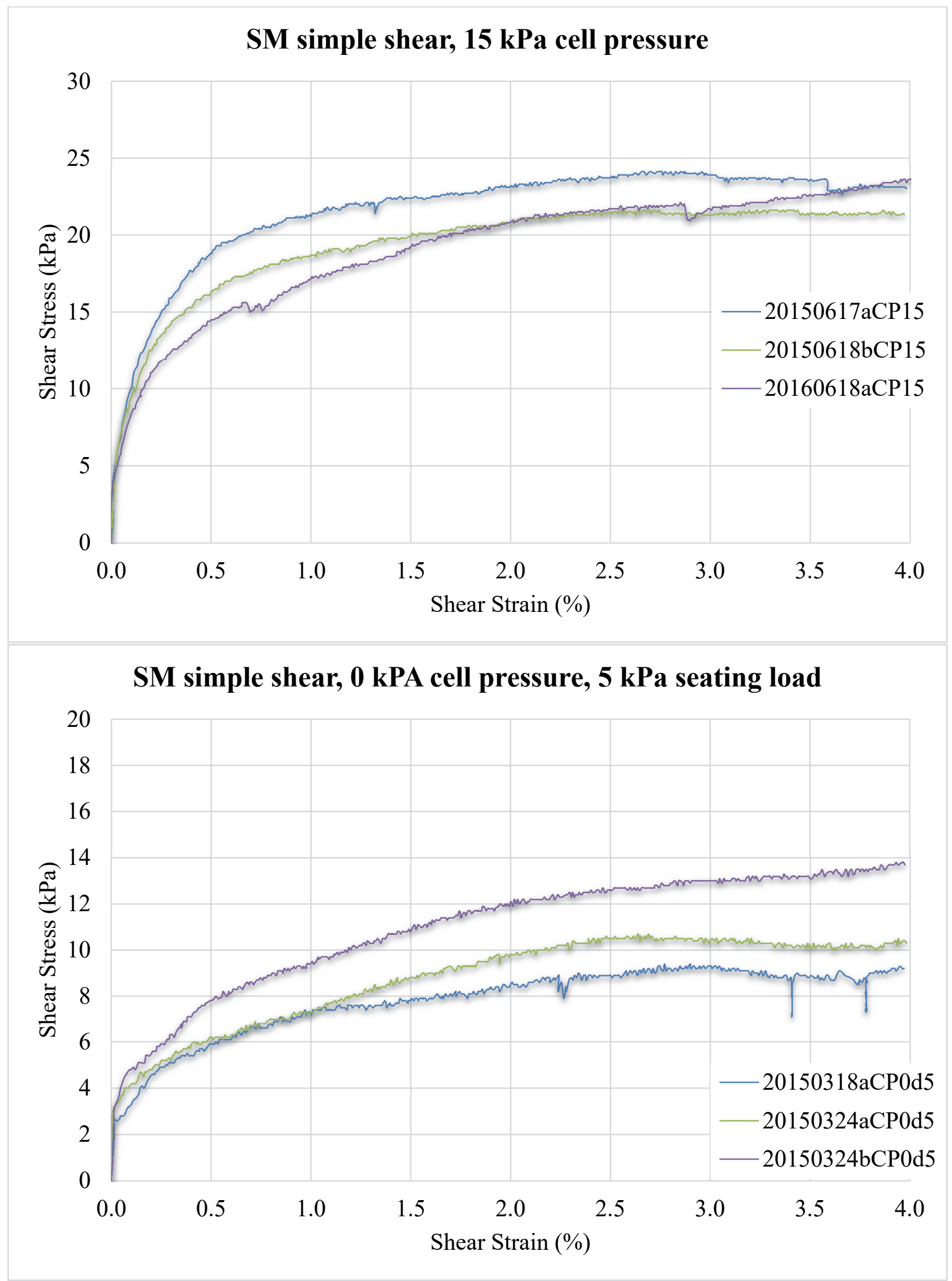




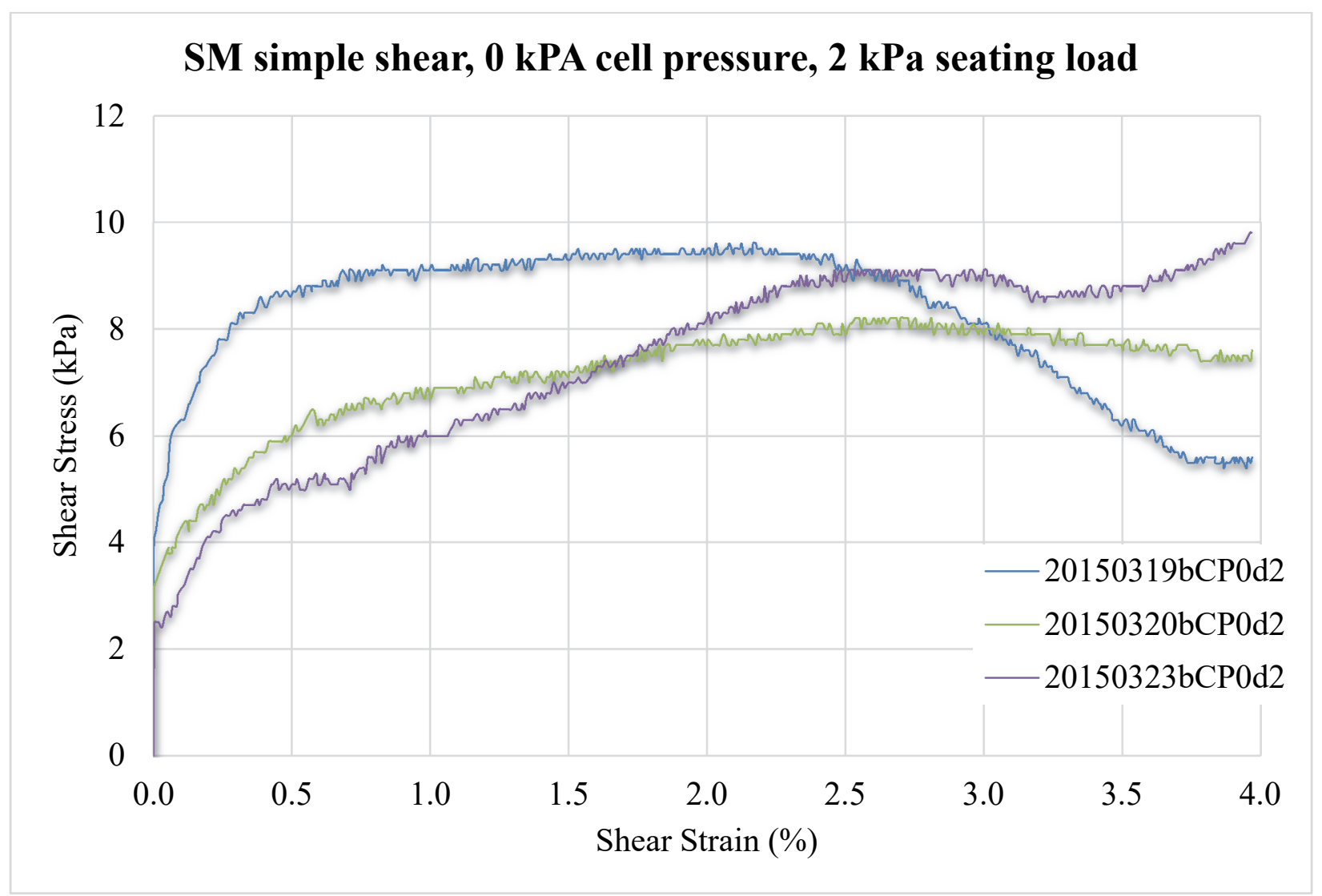


ML simple shear test data

\begin{tabular}{|c|c|c|}
\hline $\begin{array}{c}\text { Cell } \\
\text { Pressure } \\
(\mathrm{kPa})\end{array}$ & $\begin{array}{c}\text { Shear Stress } \\
\text { at Failure } \mathrm{T} \\
(\mathrm{kPa})\end{array}$ & Test Name \\
\hline 500 & 264.0 & $20160222 b C P 500$ \\
\hline 500 & 261.0 & $20160223 a$ СР500 \\
\hline 500 & 273.4 & $20160225 a C P 500$ \\
\hline 250 & 142.1 & $20160225 b C P 250$ \\
\hline 250 & 145.4 & $20160226 a C P 250$ \\
\hline 250 & 138.2 & $20160301 \mathrm{aCP} 250$ \\
\hline 100 & 55.4 & $20151007 a C P 100$ \\
\hline 100 & 57.2 & 20151007bCP100 \\
\hline 100 & 56.6 & 20151008aCP100 \\
\hline 75 & 48.2 & $20151014 a C P 75$ \\
\hline 75 & 49.4 & 20151015bCP75 \\
\hline 75 & 49.6 & $20151125 a C P 75$ \\
\hline 50 & 42.1 & 20151008bCР50 \\
\hline 50 & 38.9 & 20151019aСР50 \\
\hline 50 & 34.3 & 20151019bCР50 \\
\hline 25 & 24.4 & $20151013 a$ СР25 \\
\hline 25 & 25.8 & $20151013 b C P 25$ \\
\hline 25 & 27.7 & 20151015аСР25 \\
\hline 15 & 16.5 & $20151020 a C P 15$ \\
\hline 15 & 19.5 & 20151109bCР15 \\
\hline 15 & 21.1 & $20151215 a \mathrm{a} 15$ \\
\hline 0 & 16.1 & 20151028aCPOd5 \\
\hline 0 & 13.7 & 20151106aCPOd5 \\
\hline 0 & 13.7 & 20160809aCPOd5 \\
\hline 0 & 11.6 & 20151109aCPOd2 \\
\hline 0 & 10.9 & 20151120aCPOd2 \\
\hline 0 & 13.1 & 20160805aCPOd2 \\
\hline
\end{tabular}



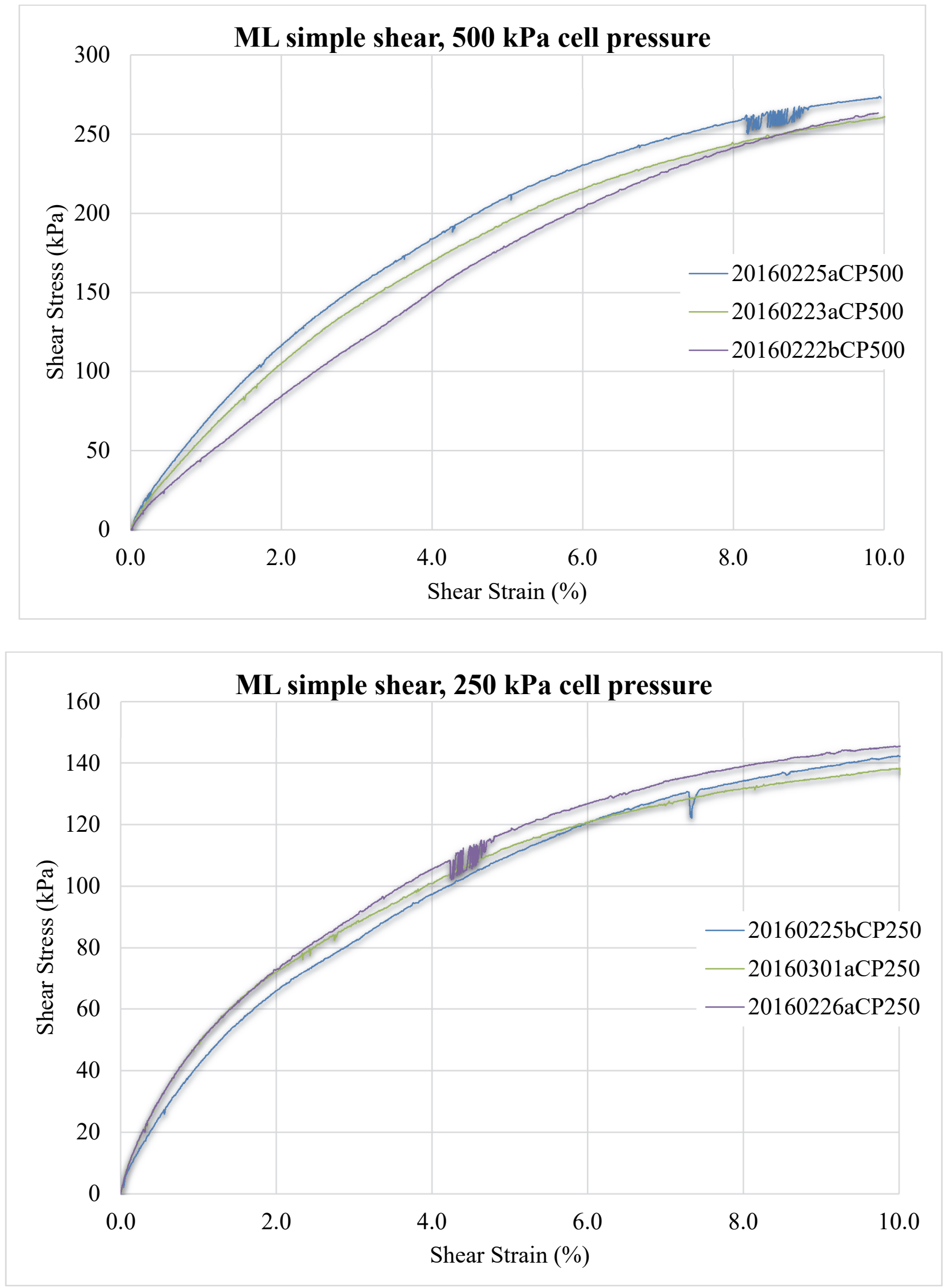

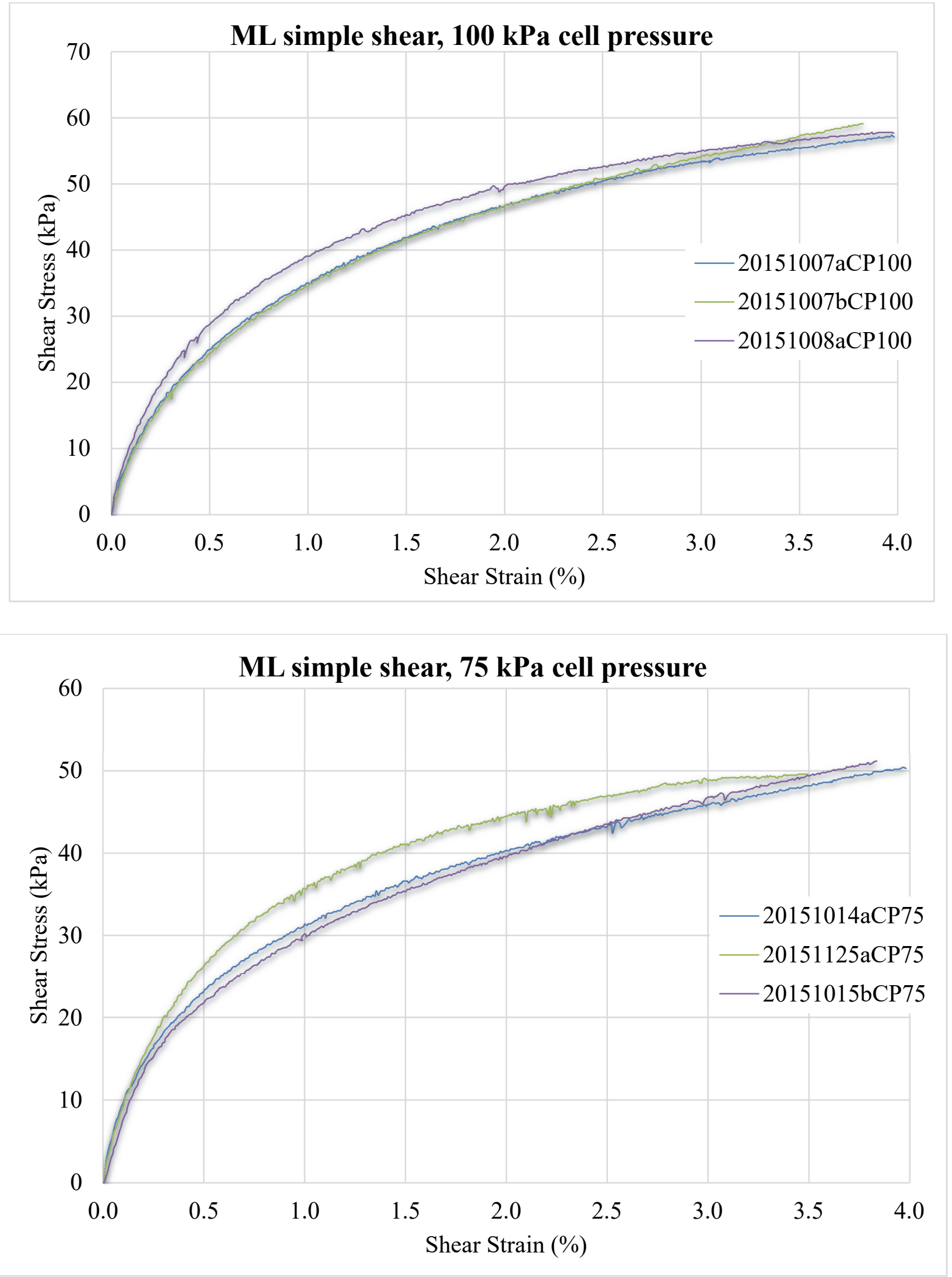

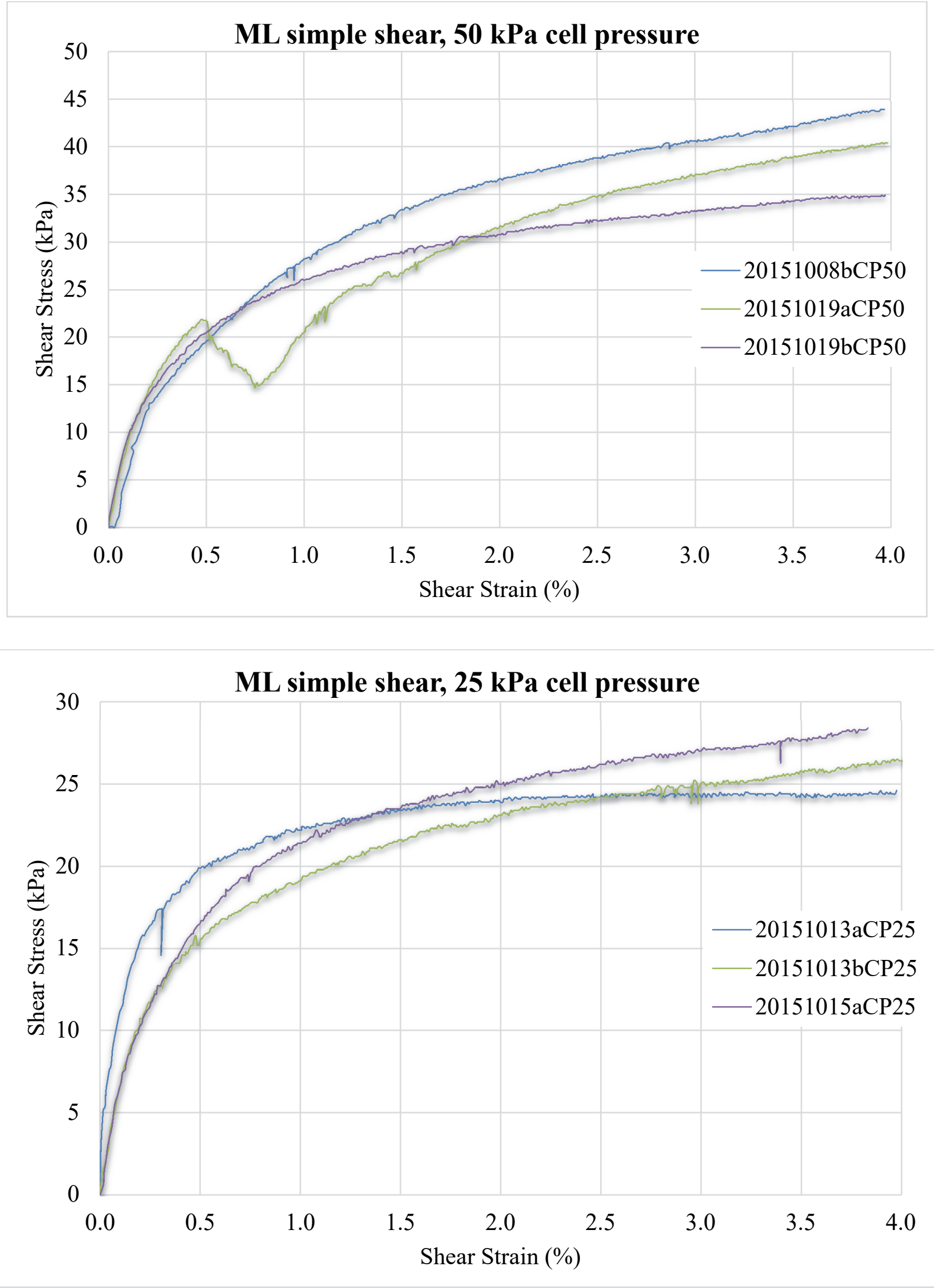

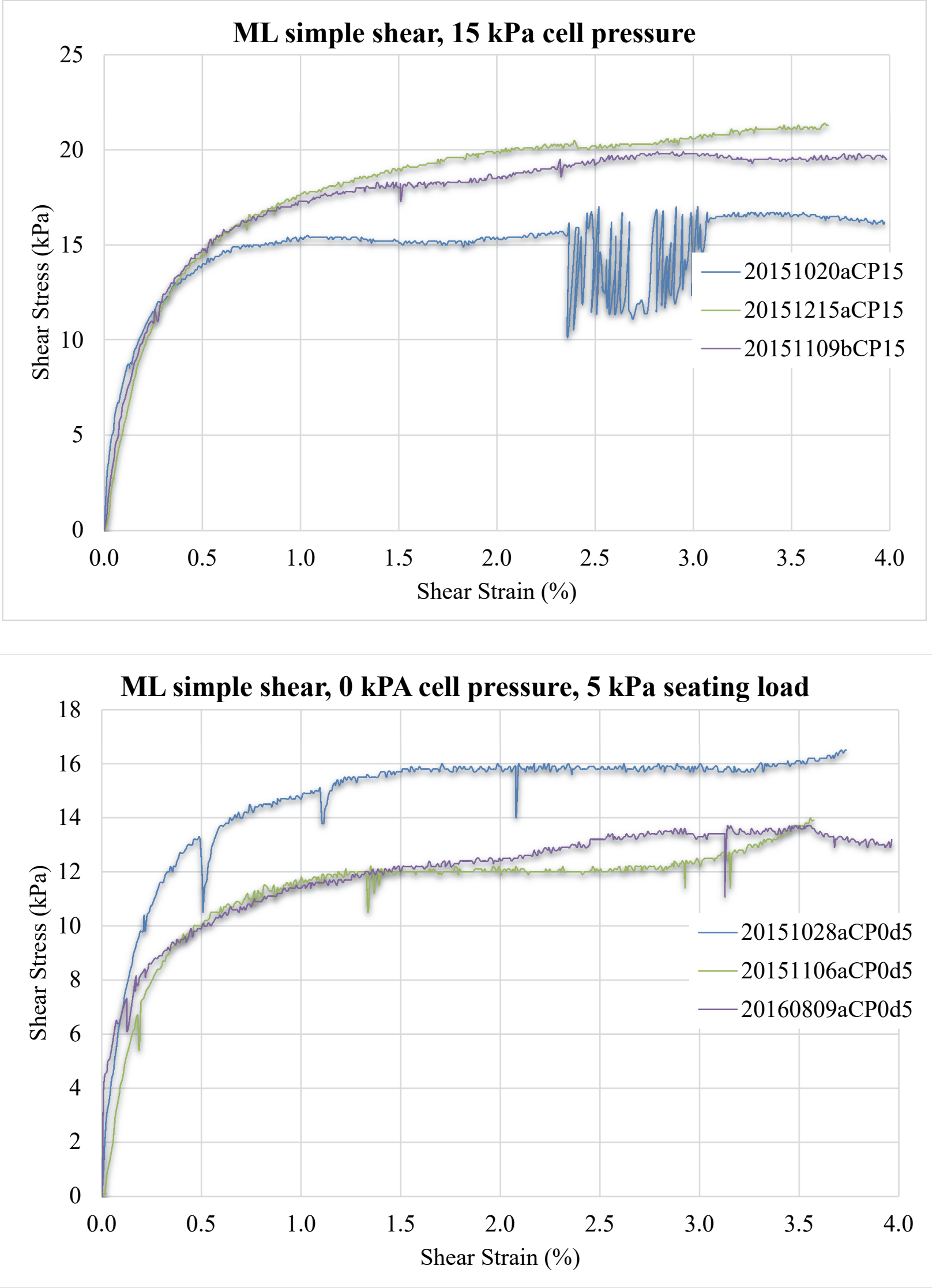


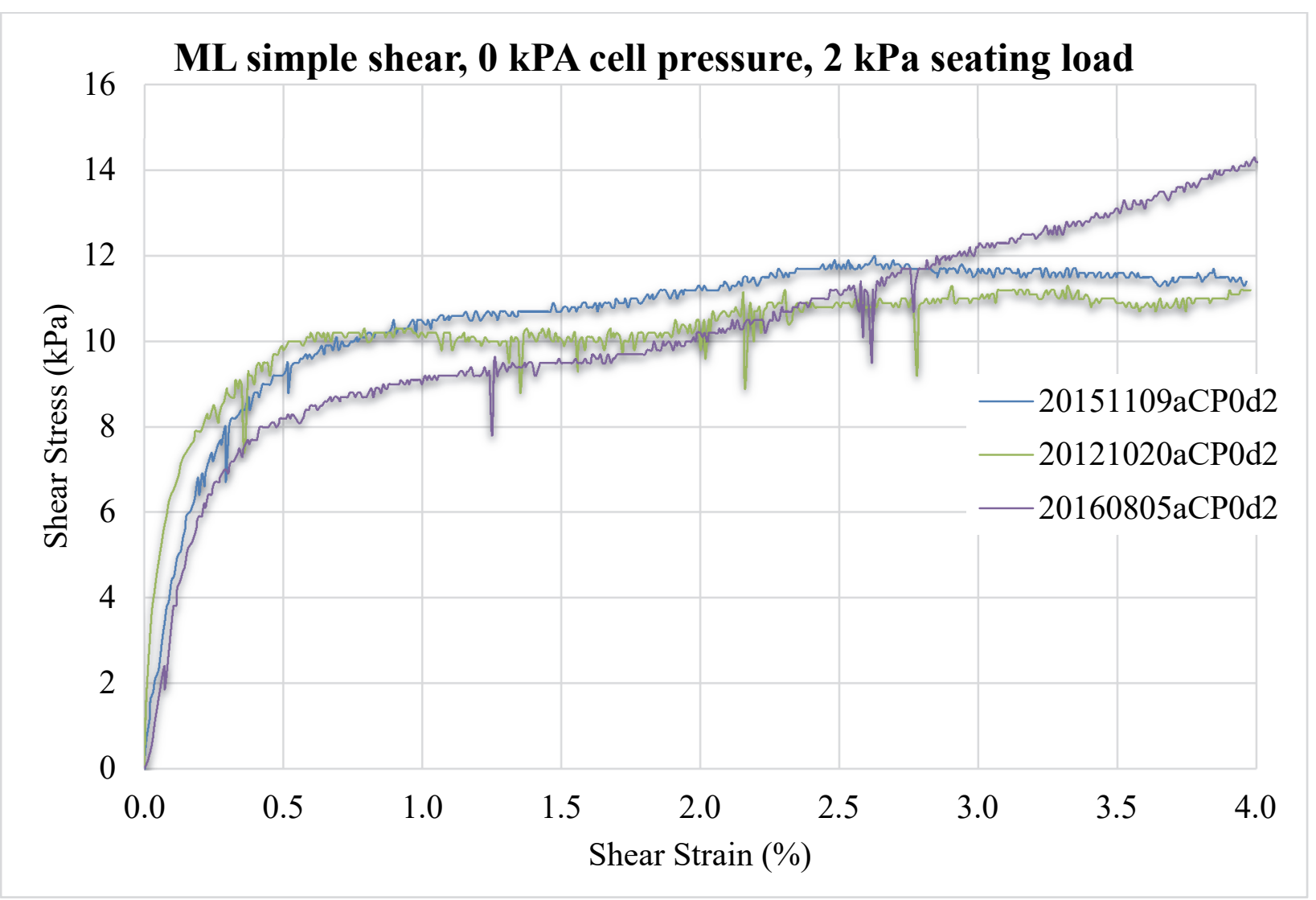




\section{SP ring shear test data}

\begin{tabular}{|c|c|c|c|c|c|c|}
\hline Specimen & $\begin{array}{c}\text { Cell } \\
\text { Pressure } \\
\text { kPa }\end{array}$ & $\begin{array}{l}\text { Shear } \\
\text { Stress at } \\
\text { failure } \\
\mathrm{kPa}\end{array}$ & $\begin{array}{c}\text { Cyclic } \\
\text { Strain at } \\
\text { failure } \\
\%\end{array}$ & $\begin{array}{c}\text { Failure } \\
\text { Cycle }\end{array}$ & $\begin{array}{l}\text { Shear } \\
\text { Stress at } \\
\text { critical } \\
\text { state } \\
\text { kPa }\end{array}$ & $\begin{array}{c}\text { Cyclic } \\
\text { Strain at } \\
\text { critical } \\
\text { state } \\
\%\end{array}$ \\
\hline CP100-A & 100 & 88.52 & 0.21264 & 4 & 100.45 & 0.20983 \\
\hline CP100-B & 100 & 90.10 & 0.21231 & 4 & 102.94 & 0.20967 \\
\hline CP100-C & 100 & 89.83 & 0.21217 & 4 & 102.55 & 0.20967 \\
\hline CP100-D & 100 & 88.96 & 0.21225 & 3 & 103.02 & 0.20967 \\
\hline CP100-E & 100 & 87.24 & 0.21294 & 3 & 106.60 & 0.21113 \\
\hline CP100-F & 100 & 81.01 & 0.21244 & 3 & 97.07 & 0.21112 \\
\hline CP100-G & 100 & 84.70 & 0.21231 & 4 & 97.36 & 0.20967 \\
\hline CP100-H & 100 & 80.80 & 0.21242 & 4 & 93.24 & 0.20986 \\
\hline CР75-A & 75 & 66.00 & 0.21275 & 4 & 74.88 & 0.21019 \\
\hline CР75-В & 75 & 60.06 & 0.21286 & 3 & 76.99 & 0.21164 \\
\hline CP75-C & 75 & 61.53 & 0.21281 & 4 & 73.56 & 0.21019 \\
\hline CP75-D & 75 & 72.47 & 0.21292 & 4 & 79.55 & 0.21056 \\
\hline CP75-E & 75 & 72.05 & 0.21261 & 4 & 82.12 & 0.21006 \\
\hline CP75-F & 75 & 86.28 & 0.21306 & 4 & 95.88 & 0.21136 \\
\hline CP75-G & 75 & 74.08 & 0.21306 & 3 & 89.03 & 0.21156 \\
\hline CP75-H & 75 & 73.07 & 0.21256 & 4 & 83.44 & 0.20992 \\
\hline CP75-I & 75 & 76.10 & 0.21256 & 3 & 89.11 & 0.21144 \\
\hline CP75-J & 75 & 71.88 & 0.21275 & 4 & 79.99 & 0.21017 \\
\hline CP50-A & 50 & 54.83 & 0.21289 & 4 & 64.18 & 0.21044 \\
\hline CP50-B & 50 & 43.90 & 0.21311 & 3 & 56.75 & 0.21036 \\
\hline СР50-C & 50 & 43.90 & 0.21311 & 4 & 62.11 & 0.21044 \\
\hline CP50-D & 50 & 50.32 & 0.21292 & 4 & 58.31 & 0.21036 \\
\hline CР50-E & 50 & 49.00 & 0.21308 & 4 & 55.09 & 0.21050 \\
\hline CP50-F & 50 & 52.84 & 0.21292 & 3 & 66.65 & 0.21031 \\
\hline CP25-A & 25 & 28.51 & 0.21375 & 4 & 38.21 & 0.21225 \\
\hline CP25-B & 25 & 28.77 & 0.21294 & 4 & 33.75 & 0.21181 \\
\hline CP25-C & 25 & 25.11 & 0.21387 & 3 & 33.39 & 0.21108 \\
\hline CP25-D & 25 & 37.63 & 0.21331 & 3 & 41.14 & 0.21075 \\
\hline CP25-E & 25 & 29.47 & 0.21350 & 4 & 34.43 & 0.21086 \\
\hline
\end{tabular}




\begin{tabular}{|l|l|l|l|l|l|l|}
\hline Specimen & $\begin{array}{c}\text { Cell } \\
\text { Pressure } \\
\mathrm{kPa}\end{array}$ & $\begin{array}{c}\text { Shear } \\
\text { Stress at } \\
\text { failure } \\
\mathrm{kPa}\end{array}$ & $\begin{array}{c}\text { Cyclic } \\
\text { Strain at } \\
\text { failure } \\
\%\end{array}$ & $\begin{array}{c}\text { Failure } \\
\text { Cycle }\end{array}$ & $\begin{array}{c}\text { Shear } \\
\text { Stress at } \\
\text { critical } \\
\text { state } \\
\mathrm{kPa}\end{array}$ & $\begin{array}{c}\text { Cyclic } \\
\text { Strain at } \\
\text { critical } \\
\text { state } \\
\%\end{array}$ \\
\hline CP25-G & 25 & 35.39 & 0.21394 & 4 & 41.83 & 0.21239 \\
\hline CP25-H & 25 & 34.40 & 0.21331 & 3 & 47.10 & 0.21075 \\
\hline CP25-I & 25 & 35.82 & 0.21325 & 3 & 43.63 & 0.21125 \\
\hline CP25-J & 25 & 30.59 & 0.21325 & 4 & 36.73 & 0.21083 \\
\hline & & & & & & \\
\hline CP10-A & 10 & 18.99 & 0.21350 & 4 & 22.95 & 0.21106 \\
\hline CP10-B & 10 & 19.26 & 0.21350 & 3 & 27.27 & 0.21244 \\
\hline CP10-C & 10 & 12.81 & 0.21400 & 3 & 17.83 & 0.21261 \\
\hline CP10-D & 10 & 18.74 & 0.21394 & 3 & 28.91 & 0.21244 \\
\hline CP10-E & 10 & 21.23 & 0.21350 & 4 & 24.31 & 0.21250 \\
\hline CP10-F & 10 & 17.33 & 0.21350 & 3 & 21.19 & 0.21250 \\
\hline CP10-G & 10 & 16.16 & 0.21325 & 5 & 20.87 & 0.21111 \\
\hline CP10-H & 10 & 26.74 & 0.21331 & 4 & 34.32 & 0.21089 \\
\hline CP10-I & 10 & 13.66 & 0.21400 & 4 & 19.30 & 0.21114 \\
\hline
\end{tabular}


ERDC/GSL TR-18-22

63
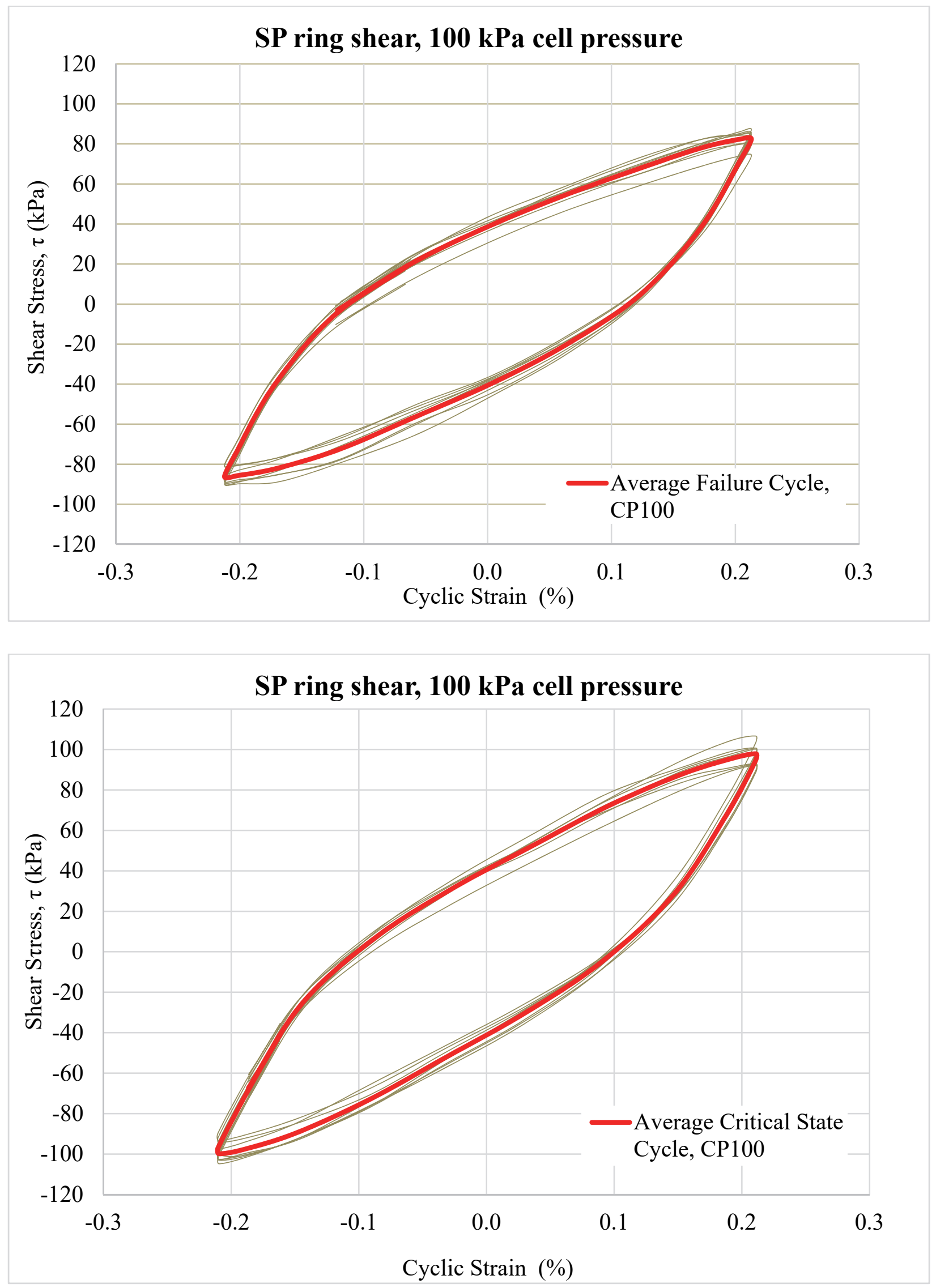

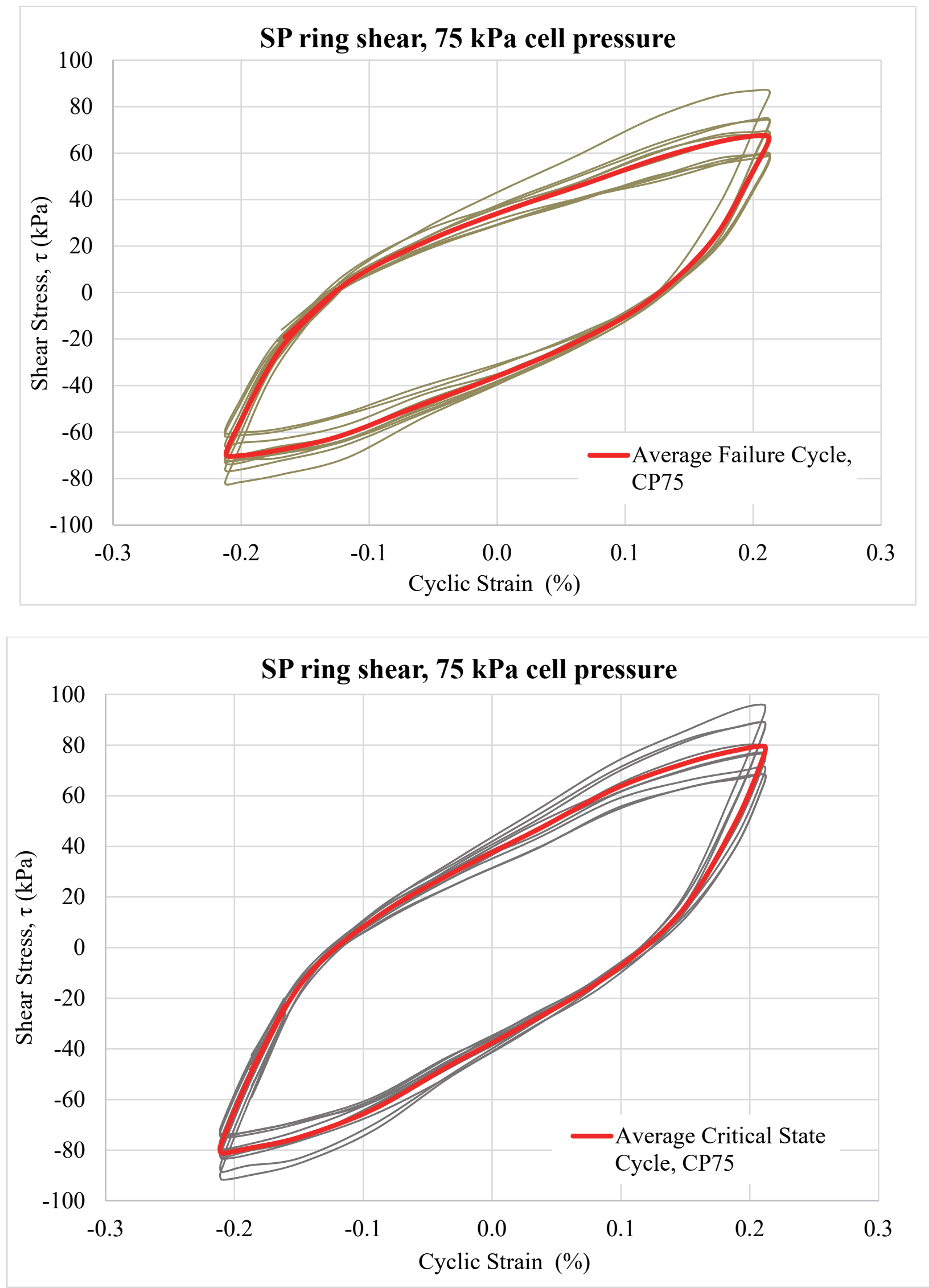

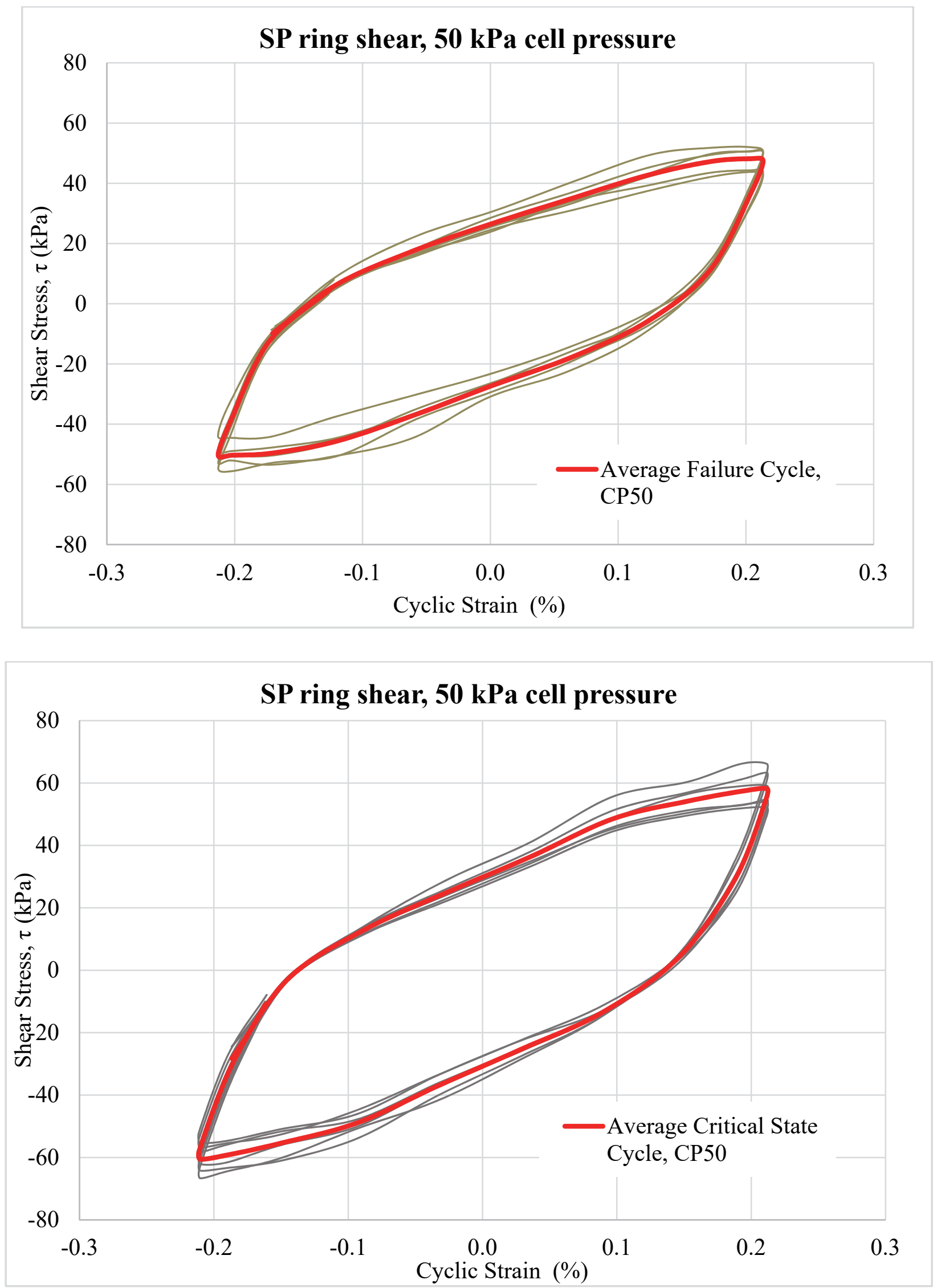

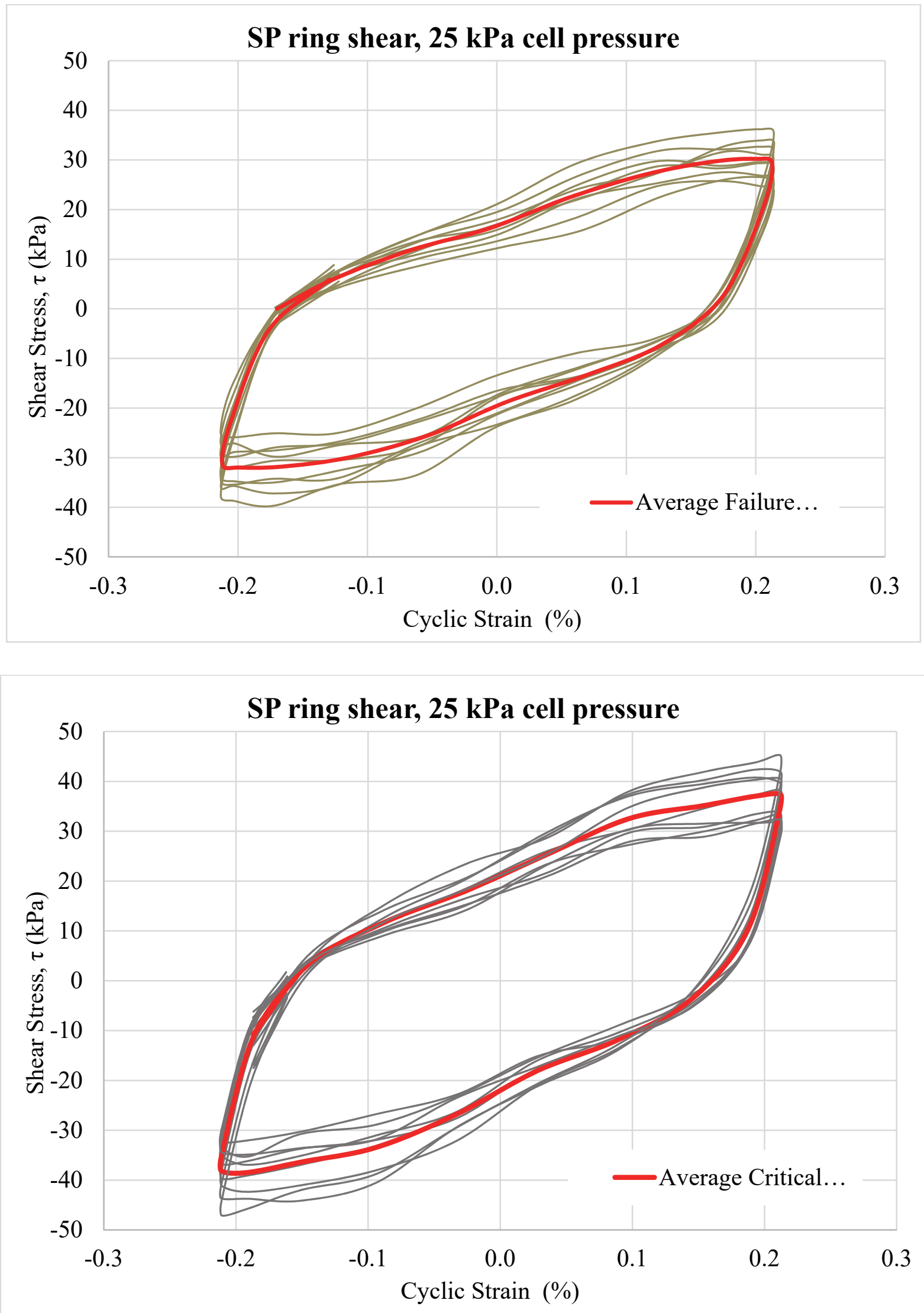

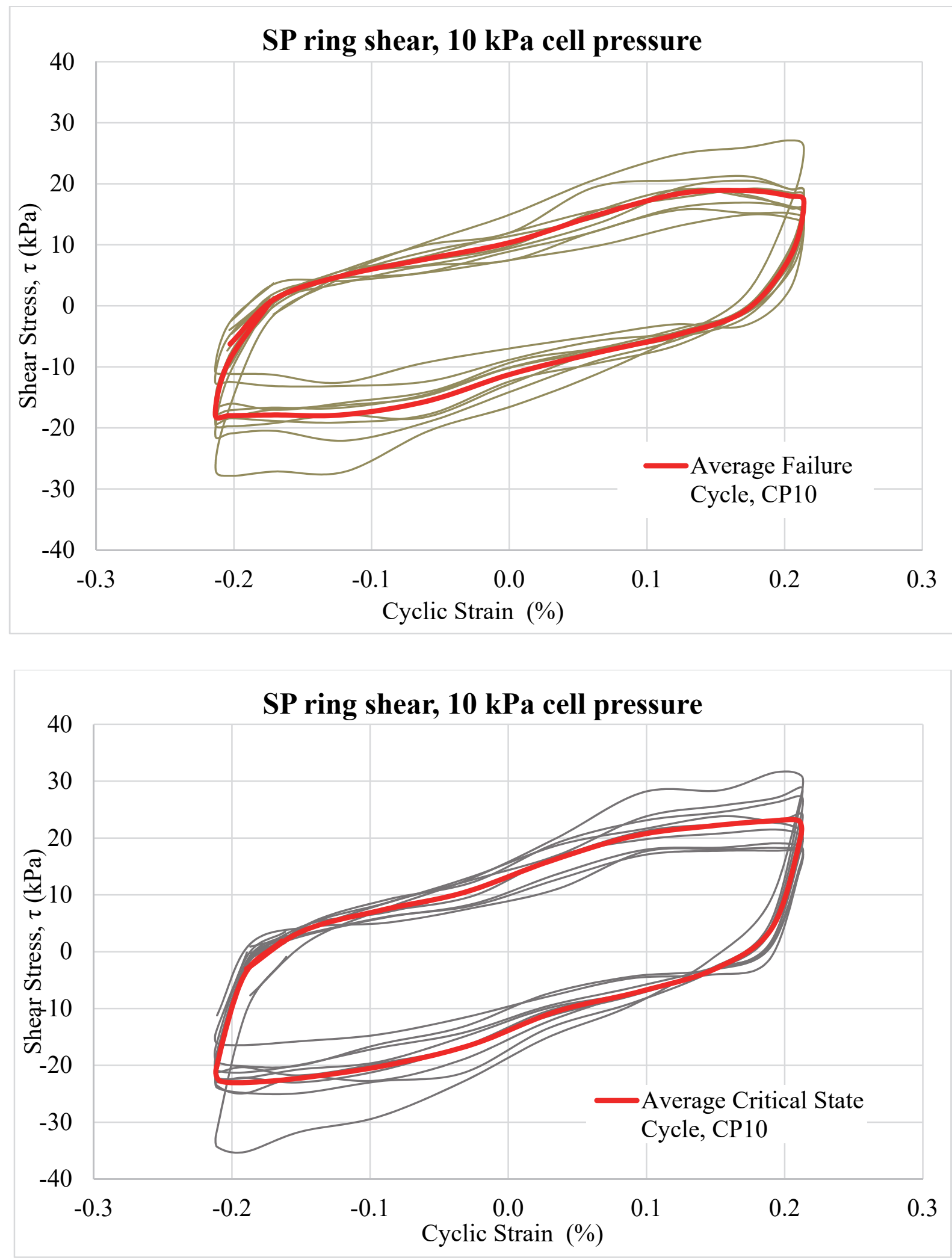


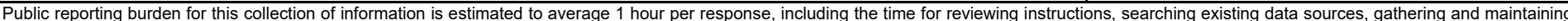

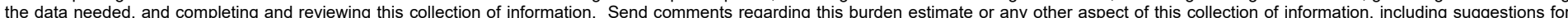

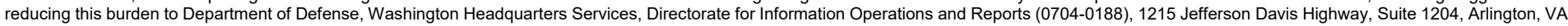

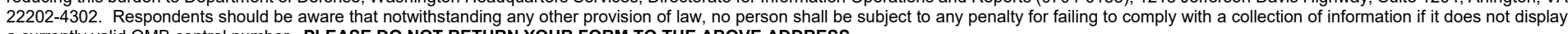
a currently valid OMB control number. PLEASE DO NOT RETURN YOUR FORM TO THE ABOVE ADDRESS.
1. REPORT DATE (DD-MM-YYYY)
2. REPORT TYPE
3. DATES COVERED (From - To)

August 2018

Final report

\section{TITLE AND SUBTITLE}

5a. CONTRACT NUMBER

Laboratory Investigations of Cohesionless Shear Strength in Low Confinement

Environments

\section{5b. GRANT NUMBER}

5c. PROGRAM ELEMENT NUMBER

\section{AUTHOR(S)}

Katherine E. Winters, Oliver-Denzil S. Taylor, Woodman W. Berry, Amy L. Cunningham,

Wesley R. Rowland, and Mark D. Antwine

\section{5d. PROJECT NUMBER}

458272

5e. TASK NUMBER

5f. WORK UNIT NUMBER

\section{PERFORMING ORGANIZATION NAME(S) AND ADDRESS(ES)}

U.S. Army Engineer Research and Development Center

Geotechnical and Structures Laboratory

3909 Halls Ferry Road

Vicksburg, MS 39180-6199

\section{SPONSORING / MONITORING AGENCY NAME(S) AND ADDRESS(ES)}

Headquarters, U.S. Army Corps of Engineers

Washington DC 20314-1000
8. PERFORMING ORGANIZATION REPORT NUMBER

ERDC/GSL TR-18-22

10. SPONSOR/MONITOR'S ACRONYM(S)

11. SPONSOR/MONITOR'S REPORT NUMBER(S)

\section{DISTRIBUTION / AVAILABILITY STATEMENT}

Approved for public release; distribution is unlimited.

\section{SUPPLEMENTARY NOTES}

\section{ABSTRACT}

In low-confining stress environments, Mohr-Coulomb failure mechanics implies that a cohesionless soil has negligible shear strength. This report presents results of total stress laboratory investigations from triaxial and simple shear loadings for three loose- to mediumdense, cohesionless materials, i.e., a poorly-graded sand (SP), a silty sand (SM), and a silt (ML), at confining pressures ranging from zero to $1000 \mathrm{kPa}$, as well as cyclic ring shear testing of the SP material at confining pressures from 10 to $100 \mathrm{kPa}$. All materials exhibited shear strengths and stress paths in excess of expected failure surfaces at confining pressures under $100 \mathrm{kPa}$. The data indicate that cohesionless soils exhibit significant soil fabric strength characteristics that are not captured by the standard internal friction angle definition, as evidenced by the shear stress intercept of the trendlines relating shear strength and confining pressure. Under low confinement, the continuum fabric dominates the angle of the Mohr envelope. The significant difference in the Mohr envelope shape illustrates that the internal fabric's ability to resist different loading mechanisms cannot be assumed by a linear approximation.

\begin{tabular}{lll}
\hline 15. SUBJECT TERMS & Soil fabric & Shear strength of soils-Testing \\
Laboratory testing & Soil mechanics & Sandy soils \\
Low confinement & Shear strength & Soil erosion
\end{tabular}

\begin{tabular}{|l|c|c|c|l|l|}
\hline \multicolumn{2}{|l|}{ 16. SECURITY CLASSIFICATION OF: } & $\begin{array}{l}\text { 17. LIMITATION } \\
\text { OF ABSTRACT }\end{array}$ & $\begin{array}{l}\text { 18. NUMBER } \\
\text { OF PAGES }\end{array}$ & $\begin{array}{l}\text { 19a. NAME OF RESPONSIBLE } \\
\text { PERSON }\end{array}$ \\
\cline { 1 - 2 } $\begin{array}{l}\text { a. REPORT } \\
\text { UNCLASSIFIED }\end{array}$ & $\begin{array}{l}\text { b. ABSTRACT } \\
\text { UNCLASSIFIED }\end{array}$ & $\begin{array}{l}\text { c. THIS PAGE } \\
\text { UNCLASSIFIED }\end{array}$ & SAR & 76 & $\begin{array}{l}\text { 19b. TELEPHONE NUMBER (include } \\
\text { area code) }\end{array}$ \\
\end{tabular}

